\title{
Museu Sertório: uma coleção particular em São Paulo no final do século XIX (primeiro acervo do Museu Paulista)'
}

\begin{abstract}
Paula Carolina de Andrade Carvalho ${ }^{2}$
RESUMO: Este artigo pretende rastrear e recuperar a coleção particular conhecida como Museu Sertório, que, embora tenha se constituído como o primeiro núcleo do acervo do Museu Paulista, é um tema ainda pouco explorado na historiografia. De propriedade do coronel Joaquim Sertório, a coleção tornou-se um museu privado na cidade de São Paulo, ganhando relevância na segunda metade do século XIX. As peças a ele pertencentes foram doadas ao governo paulista em 1890, tornando-se o embrião do acervo do Museu Paulista, que viria a ser inaugurado, em 1895, no Monumento do lpiranga.

PALAVRAS-CHAVE: Museu Sertório. Coronel Joaquim Sertório. Museu Paulista. Coleções.

ABSTRACT: This research intends to trace and recover information about the private collection known as Museu Sertorio, which became Museu Paulista's first main collection. This subject matter hasn't been bestowed upon it by the specialized historiography. This collection, a private museum in São Paulo, belonged to Colonel Joaquim Sertorio, and it became famous in the second half of the 19th century. This museum was donated to São Paulo estate government in 1890, from which Museu Paulista was created; it officialy opened in 1895 at the lpiranga Monument. KEYWORDS: Museu Sertorio. Colonel Joaquim Sertorio. Museu Paulista. Collections.
\end{abstract}

Esta pesquisa situa-se no campo de estudos da História da Cultura, mais especificamente da História da Cultura Material, voltada para o fenômeno do colecionismo, área cujo interesse acadêmico vem crescendo ao longo das últimas décadas. Segundo Peter Burke, esse

(...) interesse pelos colecionadores e os especialistas faz parte de uma evolução geral que envolve várias disciplinas, uma passagem do ato criativo ou da produção para a recepção, o consumo; dos autores para os leitores; dos atores e dos artistas para os espectadores ${ }^{3}$.
1. Este artigo é resultado de pesquisa de iniciação científica desenvolvida no Museu Paulista da USP, sob orientação da profa. dra. Heloisa Maria Silveira Barbuy, com apoio da Fundação de Amparo à Pesquisa do Estado de São Paulo (Fapesp).

2. Historiadora, bacharel em História pela FFLCH/ USP. E-mail: <paula_carva1ho33@yahoo.com.br>.

3. Cf. Peter Burke (2005, p. 51) 
4. O Museu Paulista abriu com as coleções Sertório e Pessanha e outras aquisições realizadas para completar o acervo já existente, como a compra de uma coleção de ovos de pássaros de Ricardo Krone (Recibo do Museu Paulista a Ricardo Krone em Iguape. 06 fev. 1895. Fundo Museu Paulista, Série Prestação de Contas. Pasta 31) ou a entrega de répteis vindos de um museu de História Natural, de Halle, na Alemanha (Recibo a Wilhelm Schlüter, do Naturhistorisches Institut. 31 jan. 1895. Fundo Museu Paulista, Série Prestação de Contas. Pasta 31), entre outros

5. Ver Maria Margaret Lopes (1997).

6. Ver Ana Maria de Alencar Alves (2001); Diego Amorim Grola (2014); Maria Margaret Lopes e Silvia Figueirôa (2003); Fabio Rodrigo Moraes (2008); Lilia Schwarcz, (2007, [1993]).

7. Ver Ana Maria de Alencar Alves, (2001); Ana Claudia Brefe (2005); Maria José Elias (1996); Nicolau Sevcenko (1990).

8. Ver Mariana Françozo (2005).

9. Ver Tathianni Cristini da Silva (2014).

10. Cf. Maria Margaret Lopes (1997, p. 12-13).

11. Cf. Antoine Schnapper (1988, p. 9).

12. Ver Adalgisa Lugli (apud Antoine Schnapper, 1988).

13. Essa palavra toma a forma de meraviglia, em italiano, merveille, em francês, e Wünder, em alemão (de onde se origina o termo Wünderkammer, ou "gabinete de maravilhas").
No contexto brasileiro, a coleção Sertório estava associada à formação do núcleo inicial do primeiro acervo do Museu Paulista ${ }^{4}$, que se configurou como um museu de História Natural - portanto, vinculando-se diretamente ao movimento de criação dos museus no país, conforme esclarecido por Maria Margaret Lopes ${ }^{5}$. Esta pesquisa visa contribuir com dados mais sólidos sobre a coleção Sertório na esteira dos estudos atuais sobre o tema.

Nas últimas décadas, diversos trabalhos foram redigidos sobre o Museu Paulista, alguns tendo como ponto central a administração de Hermann von Ihering e a História Naturalo, outros voltados para a gestão de Affonso Taunay ${ }^{7}$, momento em que se tornou preponderantemente museu de História, assim como para as gestões de Sérgio Buarque de Holanda (1946-1956) e Mário Neme (1960-197319. O Brasil descobre a pesquisa científica, de Maria Margaret Lopes, é o principal livro de referência sobre o assunto, abordando o início da criação dos museus brasileiros, inclusive o Museu Paulista, com foco na institucionalização das ciências naturais no país no final do século XIX e com ênfase no Museu Nacional do Rio de Janeiro. A tese de doutorado de Maria José Elias, Museu Paulista: memória e história, mesmo se concentrando no caráter institucional do Museu Paulista e não nas suas exposições e coleções, tratou brevemente dessas origens. O Ipiranga apropriado: ciência, política e poder lo Museu Paulista 1893-1922), de Ana Maria Alencar Alves, abordou o período inicial do Museu Paulista, passando pela administração de Hermann von Ihering até os primeiros anos de Affonso Taunay no comando da instituição. Em $O$ espetáculo das raças, Lilia Moritz Schwarcz estudou o Museu Paulista sob a direção de lhering pela chave das teorias raciais, caracterizando a instituição como um "museu etnográfico". O artigo "Uma coleção de história em um museu de ciências naturais: o Museu Paulista de Hermann von thering", de Fábio Rodrigo de Moraes, tratou sumariamente da coleção Sertório como núcleo de origem do Museu Paulista.

Com isso, percebe-se que a composição inicial do acervo do Museu Paulista ainda não foi objeto específico de nenhum estudo. $\bigcirc$ que se propõe no presente artigo é avançar na compreensão do Museu Sertório, que era uma coleção particular, pertencente ao coronel Joaquim Sertório, reunida no fim do século XIX em São Paulo.

Sobre as origens dos museus, explica Maria Margaret Lopes que estão associadas ao fenômeno do colecionismo, consolidado com os gabinetes renascentistas e com uma nova atitude europeia diante do passado, das partes desconhecidas do mundo, da natureza, ou seja, diante do "invisível":

As viagens que se multiplicam a partir do século XV deslocam as fronteiras do invisível e atingem locais até então impensados, levando dos novos mundos para os gabinetes dos príncipes e sábios não só mercadorias altamente lucrativas, mas também todo um novo saber. Tecidos, ourivesarias, porcelanas, fatos de plumas, estátuas, cerâmicas, exemplares da flora e da fauna, conchas (...), objetos que, retirados de seu contexto e recolhi- 
dos não pelo seu valor de uso, mas por seu significado, perderam utilidade, passando a representar o invisível: países exóticos, sociedades diferentes, outros climas ${ }^{10}$.

Era esse o caráter dos objetos encontrados na coleção Sertório, sendo bastante similar ao modelo de gabinete de curiosidades europeu da época moderna. Segundo Antoine Schnapper (a partir de estudo feito por J. von Schlosser), as coleções dos gabinetes assumiam comumente a forma de um microcosmo,

não apenas no sentido antigo do termo, que designava o homem em relação ao macrocosmo natural, mas também no sentido de resumir o mundo, onde haveria espaço para os objetos da terra, do mar e do ar, ou dos três reinos, mineral, vegetal e animal, ao lado de objetos feitos pelo homem ${ }^{11}$.

Adalgisa Lugli propôs que a metáfora do gabinete como resumo do mundo fosse tomada ao pé da letra ${ }^{12}$, em referência às técnicas da ars memoriae, retiradas de um tratado de 1565, do médico flamengo Samuel Quiccheberg, que forneceu os princípios de classificação os quais, mais tarde, seriam encontrados nos gabinetes de curiosidades, opondo objetos naturais aos artificiais. Essas classificações seriam utilizadas nos gabinetes de príncipes com o fim de montar-se um museu enciclopédico, que colocaria sob os olhos do espectador, em uma ordem didática, os objetos. Entretanto, os gabinetes não procuravam conter todas as coisas existentes por meio da coleta exaustiva de quaisquer objetos; ao contrário, esse resumo do mundo era representado pela escolha dos elementos mais significativos, como uma forma de mostrar a riqueza e a unidade da criação divina. Havia um gosto pelo monstruoso e o estranho, assim como pelos pontos de interesecção entre os reinos animal, vegetal e mineral, como fósseis e petrificações.

Esse momento pelo qual passava a Europa foi chamado por Joy Kenseth de "era das maravilhas", e se refletiu no interesse crescente por tudo que fosse raro ou incomum. Durante os séculos XVI, XVII e XVIII, o termo "maravilha"13, referia-se a qualquer coisa que causasse espanto, assombro, surpresa ou admiração, e a capacidade de causar maravilhamento também era considerada um valor em si. Esse fenômeno surgiv e se difundiu em um período marcado por uma mudança de mentalidade europeia, na transição da Idade Média para a Idade Moderna. Assistia-se simultaneamente ao enfraquecimento de uma visão predominantemente religiosa e o despertar de um interesse científico e humanista, e à redescoberta de artefatos, a arte e os textos da Antiguidade greco-romana, que demonstravam gosto pelo maravilhoso. Ao interpretar essas características dos antigos, a sociedade renascentista ressignificou os fundamentos do maravilhoso.

O descobrimento da América e a exploração de outros mundos pouco conhecidos para o homem medieval, como a África e o Oriente, também despertou interesse pelo maravilhoso. $O$ comércio de objetos (tanto naturais quanto de fabricação humana) originários dessas terras distantes foi responsável por um efeito

Annals of Museu Paulista. v. 22. n.2. Jul.-Dec. 2014. 
14. Ver Joy Kenseth (1991).

15. Idem.

16. Aqui é pertinente citar Krzysztof Pomian que procurou, em estudo de 1978, determinar o que tinham em comum os objetos naturais e artificiais colecionados pelo homem desde a pré-história: seriam todos "semióforos", objetos que não têm utilidade prática, mas que representam o invisível e, por isso, dotados de significado - em contraponto, existem as "coisas", objetos úteis que ajudam o homem a transformar a natureza. Os "semióforos" são os objetos que compõem uma coleção que, para Pomian, consiste em um conjunto de objetos naturais ou artificiais, mantidos em caráter temporário ou permanente fora do circuito de atividades econômicas, sendo isolados em um espaço fechado criado para tal, mas onde são expostos ao olhar. Para Antoine Schnapper, essa definição de coleção seria, para um historiador, ao mesmo tempo, muito geral e muito restrita: muito geral porque, dessa forma, é possível incluir qualquer acumulação de objetos, como os tesouros de igrejas, que são os ancestrais das coleções; e muito restrita diante do conceito de "espaço fechado criado para tal” - embora a não participação dos circuitos econômicos seja um critério dessa categoria. Apesar de essa divisão ser importante para separar o colecionador puro - que guarda suas melhores peças dentro de um quarto, de um gabinete, ou de uma galeria daqueles que, por exemplo, possuem obras de arte para decorar a casa, "não se deve isolar as funções de coleção e de decoração como se fossem corpos químicos puros. É raro encontrar em inventários post mortem ou nas descrições das coleções, mais forte do que relatos escritos ou ouvidos, uma vez que eram elementos reais e palpáveis, e, portanto, "fatos observáveis". Colecionadores europeus buscavam avidamente pelos artefatos exóticos com o intuito de serem orgulhosamente reunidos em museus e gabinetes de curiosidades ${ }^{14}$.

Outro fator a alimentar essa voga na Europa foram os grandes avanços científicos e tecnológicos, com invenções como o telescópio e o microscópio. A própria filosofia da ciência passaria por mudanças ao adotar a escola baconiana, que preconizava a observação, a experimentação e a demonstração na prática da ciência. $\bigcirc$ maravilhoso estaria assim intimamente ligado ao espetacular, com efeitos ilusionísticos não só em performances teatrais, mas também em exibições de fontes de jardins, exposições de autômatos e outras apresentações que tinham por objetivo surpreender os espectadores ${ }^{15}$.

Mas, a partir dos anos 1700, a cultura do maravilhoso já dava sinais de esgotamento diante da proliferação dos gabinetes de curiosidades pela Europa: paradoxalmente, à medida que eles se popularizavam, perdiam a capacidade de causar maravilhamento. $\bigcirc$ maravilhoso tornara-se lugar-comum. Ao mesmo tempo, o pensamento científico caminhava na superação do imaginativo, e os antes considerados prodígios divinos passaram cada vez mais a ganhar uma explicação racional. Nesse sentido, com a difusão do racionalismo, o olhar sobre o mundo foi perdendo sua magia.

Mesmo assim, é interessante perceber as permanências ao longo dos processos históricos na perspectiva de longa duração. No caso específico do Museu Sertório e suas coleções, o modelo do gabinete de curiosidades da Europa moderna encontrou ecos na São Paulo do século XIX, momento em que os museus nacionais do Novo Mundo estavam sendo organizados.

Uma das principais características para comprovar as permanências no mundo do colecionismo, no caso examinado, é a presença de uma série de peças $^{16}$ que encontraram espaço tanto nas coleções dos gabinetes europeus dos séculos XVI e XVII quanto no Museu Sertório na São Paulo do século XIX. Isso pode ser depreendido a partir de descrições da coleção Sertório encontradas na imprensa e em relatos de viajantes. Ao visitar o Museu Sertório em 1881, o botânico sueco Alberto Loefgren ${ }^{17}$ procurou descrever o que viu ${ }^{18}$ :

Aí [no Museu Sertório] vimos o maior dos roedores existentes, tão daninho à lavoura, a capivara - "Hydrochoerus capibara" L. e a paca, "Coelogenys paca", L. também roedor de profissão: O quati - "Nasua socialis" Pr: Max: o único representante dos ursos no Brasil, como se vê pelo andar deste animal, que é no pé inteiro. A lontra - "Lutra vulgaris". Erxl: o intrépido caçador de peixes. A onça - "Felix onça" L. O tamanduá -"myrmecophaga jubata" L., a preguiça - "Bradypus tridactilus" L. e os tatus - "Dasipus" [sic], das variedades "peba, longicaudatus e novencinctus [sic]". Os monos "mycetes" e os micos - "Ateles" aí se acham em companhia de uma imensidade de outros quadrúpedes.

De pássaros notamos uma grande variedade, desde o silencioso e filosófico jaburu "Mycteria americana" L., até os pequenos e ligeiros beija-flores - "Trochilus pella, coli- 
bris, mosquitos e minimus" L. com suas deslumbrantes cores, passando pelas águias "Aquila", Araras - "Cacatus", papagaios - "Psicatus", pica-paus - "Picus". Uma bela coleção de corvjas - "Strix, Ululas e Surnias".

Grande variedade de galináceos: o jucu [sic] - "Penelope cristada", a perdiz - "Perdrix cinérea" L. e até a linda ave do paraíso - "Paradisea apoda", assim chamada porque, quando pousada, seus pés ficam escondidos pela magnífica plumagem.

Entre os anfíbios notamos os jacarés - "crocodilus"; tartarugas - "Testudinata"; grande cópia de cobras - "ophidiae" e rãs - "Batrachia". Pode-se aí examinar sem perigo os horríveis dentes da cascavel - "Crotatus horridus" L.

De insetos, uma prodigiosa quantidade. Belíssimos quadros de borboletas onde podemos em um lance de olhos ver as mais belas que a terra possui. Também lindos quadros de ovos, de um alto valor. Na mesma sala ainda admiramos as esquisitas formas da lagosta - "Palinurus" F. e o horrendo feitio da grande aranha - "Mygale", de nossas matas.

Grande variedade de belíssimos corais, assim como de caramujos e conchas, sobressaindo entre estas a concha da pérola - "Meleagrina margaritifera" L., dos mares da Síria.

Em pedras, variadíssimos espécimes, desde o granito até o diamante: Ágates, cristais e metais, entre estes uma bonita pedra com ouro nativo. Os espécimes de madeiras do país são em avultado número.

Notamos ainda uma grande coleção numismática, contendo perto de duas mil moedas e medal has de todos os países e muitas delas com 300 a 400 anos de antiguidade.

Alguns objetos de países longínquos, como pedaços de oliveira da terra Santa e a curiosa rosa de Jericó - "Anastarthica hierocunthia" [sic] e belos trabalhos de conchas.

Em vista de tudo isto não podemos deixar de aplaudir a perseverança do sr. coronel Sertório.

O seu exemplo terá talvez no futuro imitadores e desde que o gosto de colecionar se manifeste, de perto o seguirá o amor ao estudo das ciências naturais tão interessante e tão útil 19 .

Essa é, provavelmente, a primeira descrição do Museu Sertório a ser publicada na imprensa, tendo autoria de Loefgren, que veio a se tornar o primeiro diretor do Museu do Estado assim que a coleção Sertório foi doada para o governo paulista. Já nesse relato percebe-se a variedade de objetos do museu advindos do reino animal, vegetal e mineral, e, em especial, como alguns deles podiam igualmente ser encontrados nos gabinetes europeus ${ }^{20}$ :- o corall ${ }^{21}$, conchas com pérolas (caso da Meleagrina margaritifera dos mares da Síria) ${ }^{22}$, a rosa de Jericó ${ }^{23}$, o tatu ${ }^{24}$ e a ave do paraíso ${ }^{25}$. $\bigcirc$ jornalista carioca Ezequiel Freire também escreveu sobre a coleção Sertório, em 1882 :

(...) essas coleções são tão variadas e completas que constituem verdadeiro museu, superior em certos pontos ao Museu Nacional [situado no Rio de Janeiro], segundo a opinião de alguns estrangeiros que têm visitado ambos e puderam estabelecer confronto 26 as peças que claramente foram reunidas para fazer parte de uma coleção. Mesmo os colecionadores célebres possuíam obras de arte de grande valor distribuídas por quase toda a sua residência. E ainda há o caso dos colecionadores de objetos efêmeros, como flores e frutos (...)", cf. Antoine Schnapper (1988, p. 8). Mesmo com essa ressalva em relação ao estudo de Pomian, Schnapper adotou a categoria de semióforo em sua análise das coleções francesas do século XVII: "A partir da Renascença duas categorias de semióforos ganham espaço em primeiro plano ao lado das obras de arte: as antiguidades e os objetos exóticos, que são trazidos pelos marinheiros e os viajantes, e que compõem o conjunto de curiosidades naturais. Todos esses objetos se relacionam, para usar uma expressão daquele tempo, à História e à História Natural" Ibidem.

17. Essa será a grafia adotada para o nome de Alberto Loefgren neste trabalho, uma vez que era dessa forma que o próprio cientista assinava seu nome. Outras grafias encontradas foram: "Alberto Loefgreen", "Alberto Lofgren", "Alberto Loeffgreen" e "dr. Leffgreen".

18. Nas citações de notícias de jornal, procurou-se seguir a formatação dos jornais da época, dando destaque a títulos ou subtítulos, além de mostrar palavras em itálico quando o próprio jornal formatavaas dessa maneira; a grafia da época foi atualizada para os padrões atuais.

19. Cf. Correio Paulistano (19 nov. 1881, p. 1).

20. Essa parte da pesquisa foi calcada no estudo realizado por Antoine Schnnaper (1988) sobre as coleções francesas no século XVII. 
21. O coral poderia ser encontrado nos gabinetes em forma de pó ou colorido após tingimento, sendo muito utilizado como fortificante, e levado como amuleto para trazer boa sorte.

22. As pérolas eram consideradas as "pedras preciosas mais comuns. Os colecionadores tinham grande interesse em encontrar uma que estivesse ainda ligada à sua ostramãe.

24. O tatu (antigamente classificado como réptil e não como mamífero) era popular nos gabinetes: para além de sua aparência bizarra, a solidez de sua pele ajudava no processo de conservação, em uma época em que os animais empalhados ou grosseiramente embalsamados costumavam ser presas fáceis dos vermes e, por isso, se desintegravam.

25. Era a espécie de ave mais corrente nos gabinetes, pois sua penugem esplêndida encantava os colecionadores. Segundo histórias contadas no século $\mathrm{XV}$, a ave do paraíso seria uma espécie de pássaro ápoda, ou seja, sem patas, ou pássaro sem asas que, devido à sua longa plumagem, poderia voar caso houvesse vento, além de se nutrir de orvalho. Contava-se que o macho possuía as costas ocas, onde a fêmea depositava os ovos, por isso o interesse dos colecionadores em adquirir um macho e uma fêmea para os gabinetes. A origem desses relatos veio dos costumes dos indígenas das ilhas Molucas, que vendiam os restos de aves mutiladas, após remover suas patas, assim como as asas e a cabeça, talvez para elevar o valor da plumagem. Já no século XVI, entretanto, esses relatos passaram a ser questionados.
Mui curiosas se tornam as coleções de animais, por constarem quase exclusivamente de representantes da fauna paulista. Entre mais de mil pássaros, notam-se os belos grupos completos de pássaros verdes, de pica-paus, um de corvjas, outro de gaviões, desde o gavião pardo muito conhecido nas fazendas, onde faz guerra de morte aos pintainhos implumes, até o enorme gavião-pato, a águia brasileira.

Na tribo das columbinas distinguimos, como o mais raro e curioso exemplar, a pomba verde da qual lembro-me ter ouvido dizer que é espécie extinta, na opinião de Darwin.

Os quadrúmanos estão bem representados, desde o pequeno sagui lépido e petulante, até o grande mono pesado e circunspecto, podendo os transformistas lá ir tomar a benção aos avós empalhados do gênero-humano.

(...) na mesma vidraça, podem casualmente encontrar-se reunidos indivíduos dos mais disparatados feitios e índole: - uma tartaruga ao lado de um beija-flor, de um cristal de quartzo, ou de uma espada histórica.

Naquelas coleções há de tudo, raridades, curiosidades e monstruosidades de toda sorte: um serpentão antiquíssimo, instrumento de música, feito de sola, de feitio singularíssimo, - uma espada que pertenceu ao brigadeiro Tobias, - um aparelho de fiar, que foi de D. Clara Maria do Amador Bueno, neta de Amador Bueno, e data, pelo menos, de 1730 .

Além destas velharias curiosas, muitas outras, amuletos, fetiches de índios, artefatos indígenas, monstros vegetais e animais, coleções de conchas, mineralógicas, numismáticas, - de madeiras, de insetos e até de jornais! ${ }^{27}$.

A visão de Freire tem um viés claramente paulista, pois logo no início, ele chama a atenção para comparações feitas por visitantes estrangeiros entre o Museu Sertório e o Museu Nacional, segundo as quais o estabelecimento paulista chegava a ser, em certos pontos, "superior" ao outro.

Seria essa uma forma encontrada pelo jornalista de alfinetar a instituição de origem imperial, evidenciando que a capital paulista também possuía um museu respeitado e, portanto, inserindo São Paulo como um dos importantes centros da civilização brasileira ao lado do Rio de Janeiro? Logo em seguida, elogia o fato de quase todas as coleções de animais serem formadas por espécies da fauna paulista. Freire ainda se mostra fascinado pela coleção de pássaros e de primatas nota-se que, quando tece comentários sobre ambas, menciona com naturalidade Charles Darwin e sua teoria da evolução das espécies (ao se referir a macacos empalhados como "avós do gênero humano"), exibindo sua própria familiaridade com as ciências. Essa descrição também salienta a presença de monstruosidades vegetais e animais, objetos obrigatórios nos gabinetes de curiosidade europeus, em meio a peças históricas. Como no relato de Loefgren, Freire descreve a organização do museu como caótica, em que diferentes tipologias de peças dividem o mesmo espaço expositor.

Em 1883, o político e jornalista alemão Carl von Koseritz, residente em Porto Alegre, em visita a São Paulo, foi conhecer o museu do Coronel Sertório a convite de seu amigo Alberto Loefgren. Ele não poupou elogios ao acervo, afirmando que "excedeu" suas expectativas, sendo uma realização inigualada por 
"nenhum particular no Brasil", ao constituir "um museu como nenhuma província do país possui" e de "valor muito grande"28. Koseritz ainda fez uma descrição sintética da coleção:

A seção ornitológica possui todos os pássaros do sul do Brasil em ótimos exemplares. A seção zoológica possui também a maior parte dos quadrúpedes brasileiros em exemplares igualmente excelentes. A coleção de moluscos é extremamente rica e possui notadamente ostras de pérolas em grande profusão e de surpreendente beleza. Igualmente ricas e bem organizadas são as seções mineralógica e botânica (...) A coleção de peixes e répteis é da mesma forma muito abundante mas, ao contrário, a coleção antropológica não é muito valiosa, pois só possui um esqueleto de mulher preparado na Europa e alguns crânios comuns. Nada há sobre o homem americano, nem crânios ou ossos dos sambaquis, nem tampouco ossos das cavernas. (...) A coleção etnográfica contém poucas armas de pedra, urnas e potes, mas possui, em compensação, muitos objetos de uso dos indígenas atuais, que são muito interessantes. A coleção de moedas é bem coordenada e tem exemplares raros; é de importância considerável. Ao lado se vê uma coleção de jornais brasileiros, quadros, gravuras e litografias, também muito interessante. $\bigcirc$ "Museu do major (sic) Sertório" é rico em curiosidades. Ali estão as disciplinas (instrumentos de flagelação) dos velhos conventos de São Paulo; uma camisa, uma toalha e cartas de Solano López; a espada ornada de ouro do general Tobias; uma espada de couraceiro do campo de batalha de Sedan; uma grande coleção de velhas, novas e novíssimas armas de fogo; velhos floretes de Toledo; um assento de honra que serviu a D. Pedro I em São Paulo, além de uma quantidade de outras coisas como fetos, petrificações, ovos de pedra etc. ${ }^{29}$.

relato de Koseritz destaca outras coleções que não as de ciências naturais, sobre as quais faz breves comentários - como na narrativa de Loefgren, as conchas com pérolas são dignas de menção. Mesmo assim, seu foco está voltado para as coleções de cunho antropológico lque são alvo de crítica pela falta de peças sobre as populações que viveram na região de São Paulo durante o período pré-histórico), etnológico (que têm seu valor pela grande quantidade de objetos indígenas) e histórico (as quais ele chama de "curiosidades", como o assento em que se sentou D. Pedro I - ao narrar o fim da visita, Koseritz afirma que Sertório tomou um copo de cerveja fresca sentado nesse trono! ${ }^{30}$ ). Chama a atenção ainda para a presença de uma coleção de jornais (já evidenciada por Freire), e de objetos artísticos, como quadros e gravuras, assim como peças insólitas (fetos e petrificações).

$\bigcirc$ médico italiano Alfonso Lomonaco também exaltou a riqueza do museu, quando o visitou em 1886 :

Aqui [no Museu Sertório] se encontra um pouco de tudo: das mais belas coleções zoológicas e mineralógicas locais até o mais rico acervo de moedas que faria a felicidade de um numismata. Há também uma coleção de pássaros e conchas do Brasil que me pareceu belíssima. Ainda se descobre uma coleção de ornamentos, utensílios e armas de índios e objetos preciosos e raros bem valiosos, (...) o que o torna um dos museus privados mais ricos que já vi ${ }^{31}$.
26. Desconheço a quais relatos Ezequiel Freire se refere, pois a primeira descrição de uma visita ao Museu Sertório com a qual me deparei foi a de Loefgren, que está transcrita no início do trabalho. Os relatos de outras visitas, além de serem posteriores a 1882 (ano em que essa notícia foi veiculada no jornal), não fazem menção ao Museu Nacional. O jornalista alemão Carl von Koseritz também visitou o Museu Nacional, mas em 1883, um ano depois da publicação da notícia de Freire. No entanto, é interessante observar que na inauguração do Museu Paulista, em 1895, já existia uma rivalidade entre as duas instituições. O discurso proferido por Hermann von Ihering menciona que, com a abertura do Museu Paulista, foi inaugurado "um museu sobre bases realmente científicas como até agora no Brasil não existiu", ignorando peremptoriamente a existência anterior do Museu Nacional. Para saber mais, ver Maria Margaret Lopes (1997) e Fábio Rodrigo Moraes (2008).

27. Cf. Correio Paulistano (27 set. 1882, p. 2).

28. Cf. Carl von Koseritz (1980 [1883], p. 265-266)

29. Idem (p. 266-267).

30. Ibidem

31. Cf. Alfonso Lomonaco (1889, p. 121-122). É importante observar que Lomonaco visitou o Museu Sertório em 1886, entretanto o seu relato só foi publicado em 1889. 
Lomonaco foi, por sua vez, mais econômico na sua narrativa, mas ressaltou o que, a seu ver, eram os pontos fortes do museu: as coleções de moedas, pássaros e conchas.

Em Alguns dias na Pauliceia, o cronista Henrique Raffard, além de recomendar a visita ao Museu Sertório, fez uma descrição bem detalhada das coleções, de sua organização e do estado de conservação de algumas peças. Apesar de longo, é um registro importante para se ter uma ideia da conformação do museu e do seu caráter de miscelânea, elemento essencial do gabinete de curiosidades:

Naquele [o salão do pavimento inferior] admirei muitas armas dos nossos indígenas, vestimentas e enfeites das tribos amazonianas, urnas funerárias (caçabas), crânios de Carijós e outros, sambaquis, conchas e mais coisas do mar, pedaços de xistos com fósseis, madeiras petrificadas, coleção de madeiras do país, matérias têxteis; inúmeras amostras mineralógicas, borboletas, insetos, répteis, bichos e aves empalhadas, algumas mandadas vir da Europa, outras obtidas do Jardim Público de S. Paulo (...)

Certas peças acham-se completamente estragadas, não tendo sido convenientemente preparadas; outras melhor conservadas não têm as formas naturais, v.g. a girafa, o cavalo, a leoa, etc. (...)

Chegando ao salão do segundo andar, depara-se logo com uma grande tela pintada a óleo representando o Sr. D. Pedro II de tamanho natural nos trajos em que se apresentava na abertura das câmaras; num canto lê-se o nome do autor, F.R. Moreau, e data do trabalho, 1849. Sobre o quadro foi colocada uma etiqueta com a seguinte inscrição:

MUSEU SERTÓRIO - Retrato do ex-Imperador D. Pedro II, esteve no palácio do Governo de São Paulo até o dia 15 de Novembro de 1889, data da proclamação da República dos Estados Unidos do Brasil.

Atravessando a imagem do corpo do grande príncipe, acha-se escrito a lápis vermetho: Viva a República, e ao lado, com uma faca ou canivete, foram feitos verticalmente a uns 15 centímetros de distância dois rasgos paralelos de mais ou menos 1 metro e 40 centímetros.

Continuando meu exame, prendeu minha atenção um pequeno quadro no qual está apensa uma bala de revólver ao documento que passo a transcrever aqui:

"Na cabeça do papel - de um lado: Consultório 74 A, Rua da Quitanda, esquina da Rua do Rosário, 1, às 3 horas da tarde. Residência Rua de Rezende, 114 - do outro lado: Clínica do Dr. José Pereira Guimarães, operador, lente catedrático de Anatomia descritiva da Faculdade de Medicina do Rio de Janeiro, operações, tratamentos da uretra, moléstias venéreas, etc.; Typ. Laemmert, Inválidos, e em seguida: $\bigcirc$ Dr. José Pereira Guimarães, lente catedrático da Escola de Medicina do Rio de Janeiro, etc. Atesto que entreguei ao Dr. Ângelo Pires Ramos uma das balas por mim extraídas do ex-Ministro da Marinha, vice-almirante Barão do Ladário.

Esse corpo estranho foi retirado da parte interna da articulação do joelho esquerdo e penetrou ao nível da porção inferior e externa da coxa do mesmo lado. A operação teve lugar no dia 16 de novembro de 1889, tendo sido os ferimentos recebidos na véspera (1 5 de novembro) data da proclamação da República Brasileira. 
Capital Federal, 30 de janeiro de 1890 - Dr. José Pereira Guimarães - Reconheço verdadeira a firma supra - Rio, 30 de janeiro de 1890. Em testemunho da verdade Francisco Pereira Ramos".

Mais adiante encontrei outro retrato do ex-imperador, busto a óleo num quadro dourado e que foi retirado da sala da Câmara Municipal de S. Paulo; vários grupos fotográficos da família imperial; fotografias e litografias com os retratos dos membros do $1^{\circ}$ Governo Provisório da República dos Estados Unidos do Brasil; um belo retrato colorido do último Conselheiro Martim Francisco.

Entre os livros, achei o Primeiro e o Segundo Livro da Infantaria Auxiliar da cidade do Pará, ano 1777 - Uruguai, poema de José Basílio da Gama na Arcádia de Roma Termindo Sipílio, dedicado ao Ilmo. Sr. Francisco Xavier Furtado de Mendonça, Secretário de Estado de S.M.F., etc., etc. Lisboa, na Régia Oficina Tipográfica, ano MDCCLXIX (é cópia manuscrita).

Não pude consultar os demais manuscritos, nem ver as moedas cunhadas e as notas de papel-moeda que estão guardadas em uma vitrina, onde se acham recolhidas verdadeiras joias, relógios, condecorações, caixa do selo da carta do Dr. José Rodrigues Gabriel dos Santos, dada pela Academia de S. Paulo em 1836, um lenço que S. M. - Imperador deixou na estação D. Pedro II, no dia 5 de novembro de 1886 leste lenço é de linho branco, tem num canto um grande $\mathrm{P}$ gótico por baixo da coroa imperial).

São também dignos de menção: a penúltima camisa que vestiu D. Francisco Solano López, o ditador do Paraguai; as vestes sacerdotais que na sua Fazenda das Dores (município de Campinas), usava o Regente Pe. Feijó; a cadeirinha da Sra. Marquesa de Santos; duas espadas do Brigadeiro Rafael Tobias; uma vara medida que foi do Barão de ltapetininga com aferições antiquíssimas, sendo a primeira de 1666; a armadura que usava Martim Afonso de Sousa e a folha da espada do mesmo capitão, trazendo as inscrições seguintes: de um lado Por Meu Rey MDXXX e do outro Por Meu Rey M. A. de S.; uma planta em relevo do terreno de Bragança e Atibaia, trabalho de Carlos Rath; diversas camas, cadeiras, mesas, oratórios e muitos outros objetos mais ou menos antigos ${ }^{32}$.

É necessário apontar que Raffard visitou o Museu Sertório quando este já havia se mudado para um edifício maior, em 1890, onde sua organização fora, consequentemente, alterada. Nessa descrição, já é possível perceber certas diferenças com relação às dos outros visitantes: em meio a peças indígenas e conchas, Raffard menciona a presença de sambaquis, cuja ausência havia sido notada por Koseritz. Tal fato sugere que Sertório estaria ciente das observações do jornalista alemão e, interpretando essa crítica como uma falha na coleção, tratara de conseguir os sambaquis para tornar seu museu mais completo. Além disso, aparece pela primeira vez a menção a uma coleção de livros e manuscritos como parte integrante do museu, assim como de fotografias da família imperial. Ao final, o visitante não deixa de elencar uma série de objetos de cunho histórico que considerou curiosos.

É ainda interessante apontar a existência de identificações nas peças, ao menos nado retrato de D. Pedro II, sendo este, aliás, um objeto bastante recente, contendo a data da proclamação da República, ocorrida um ano antes
32. Cf. Henrique Raffard (1977 [1890], p. 87-89.). 
33. Cf. O Paiz (11 nov. 1884, p. 1).

34. Os fósseis eram considerados um tipo de petrificação na Europa do século XVII, sendo sua origem tema de grandes debates na época. Essas "pedras com figuras" eram as mais procuradas pelos colecionadores. As pedras "comuns" despertavam menos interesse que aquelas que detinham alguma semelhança com vegetais ou animais, pois assinalavam as intersecções entre os diferentes reinos naturais. $\mathrm{O}$ processo de reconhecer os fósseis como restos de organismos vivos foi lento e de difícil aceitação, mesmo que essa ideia tenha sido conhecida dos gregos. O conceito de fóssil era bastante amplo, servindo para definir desde organismos que não mais existiam e que eram encontrados próximo ao mar, até organismos deformados, sendo indícios de espécies já extintas ou desconhecidas, que não se pareciam com nenhum vegetal ou animal conhecido.

35. A batalha de Sedan foi um conflito que ocorreu durante a Guerra Franco-Prussiana (1870-1871), próxima à cidade francesa de Sedan. da visita do cronista. Outro objeto que rememora a mesma data é um quadro com a bala de revólver retirada dos ferimentos do barão de Ladário, tido como a única vítima durante a proclamação. A presença dessas peças mostra como Sertório estava atento à importância da mudança da Monarquia para a República para a história do país e, por isso, procurava reunir objetos que recordassem o episódio.

Museu Sertório também recebeu visitantes ilustres: o imperador D. Pedro II, conhecido pelo gosto pelas ciências, e a Princesa Isabel. Esse evento foi noticiado pela imprensa em 1884 :

Do nosso correspondente, recebemos a seguinte carta:

S. Paulo, 9 de Novembro de $1884-(\ldots)$

Da Sé dirigiram-se Suas Altezas para o museu do coronel Sertório.

É realmente digno de ver-se, e ali o naturalista e o arqueólogo têm muito que apreciar. Nas suas exíguas dimensões o museu Sertório possui verdadeiras preciosidades.

Logo à entrada nota-se um tronco de árvore petrificado, espécime precioso de formação geológica da província. (...)

O sr. Sertório possui uma magnífica coleção numismática. Vi moedas de quase todos os países e o que mais admirei foi uma moeda turca de ouro do século XVI, isto é, do apogeu do domínio otomano no mundo.

Dos fósseis ocupava o primeiro lugar a tíbia e o maxilar inferior de um hipopótamo miocene, descoberto no Rio Grande do Sul.

Notei também uma espada de cavalaria achada no campo de batalha de Sedan e muitos objetos que pertenceram ao ditador López. Entre eles estão alguns papéis, cujo conteúdo não me foi possível apreciar, visto a rapidez da visita.

A zoologia acha-se ali muito bem representada. No centro do salão principal estão um caguardo ou leão sem juba da América e muitos outros animais: preguiças, jacarés, macacos, etc. $(\ldots)^{33}$.

Tal descrição, feita por um correspondente do jornal $\bigcirc$ Paiz, evidencia a presença de fósseis e outras petrificações, que eram objetos importantes nos gabinetes europeus ${ }^{34}$. Os pertences pessoais de Solano López aparecem novamente (já haviam sido mencionados por Koseritz e Raffard), assim como a espada da batalha de Sedan ${ }^{35}$, já citada por Koseritz. A coleção numismática é mais uma vez alvo de elogios. Da coleção zoológica, destaca-se o felídeo americano no centro do salão principal.

Essa mesma visita ainda recebeu uma menção no diário da Princesa Isabel:
Dia 9 de Novembro de 1884

(...) Visita, com Pedro e Luís, ao Museu do Coronel Sertório, que não apareceu, disseram que estava em viagem. Dever ser um grande original. Suas coleções são muito ricas para um particular, infelizmente os animais estão mal conservados, e uma anta, 
entre outros, não permitia que se ficasse perto dela. Gostei muito das coleções de conchas, objetos de índios em penas e moedas ${ }^{36}$.

Em suas recordações, a Princesa Isabel critica o estado de conservação dos animais empalhados, apontando para uma anta mal cheirosa. De forma breve, mostra sua predileção pelas coleções de moedas e de conchas, no que não se diferencia muito das visões de Loefgren, Koseritz e Lomonaco.

$\bigcirc$ retorno do imperador ao local em 1886 também foi destacado na imprensa:

Museu Sertório. Sua Majestade foi recebido pelos srs. coronel Sertório e [J. P. da] Motta Junior ${ }^{37}$. Examinou diversas coleções, prestando especial atenção aos objetos colhidos na província [de São Paulo], mostrando-se satisfeito. (...)

O sr. coronel Sertório ofereceu a Sua Majestade um curioso espécime, uma seriguéa ou gambá (Didelphy cancrivora), mamífero da ordem dos marsupiais, cuja fêmea tem sobre o ventre uma espécie de bolsa em que traz os filhos quando pequenos.

A que foi oferecida a Sua Majestade tinha 10 filhos e foi preparada por um fâmulo do sr. coronel Sertório.

Foi também apresentada a Sua Majestade uma espécie nova, não menos curiosa, do pequeno roedor da família dos cavianos, conhecido entre nós, pelo nome de preiá (caira cobaya).

A nossa preiá não tem cauda, e o espécime supra referido, que foi classificado pelo sr. Alberto Lofgren (sic) sob o nome de Caira Sertorius, trazia uma cauda semelhante a de um rato, o que parece verdadeira anomalia, se é que não se trata realmente de uma nova espécie desconhecida pelos zoólogos ${ }^{38}$.

Essa segunda visita abarca aspectos importantes, como a presença de um naturalista viajante no museu e a preocupação de se tentar produzir algum conhecimento científico a partir das coleções, como demonstra o comentário do jornalista sobre a possibilidade de ter sido classificada uma nova espécie animal que, aliás, deve ter sido nomeada por Loefgren em homenagem ao Coronel Sertório. Outro aspecto curioso é a entrega de um presente a D. Pedro II: uma marsupial fêmea empalhada, contendo dez filhotes dentro da sua bolsa.

A partir dos relatos apresentados, é possível depreender algumas informações sobre o Museu Sertório. A coleção numismática parecia ser um dos destaques, devendo exibir uma rica variedade de moedas, assim como a coleção de conchas (que continha, inclusive, ostras com pérolas). Os objetos que teriam pertencido a Solano López também eram quase sempre mencionados, possivelmente pelo impacto que a Guerra do Paraguai (1864-1870) ainda exercia no país. A mesma importância também era dada a peças que entraram em contato com a família imperial brasileira, como era de se supor, pois eram as figuras-símbolos de poder, grandes personalidades históricas que, até hoje, são alvo de fascínio popular. Grande parte dos animais empalhados não se encontrava em estado de
36. Cf. Diário da Princesa Isabel em visita a São Paulo, apud Carlos Eugênio Marcondes de Moura (1998, p 238).

37. J.P. da Motta Junior era o naturalista viajante do Museu Sertório.

38. Cf. Correio Paulistano (19 nov. 1886, p. 2). O mesmo jornal publicou uma pequena nota em 09 nov. 1886 , p. 1, informando que "(...) O Museu Sertório foi em seguida honrado com a visita de SS. MM. (...)". 
39. Catálogo Antigo (s.d.. Fundo Museu Paulista, Série Inventários do Acervo, Livro 188 ).

40. No Catálogo Antigo, que foi escrito manualmente, existe uma coluna com a indicação "coleção", em que se encontra a letra "S" em praticamente todos os itens listados, com exceção de uma peça desse inventário, que se mostra pertencente à coleção "P"; daí, pode-se supor que "S" signifique "Sertório" e "P", "Pessanha".

41. O índice do Catálogo Antigo ainda contém a Série IV - Numismática, a Série V - Armas, a Série VI - Quadros, a Série VII - Livros, Impressos, Documentos. Contudo, a numeração das páginas, assim como a lista dos itens, termina na Série III - Curiosidades e Artefatos Estrangeiros. Nas páginas seguintes, há uma catalogação de uma coleção numismática, no entanto, ela parece ter sido feita em um período posterior: a escrita cursiva é diferente, assim como a cor da tinta da caneta.

42. Descrições retiradas diretamente do Catálogo Antigo e seguidas de notas com citações que fazem referência à mesma peça ou ao mesmo tipo de peça.

43. Cf. Carl von Koseritz (1980, p. 266-267): "(..) um assento de honra que serviu a D. Pedro I em São Paulo (...) Depois de ter bebido um copo de cerveja fresca (assentado no trono de Pedro I), despedimo-nos do amável colecionador (...)" (grifos meus).

44. Idem (p. 266): “(...) coleção antropológica não é muito valiosa, pois só possui um esqueleto de mulher preparado na Europa e alguns crânios comuns (...)" (grifos meus).

45. Idem (p. 267): “(...) além conservação satisfatório, pelos relatos de Raffard e da Princesa Isabel. Percebe-se, portanto, que a coleção Sertório era bastante heterogênea e formada por uma grande quantidade de objetos, principalmente de ciências naturais e de importância histórica, reunindo elementos que indicam certa continuidade com relação aos gabinetes de curiosidade europeus da era moderna.

Outro documento que parece fazer menção à coleção Sertório é o Catálogo Antigo 39 , encontrado no Fundo Museu Paulista, pois apresenta um inventário do que, provavelmente, seria o acervo inicial do museu, com notações indicando objetos advindos da referida coleção ${ }^{40}$, a procedência das peças, a vitrine onde estavam expostas e observações sobre seu estado de conservação. Conforme o índice na página inicial, no documento são elencados objetos da Seção D - Antropologia e Etnografia (Série I - Antropologia, p. 1; Série II Etnografia, p. 2) e da Seção E - História Pátria, Artes e Artefatos (Série I - História Pátria; Série II - Curiosidades e Artefatos Brasileiros; Série III - Curiosidades e Artefatos Estrangeiros ${ }^{41}$ ). Curiosamente, os itens da coleção de História Natural nele não se encontram.

A partir das descrições do Museu Sertório citadas acima, é possível localizar alguns itens listados no Catálogo Antigo42: "cadeira em que sentou D. Pedro I na sua visita a Jundiaí"43, dois "esqueletos de indivíduos de sexo" não identificado originários da Europa ${ }^{44}$, seis vidros com fetos humanos ${ }^{45}$, dois "flagelários dos jesuítas (disciplina)" 46 , primeiro jornal impresso em papel de ltu 47 , camisa que foi do ditador Francisco Solano López do Paraguai ${ }^{48}$, pedra de dominó que foi do ditador Solano López"49, dois "quadros orográficos da comarca de Bragança pelo Dr. Ratto (sic)"50, "armadura que foi de Martim Afonso de Souza"51, "lenço que foi de D. Pedro II"52, e "vestes sacerdotais de Feijó (3 peças)"53

Um dos empecilhos para confirmar que o Catálogo Antigo se refere à coleção Sertório, contudo, é que não há registro da data em que ele foi feito. No entanto, uma notícia do jornal $\bigcirc$ Estado de S. Paulo forneceu indícios de que o documento pode ter sido elaborado em 1891, quando já existia o Museu do Estado e estava sob a responsabilidade de Loefgren:

Museu

sr. Loefgreen (sic), diretor do museu do estado, organizou o seguinte plano para a classificação de todos os objetos ali existentes:

SEÇÃO A: ZOOLOGIA

SÉRIES

$1^{a}$ Mamíferos.

$2^{a}$ Pássaros. 
$3^{a}$ Répteis e Anfíbios.

$4^{a}$ Peixes.

$5^{a}$ Crustáceos.

$6^{a}$ Insetos.

$7^{a}$ Moluscos e Radiolários.

$8^{\circ}$ Crânios, Chifres, Peles etc.

$9^{a}$ Monstruosidades e Curiosidades.

SEÇÃO B: BOTÂNICA

SÉRIES

$1{ }^{a}$ Plantas avulsas e coleções.

$2^{a}$ Amostras de madeiras e cipós.

$3^{\circ}$ Produtos e Curiosidades vegetais.

SEÇÃO C: GEOLOGIA E MINERALOGIA

SÉRIE

$1^{a}$ Rochas, Minerais e Minérios.

$2^{a}$ Paleontologia (fósseis).

$3^{a}$ Produtos e Curiosidades.

SEÇÃO D: ANTROPOLOGIA E ETNOGRAFIA

SÉRIES

$1{ }^{a}$ Antropologia.

$2^{a}$ Etnografia.

SEÇÃO E: HISTÓRIA E ARTEFATOS

SÉRIES

$1^{a}$ História Pátria.

$2^{a}$ Curiosidades e Artefatos Brasileiros.

$3^{a}$ ditos Estrangeiros.

$4^{a}$ Numismática.

$5^{a}$ Armas (sem serem indígenas as quais pertencem sob Seção D, 2).

$6^{a}$ Quadros.

$7^{a}$ Livros, Impressos e Documentos ${ }^{54}$. de uma quantidade de outras coisas como fetos (...)" (grifos meus).

46. Idem (p. 266): "Ali estão as disciplinas (instrumentos de flagelação) dos velhos conventos de São Paulo (...)" (grifos meus).

47. Ibidem: "(...) coleção de jornais brasileiros (...)"; Correio Paulistano, 27 set. 1882, p. 2: "(...) e até [coleção] de jornais!" (grifos meus).

48. Ibidem: "(...) uma cami$s a$, uma toalha e cartas de Solano López (...)". (grifos meus); Raffard (1977, p. 89): “(...) a penúltima camisa que vestiu $D$. Francisco Solano López, o ditador do Paraguai (...)" (grifos meus).

49. O Paiz (11 nov. 1884, p. 1): “(...) muitos objetos que pertenceram ao ditador López (...)" (grifos meus).

50. Raffard (1977, p. 89): “(...) uma planta em relevo do terreno de Bragança e Atibaia, trabalho de Carlos Rath (...)" (grifos meus).

51. Ibidem: "(...) armadura que usava Martim Afonso de Sousa (...)" (grifos meus).

52. Ibidem: “(...) um lenço que S. M. o Imperador deixou na estação D. Pedro II, no dia 5 de novembro de 1886 (este lenço é de linho branco, tem num canto um grande $\mathrm{P}$ gótico por baixo da coroa imperial) (...)" (grifos meus).

53. Ibidem: “(...) as vestes sacerdotais que na sua Fazenda das Dores (município de Campinas), usava o $R e$ gente Pe. Feijó (...)" (grifos meus).

54 . Cf. O Estado de S. Paulo (10 maio 1891, p. 2).

A classificação proposta por Loefgren, conforme informada pela notícia, mantém a mesma nomenclatura que a existente no Catálogo Antigo, indicando que este documento fora redigido no momento em que o Museu Sertório já havia sido 
55. O Primeiro Relatório do Museu do Estado, redigido em outubro de 1891 por Alexander Hummel, ajudante interino do Museu, fez referência à existência de um catálogo das peças zoológicas, botânicas e geológicas. Contudo, esse documento não se encontra no Fundo Museu Paulista.

56. A hipótese mais provável é a de que o Catálogo não tenha sido completado, uma vez que na página do índice constam as séries de 4 a 7, com uma marcação de página ("pg"), mas sem os números correspondentes.

57. Primeiro Relatório sobre as actuaes condições do Museu do Estado apresentado ao Director do mesmo por Alexander Hummel ajudante interno. (Outubro de 1891. Fundo Museu Paulista, Coleção Alexander Hummel).

58. Idem.

59. Nessa soma, foram contados todos os objetos individualmente, inclusive quando as peças formam conjuntos, como no caso de um relógio e seu suporte de madeira (duas peças, no total), um par de bustos (duas peças, no total), e dois pares de estribos (quatro peças, no total); ainda foram contabilizados dois objetos que constavam ser da coleção Sertório, mas que não se encontram mais nas dependências do Museu Paulista por terem sido furtados em agosto de 2007: uma moeda de 640 réis e uma caixa dede selo feita de prata com as insígnias G.J.R.S.

60. É importante ressaltar que foram encontrados dois tipos de etiquetas: a original e provavelmente contemporânea ao Catálogo Antigo possui detalhes em azul na borda, emoldurando a marcação escrita com uma letra cursiva similar à doado para o Estado, ou seja, mais especificamente em 1891, quando o diretor interino fazia a primeira organização do acervo. Essa notícia também sugere a existência de outro catálogo, contendo a listagem dos objetos pertencentes às coleções zoológica, botânica e geológica ${ }^{55}$, e a própria incompletude do Catálogo Antigo - pois as séries $4^{a}, 5^{a}, 6^{a}$ e $7^{a}$ da Seção E não foram contempladas no documento - ou, ainda, a existência de um terceiro volume contendo as séries que faltavam ${ }^{56}$.

Essa divisão também se repetiu no documento redigido pelo naturalista dinamarquês Alexander Hummel, ajudante interino de Loefgren - o Primeiro Relatório do Museu do Estado, datado de outubro de 1891. A descrição sobre como redigir o catálogo das peças manteve o padrão visto no Catálogo Antigo:

Feito, pois, este inventário preliminar, passamos à primeira seção, compreendendo o Reino Animal, que começamos a estudar por séries, pregando um rótulo com número em cada exemplar, que em seguida era registrado num catálogo pela ordem numérica e o mais possível pela ordem sistemática, com indicação da sua procedência, o lugar (vitrina, caixão, quadro etc.) onde se achava exposto ou guardado, afinal declarando se provinha da coleção Sertório ou da coleção Pessanha ${ }^{57}$ (grifos meus).

Nesse documento, Hummel descreveu o que havia no acervo de História Natural: 90 espécies de mamíferos, com 430 exemplares; cerca de 1.600 pássaros de menos de 400 espécies; 460 exemplares de répteis e anfíbios; 292 números de peixes de quase 100 espécies; uma centena de crustáceos; uma "das mais brilhantes" coleções de insetos; uma "numerosa" coleção de moluscos e radiolários; crânios, peles, ninhos e ovos que "passam de um milhar"; "monstruosidades" que concernem a "animais e aves domésticas de duas cabeças, quatro pernas"; herbário contendo madeiras, cipós, frutos, flores e fibras ${ }^{58}$.

Para além das menções constantes do Catálogo Antigo e do Primeiro Relatório, há peças que ainda se encontram no acervo do Museu Paulista, já categorizadas como coleção Sertório. Neste estudo foram localizados 42 objetos ${ }^{59}$, já identificados pelos próprios funcionários do Museu Paulista, com base na listagem numérica do Catálogo Antigo, na presença de determinado tipo de etiqueta nas peças e na tradição de informações na instituição. Em tais etiquetas ${ }^{60}$, consta uma marcação formada por uma letra seguida por números romanos, o símbolo "N", um número arábico e, às vezes, o nome do objeto por escrito. A numeração presente no Catálogo Antigo e a das etiquetas dos objetos são coincidentes $^{61}$. Com isso, depreendeu-se que esses objetos são remanescentes do Museu Sertório62.

A apresentação das peças a seguir tem o intuito de permitir uma apreensão da coleção do Coronel Sertório em sua materialidade. 
Figuras $^{63}$

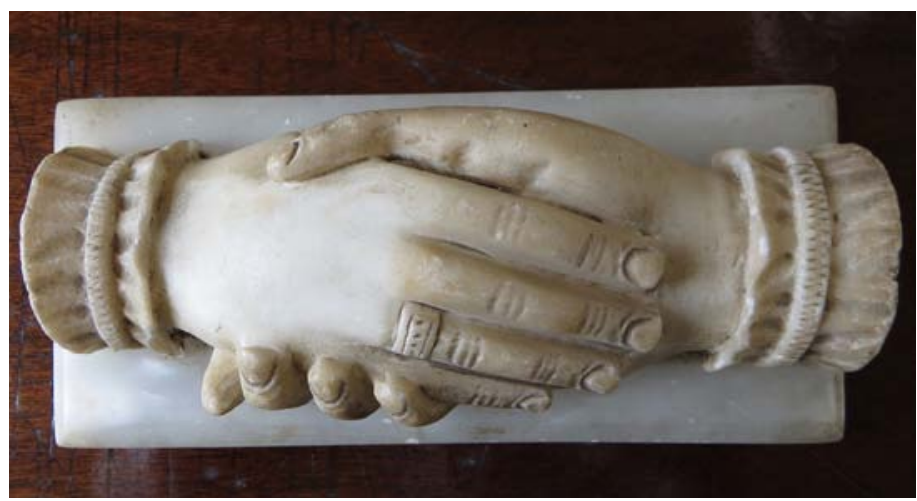

Figura 1: Aperto de mão de alabastro. Não possui etiqueta, mas a ficha catalográfica apresenta referência à marcação do Catálogo Antigo: E.II.III N. 97: "Aperto de mão de alabastro". Catalogado por Heloisa Barbuy. Catálogo eletrônico do Museu Paulista. Acervo do Museu Paulista/USP, São Paulo.
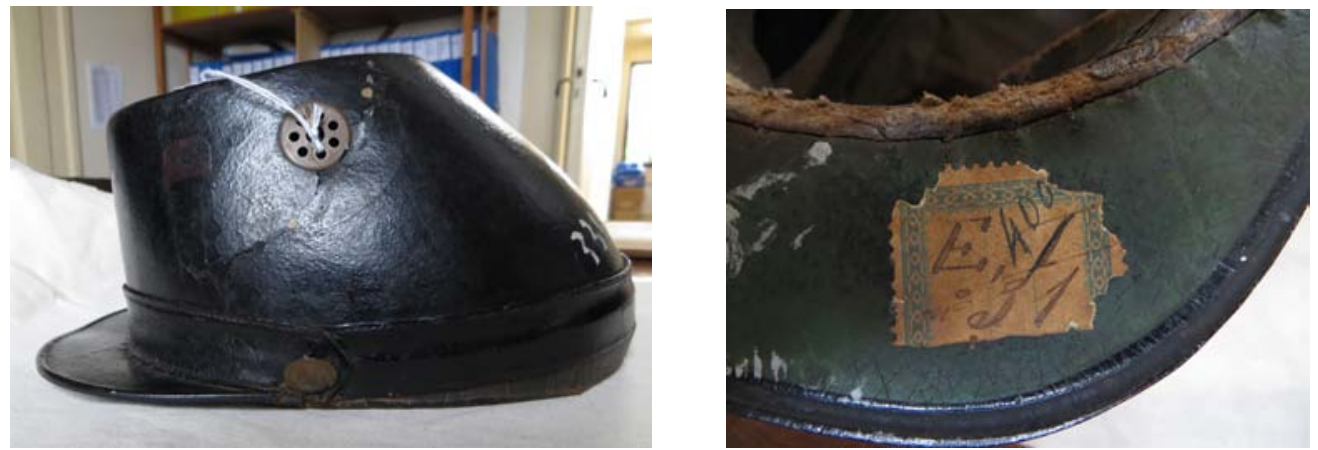

Figuras 2A e 2B: Barretina de couro preto, com insígnia do Corpo Policial Permanente. Possui etiqueta, com marcação referente à do Catálogo Antigo: E.I - N. 31 : "Kepi que foi do Tenente Ramalho". Catalogada por Marisa Basso. Catálogo eletrônico do Museu Paulista. Acervo do Museu Paulista/ USP, São Paulo.

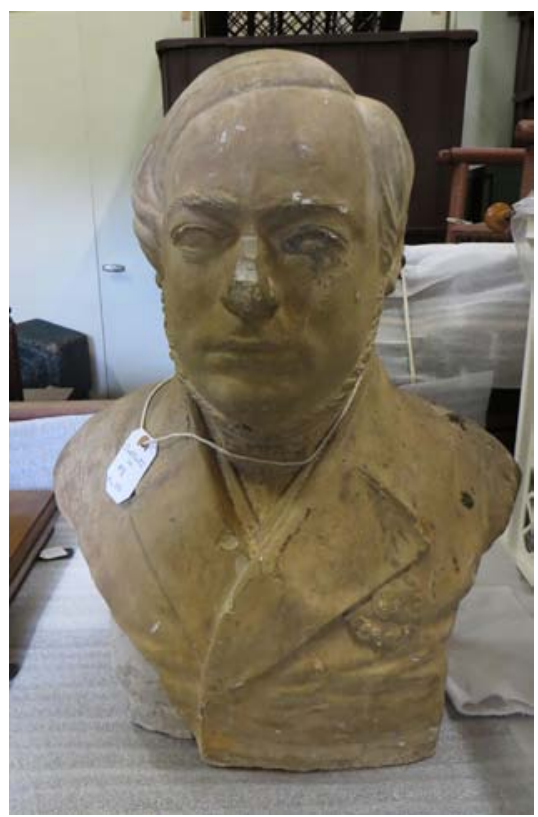

Figura 3: Busto de Gabriel Rodrigues dos Santos. Autoria de Carlos Rath. Não possui etiqueta, mas pode se referir a uma das quatro marcações do Catálogo Antigo: E.I - N. 89, 90, 91 ou 92: "Busto em gesso de Gabriel José Rodrigues dos Santos". Catalogado por Heloisa Barbuy. Catálogo eletrônico do Museu Paulista. Acervo do Museu Paulista/USP, São Paulo. encontrada no próprio Catálogo Antigo; o segundo tipo de etiqueta não possui nenhum detalhe colorido, sendo totalmente branca - é possível que tenha sido usada como substituta da etiqueta com detalhes em azul que estava originalmente colada às peças.

61. Por exemplo, a etiqueta de uma pequena escultura representando uma figura humana chorando especifica "E.II.III No 84 - Estátua de menino que chora". Confrontando essa marcação com a do Catálogo Antigo, percebe-se que são coincidentes: o objeto com a numeração 84 é descrito como "Estatueta, menino que chora", pertencente à "Seção E - Séries II e III - Curiosidades e Artefatos Brasileiros e Estrangeiros". Foram registradas imagens das etiquetas remanescentes em alguns objetos.

62. Em alguns objetos, não consegui encontrar a referida etiqueta, embora houvesse marcação na ficha catalográfica da sua numeração do Catálogo Antigo.

63. Todas as imagens são de minha autoria, com exceção das figuras $12,22,24,36 \mathrm{~A}$, $36 \mathrm{~B}, 38,52,55 \mathrm{~A}, 55 \mathrm{~B}, 62 \mathrm{~A}$ $62 \mathrm{~B}$ e 63 que pertencem ao Acervo do Museu Paulista da Universidade de São Paulo - créditos fotográficos: Hélio Nobre/José Rosael. 

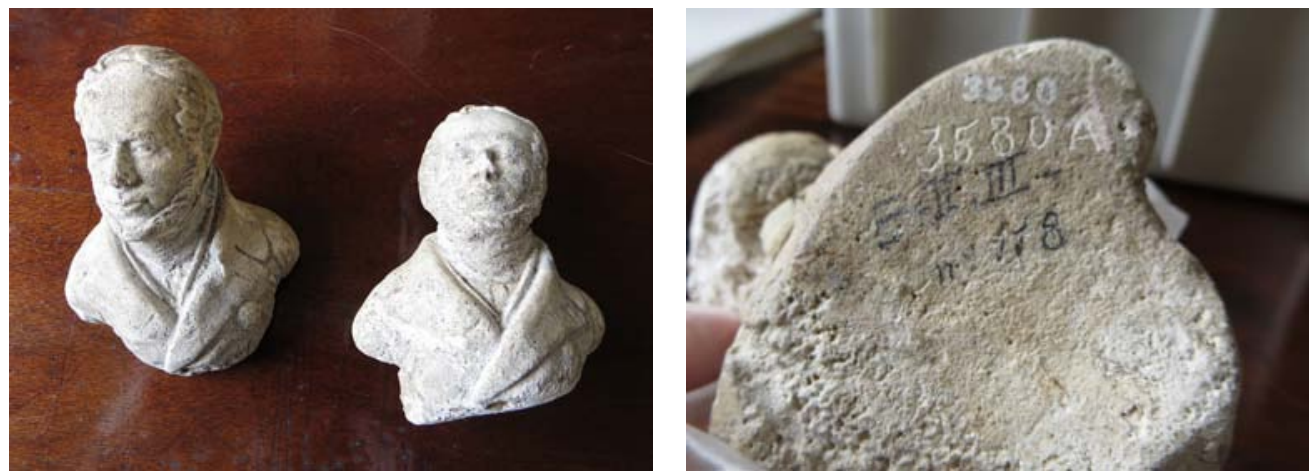

Figuras 4A e 4B: Bustos masculinos (miniaturas). Não possuem etiqueta, mas há marcações a lápis nas bases das duas peças que fazem referência à marcação do Catálogo Antigo: E.II.III - N. 118 : "Bustinhos (dois) de gesso". Catalogados por Heloisa Barbuy. Catálogo eletrônico do Museu Paulista. Acervo do Museu Paulista/USP, São Paulo.

Figura 5: Cadeira de jacarandá, do século XVII. Não possui etiqueta, mas a ficha catalográfica faz referência à marcação do Catálogo Antigo: E.I - N. 8: "Cadeira, que foi do Vigário de Santa Rita, Ytú". Esse objeto pode ser uma das cadeiras referidas na seguinte notícia de O Paiz (27 set. 1886, p. 1): "Sabe-se em S. Paulo por telegrama do Sr. Motta Junior, transmitido de Jundiaí, que aquele senhor acaba de obter para o Museu Sertório, do qual é colecionador viajante, a cama do padre Feijó e três cadeiras do padre Galvão" (grifos meus). Peça descrita por José Wasth Rodrigues, março de 1948. Catalogada por Heloisa Barbuy. Catálogo eletrônico do Museu Paulista. Acervo do Museu Paulista/USP, São Paulo.
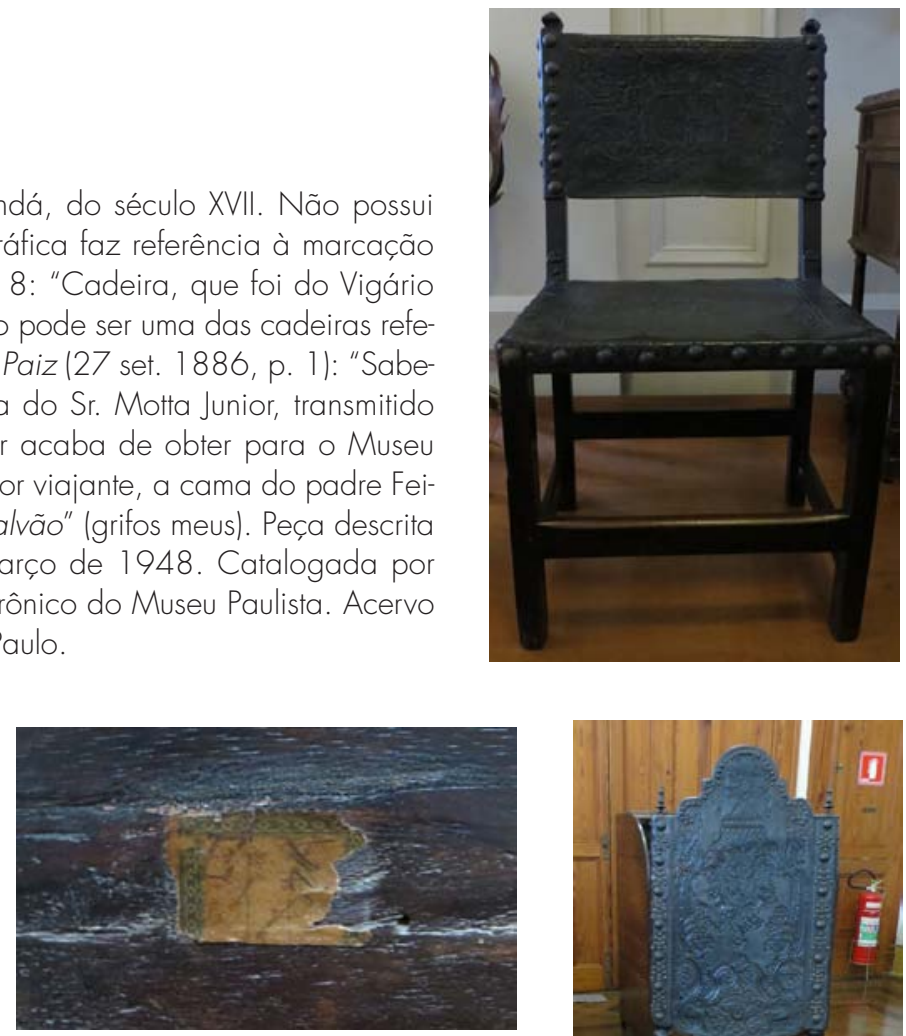

Figuras 6A e 6B: Cadeira de jacarandá da primeira metade do século XVIII. Possui etiqueta, mas a marcação que faz referência à do Catálogo Antigo está rasgada, o que impossibilita sua identificação completa. Peça descrita por José Wasth Rodrigues, março de 1948; Tilde Canti, 1985, p. 1 17. Catalogada por Heloisa Barbuy. Catálogo eletrônico do Museu Paulista. Acervo do Museu Paulista/USP, São Paulo.

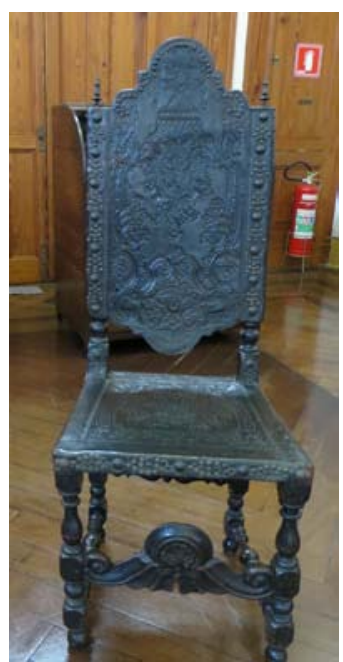



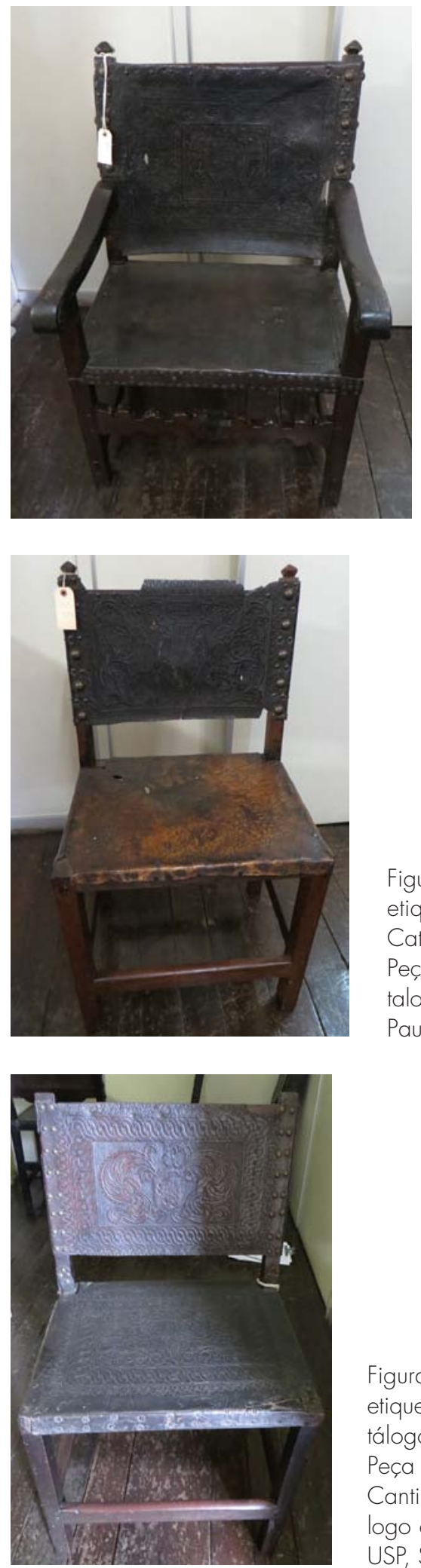

Figura 7: Cadeira de jacarandá datada provavelmente do século XVII. Pertenceu a J. Joaquim Galvão, falecido em ltu, aos 99 anos. Não possui etiqueta, mas a ficha catalográfica apresenta três possíveis referências à marcação do Catálogo Antigo: E.I - N. 10, 11 ou 13: "Cadeira, que foi do Padre José Galvão, Yłú (falecido no anno de 1848, com 99 anos de idade)". Esse objeto pode ser uma das cadeiras referidas na seguinte notícia de O Paiz (27 set. 1886, p. 1): "Sabe-se em S. Paulo por telegrama do Sr. Motta Junior, transmitido de Jundiaí, que aquele senhor acaba de obter para o $\mathrm{Mu}$ seu Sertório, do qual é colecionador viajante, a cama do padre Feijó e três cadeiras do padre Galvão" Igrifos meus). Peça descrita por José Wasth Rodrigues, março de 1948; José de Almeida Santos, 1963. Catalogada por Heloisa Barbuy. Catálogo eletrônico do Museu Paulista. Acervo do Museu Paulista/USP, São Paulo.

Figura 8: Cadeira de jacarandá, do século XVII. Não possui etiqueta com marcação que faz referência à marcação do Catálogo Antigo. Consta que pertenceu à Coleção Sertório. Peça descrita por José Wasth Rodrigues, março de 1948. Catalogada por Heloisa Barbuy. Catálogo eletrônico do Museu Paulista. Acervo do Museu Paulista/USP, São Paulo.

Figura 9: Cadeira de jacarandá, do século XVII. Não possui etiqueta com marcação que faz referência à marcação do Catálogo Antigo. Consta como pertencente à Coleção Sertório. Peça descrita por José Wasth Rodrigues, março de 1948; Tilde Canti, 1985, p. 117. Catalogada por Heloisa Barbuy. Catálogo eletrônico do Museu Paulista. Acervo do Museu Paulista/ USP, São Paulo. 
Figura 10: Cadeira de jacarandá do século XVII. Não possui etiqueta, mas a ficha catalográfica apresenta três possíveis referências à marcação do Catálogo Antigo: E.I - N. 10, 11 ou 13: "Cadeira, que foi do Padre José Galvão, Yłú (falecido no ano de 1848, com 99 anos de idade)". Consta que pertenceu à Coleção Sertório. Esse objeto pode ser uma das cadeiras referidas na seguinte notícia de $O$ Paiz (27 set. 1886, p. 1): "Sabe-se em S. Paulo por telegrama do Sr. Motta Junior, transmitido de Jundiaí, que aquele senhor acaba de obter para o Museu Sertório, do qual é colecionador viajante, a cama do padre Feijó e três cadeiras do padre Galvão" (grifos meus). Peça descrita por José Wasth Rodrigues, março de 1948. Catalogada por Heloisa Barbuy. Catálogo eletrônico do Museu Paulista. Acervo do Museu Paulista/USP, São Paulo.

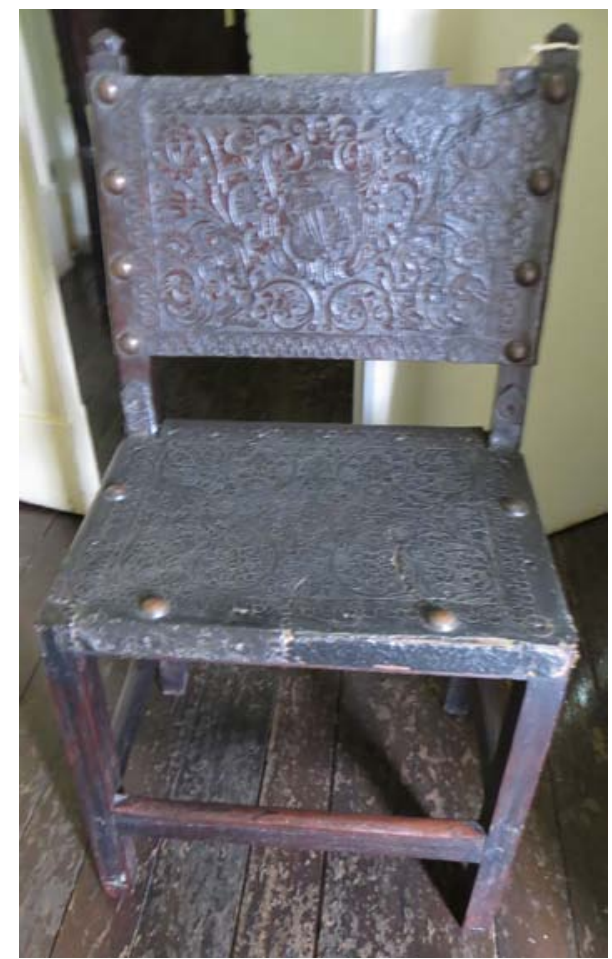

Figura 11: Cadeirão de jacarandá do século XVIII. Consta que pertenceu ao padre Diogo Antonio Feiió (1784-1843). Não possui etiqueta, mas a ficha catalográfica informa a marcação do Catálogo Antigo: E.I - N. 15: "Cadeira, que foi do Padre Diogo Antonio Feijó". Consta que sua procedência é da Coleção Sertório. Esse objeto pode ser uma das cadeiras referidas na seguinte notícia de $O$ Paiz (27 set. 1886: 1): "Sabe-se em S. Paulo por telegrama do Sr. Motta Junior, transmitido de Jundiaí, que aquele senhor acaba de obter para o Museu Sertório, do qual é colecionador viajante, a cama do padre Feijó e três cadeiras do padre Galvão" (grifos meus). Peça descrita por José Wasth Rodrigues, março de 1948, José de Almeida Santos, 1963; Tilde Canti, 1985, p. 124. Catalogada por Heloisa Barbuy. Catálogo eletrônico do Museu Paulista. Acervo do Museu Paulista/USP, São Paulo.

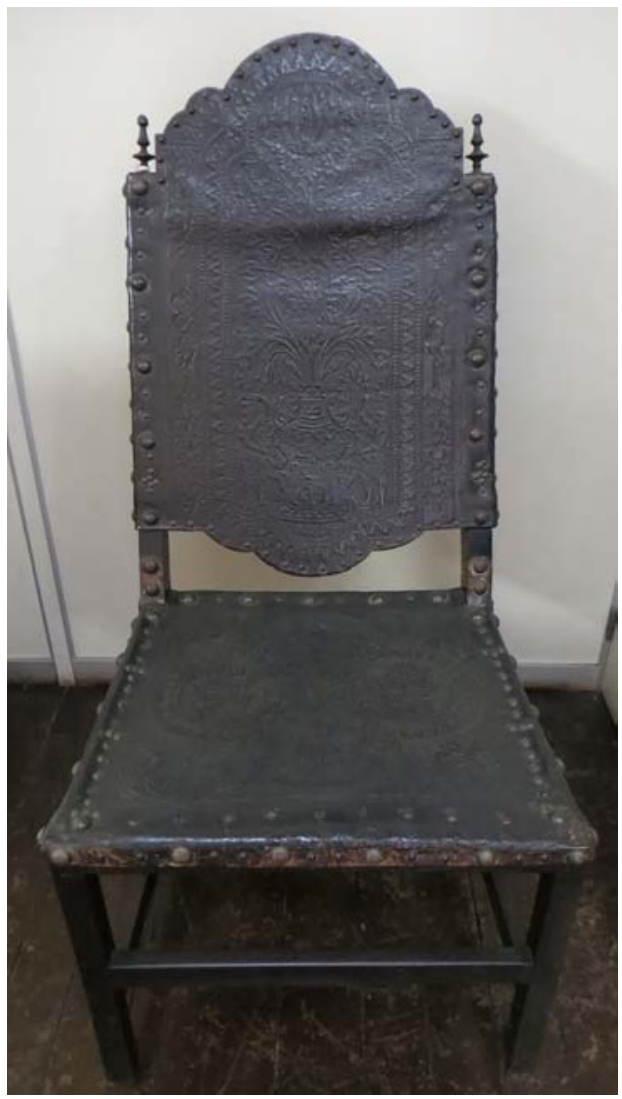




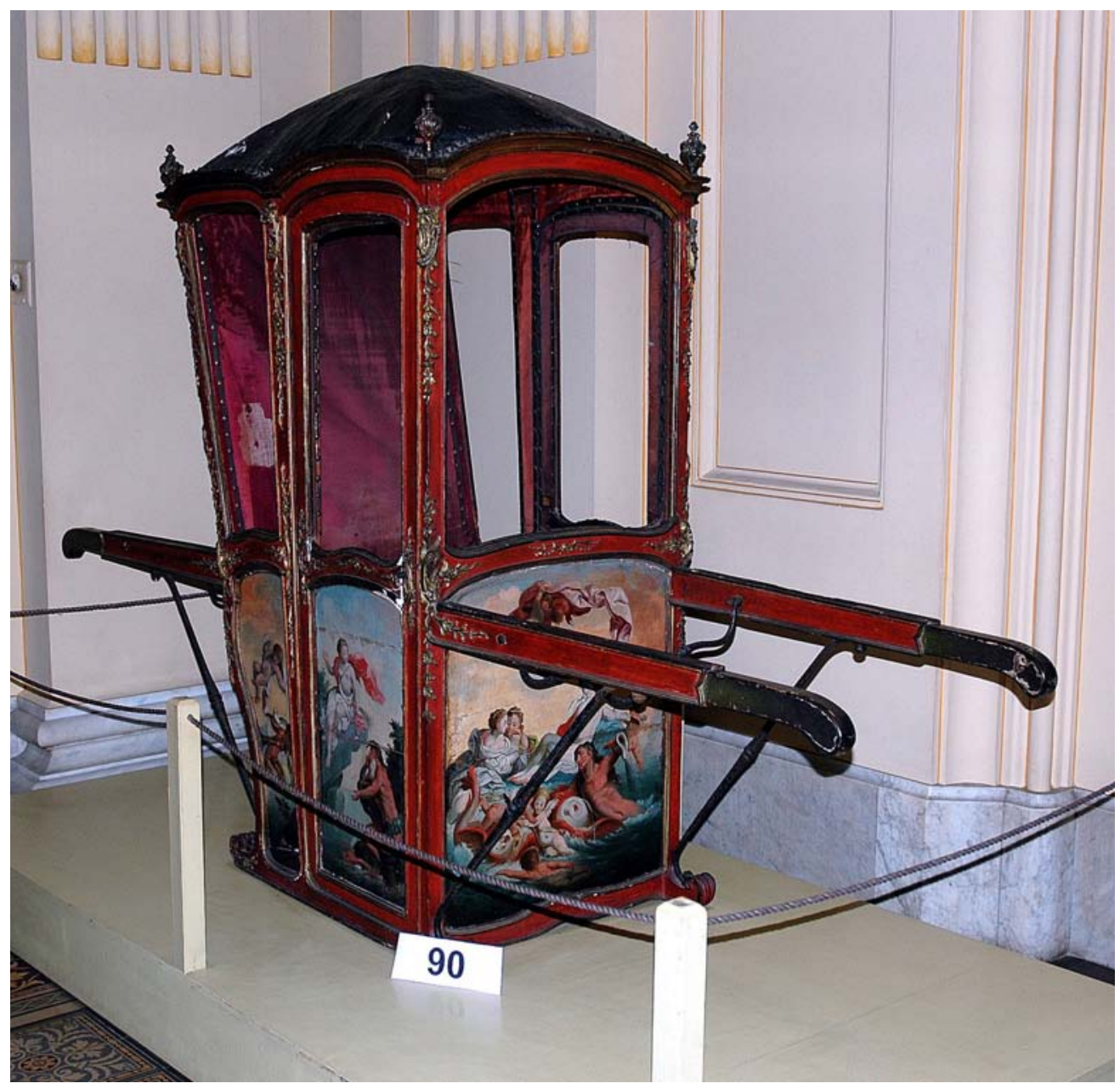

Figura 12: Cadeirinha de arruar em estilo D. Maria I, com entalhes dourados e pinturas. Raffard (1977, p. 89, 1.ed. 1890) indicou a presença dessa peça no Museu Sertório: "São também dignos de menção: (...) a cadeirinha da Sra. Marquesa de Santos; (...)". . Não possui etiqueta, mas a ficha catalográfica contém marcação que faz referência à do Catálogo Antigo: E.I - N. 19: "Cadeirinha da Exma. Dra. Da. Marquesa de Santos oferecida pela Sra. Dna. Cássia.... em 1886". Segundo detalhado relato do cronista Antonio Egídio Martins, entre 1905 e 1910, a peça teria pertencido originalmente a Frei Manuel da Ressurreição, e não à Marquesa de Santos como se acreditava. Mais tarde, essa peça passou a ser do pai de Antonio Egídio, o comerciante Lourenço Domingues Martins, em 1854; depois teria passado a Rita de Cássia da Silva Bueno, que a ofereceu ao Museu Sertório. Segundo consta em notícia do Diário Popular de 08 de novembro de 1886: "Cadeirinhaa Sra. D. Rita de Cássia da Silva Bueno, inteligente filha do Sr. Joaquim Elias da Silva Bueno, fez um rico presente ao Museu Sertório, consistindo numa cadeirinha (que no século passado servia para conduzir gente) dourada e pintada de vermelho, externamente, e tendo na caixa delicados painéis a óleo, representando alegorias mitológicas. / Internamente a cadeirinha é toda forrada de veludo carmesim e as suas vidraças adornadas com ramagens a ouro. É para se lamentar não se saber a quem pertenceu essa preciosidade, que demonstra o bom gosto e a opulência que sustentava o seu primitivo dono, naqueles belos tempos idos". Cf.Martins (1973, p. 289). Descrita por José Wasth Rodrigues, conforme transcrição do Catálogo eletrônico do Museu Paulista. Catalogada por Heloisa Barbuy. Acervo do Museu Paulista/USP, São Paulo. 
Figura 13: Camisa, do século XIX. Não possui etiqueta, mas consta na ficha catalográfica referência à marcação no Catálogo Antigo: E.I - N. 51: "Camisa que foi do ditador Francisco Solano López do Paraguai". A ficha catalográfica apresenta a seguinte observação sobre o objeto: "Consta nos antigos fichários como doação do Comendador Dr. Duarte Azevedo; Koseritz menciona uma camisa de Solano López no Museu Sertório. Duarte de Azevedo pode ser o último proprietário antes de Sertório, já que no caso da cadeirinha de arruar acontece esta situação". Koseritz (1980, p. 266, 1.ed. 1883) relatou que o Museu Sertório possuía uma camisa, uma toalha e cartas de Solano López; Raffard (1977, p. 89, 1.ed. 1890) também fez menção à "penúltima camisa que vestiu D. Francisco Solano López, o ditador do Paraguai". Catalogada por Heloisa Barbuy. Acervo do Museu Paulista/USP, São Paulo.
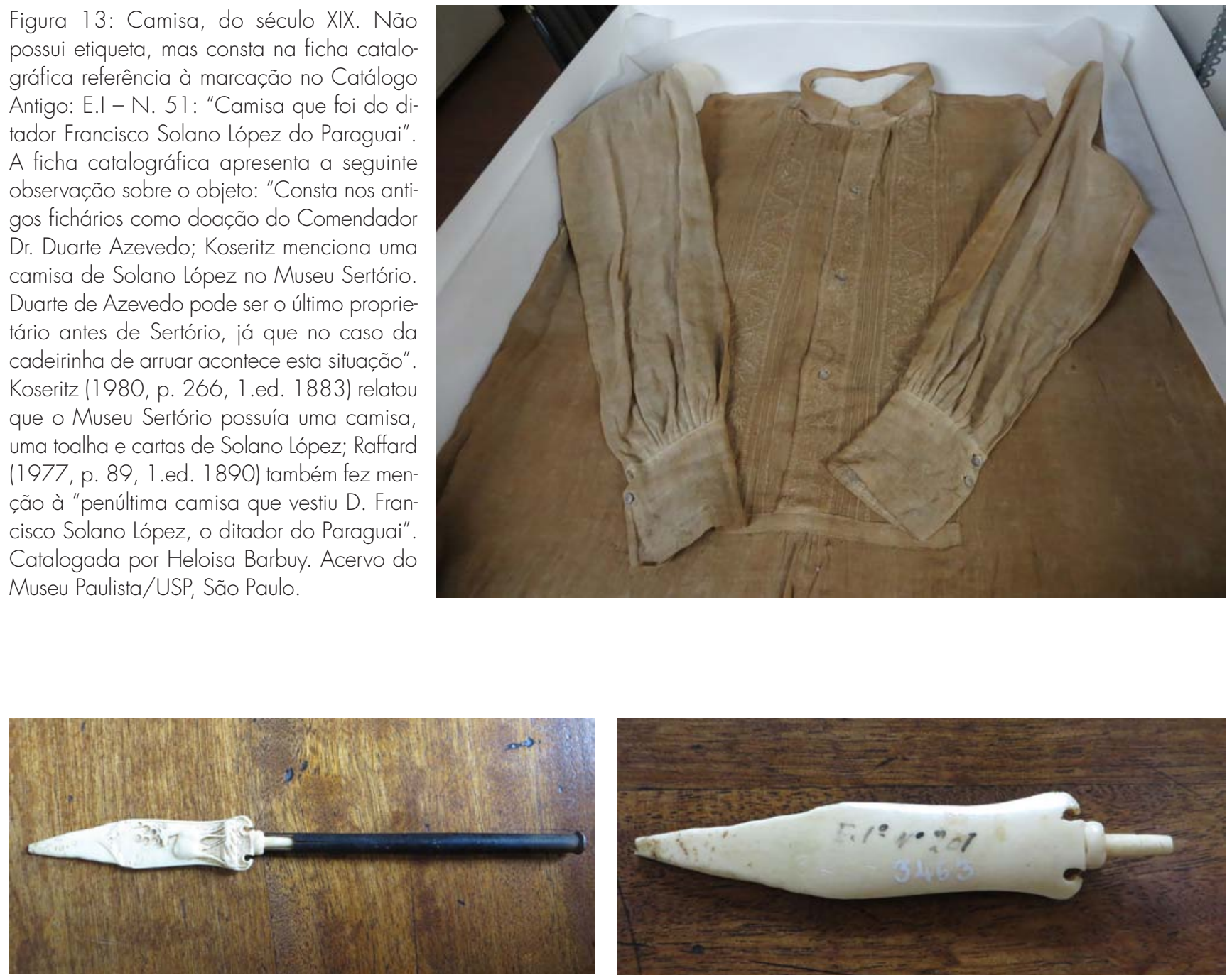

Figuras 14A e 14B: Caneta com ponta de marfim, cabo de madeira; não tem carga ou pena. Não possui etiqueta, mas contém uma marcação em caneta preta que faz referência à marcação no Catálogo Antigo: E.I - N. 20 1: "Caneta (pedaço) de marfim com veado em relevo". Catalogada por Heloisa Barbuy. Catálogo eletrônico do Museu Paulista. Acervo do Museu Paulista/USP, São Paulo.
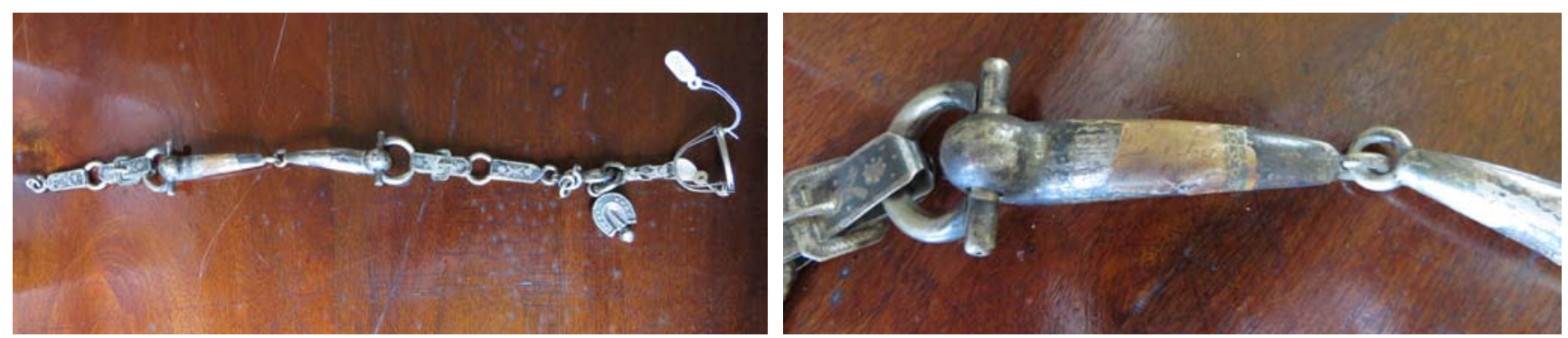

Figuras 15A e 15B: Correia (miniatura) com partes imitando faixas de couro com fivelas, uma ferradura e um estribo. Possui etiqueta com marcação de difícil visibilidade, mas consta no Catálogo Antigo: E.I - N. 146: "Corrente de prata". Catalogada por Heloisa Barbuy. Catálogo eletrônico do Museu Paulista. Acervo do Museu Paulista/USP, São Paulo. 

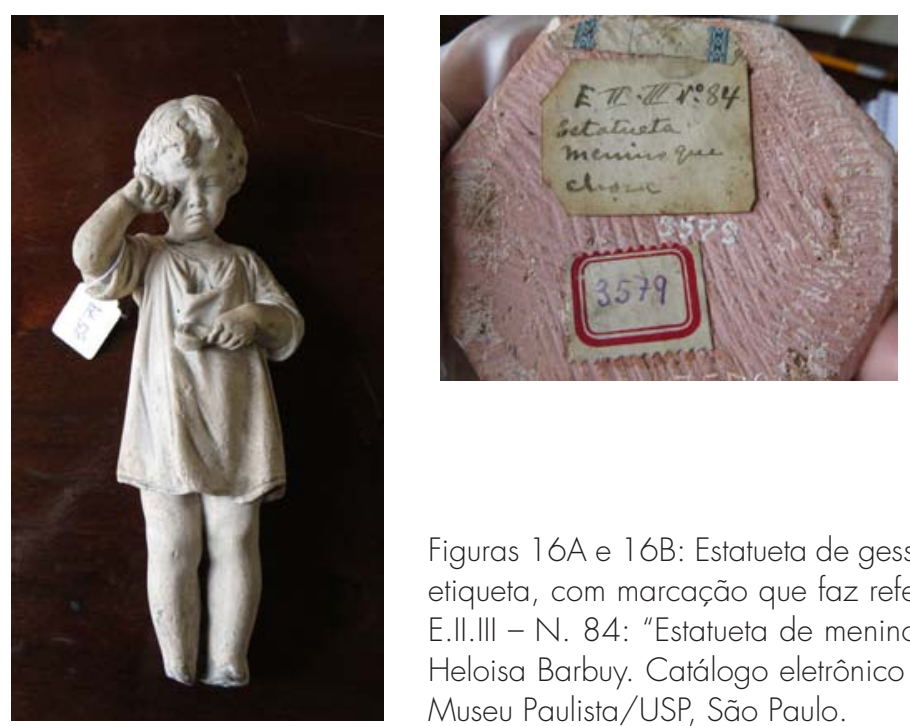

Figuras 16A e 16B: Estatueta de gesso de menino que chora. Possui etiqueta, com marcação que faz referência à do Catálogo Antigo: E.II.III - N. 84: "Estatueta de menino que chora". Catalogada por Heloisa Barbuy. Catálogo eletrônico do Museu Paulista. Acervo do Museu Paulista/USP, São Paulo.
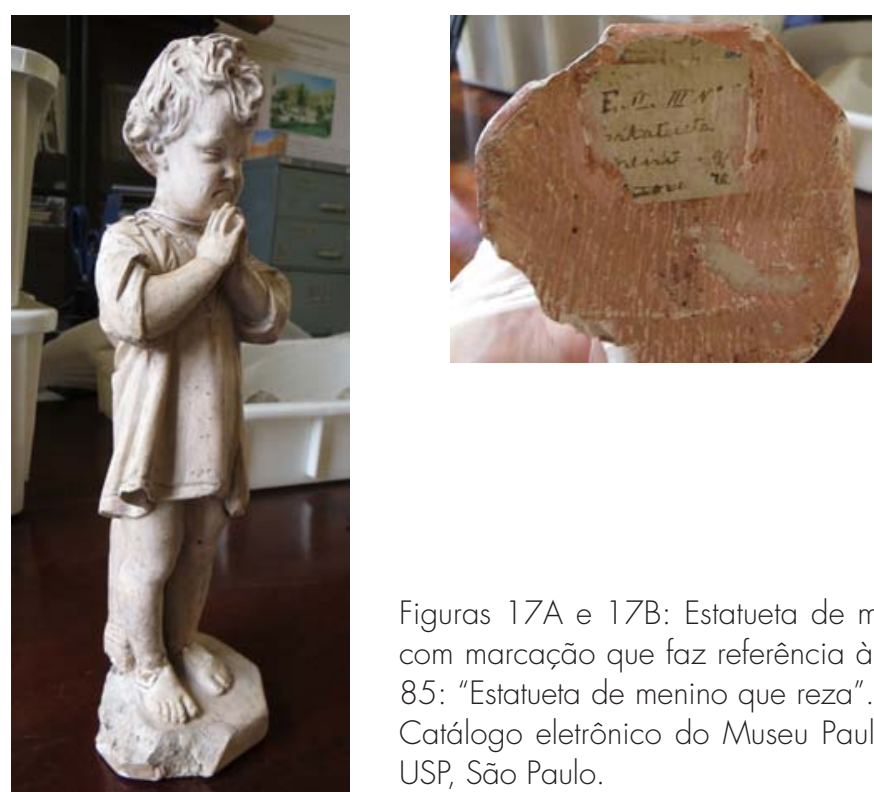

Figuras 17A e 17B: Estatueta de menino que reza. Possui etiqueta, com marcação que faz referência à do Catálogo Antigo: E. II. III - N. 85: "Estatueta de menino que reza". Catalogada por Heloisa Barbuy. Catálogo eletrônico do Museu Paulista. Acervo do Museu Paulista/ USP, São Paulo.

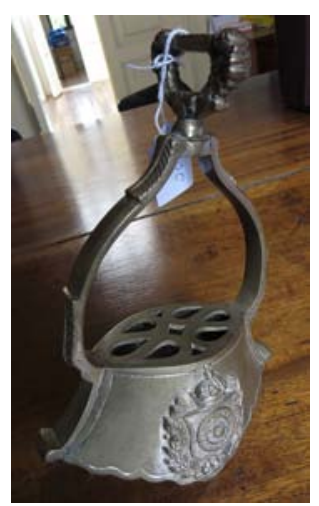

Figura 18: Estribo de prata com armas imperiais. Não possui etiqueta, mas pode fazer referência à marcação do Catálogo Antigo: E.I - N. 195: "Estribo de prata com armas imperiais". Catalogado por Heloisa Barbuy. Catálogo eletrônico do Museu Paulista. Acervo do Museu Paulista/USP, São Paulo. 
Figuras 19A, 19B e 19C: Par de estribos de São Luiz do Paraitinga (SP). Possui etiqueta, com marcação que faz referência à do Catálogo Antigo: E.I - N. 24: "Par de caçambas que foram de Vigário J.J. Roiz, Jundiaí". Catalogado por Heloisa Barbuy. Catálogo eletrônico do Museu Paulista. Acervo do Museu Paulista.
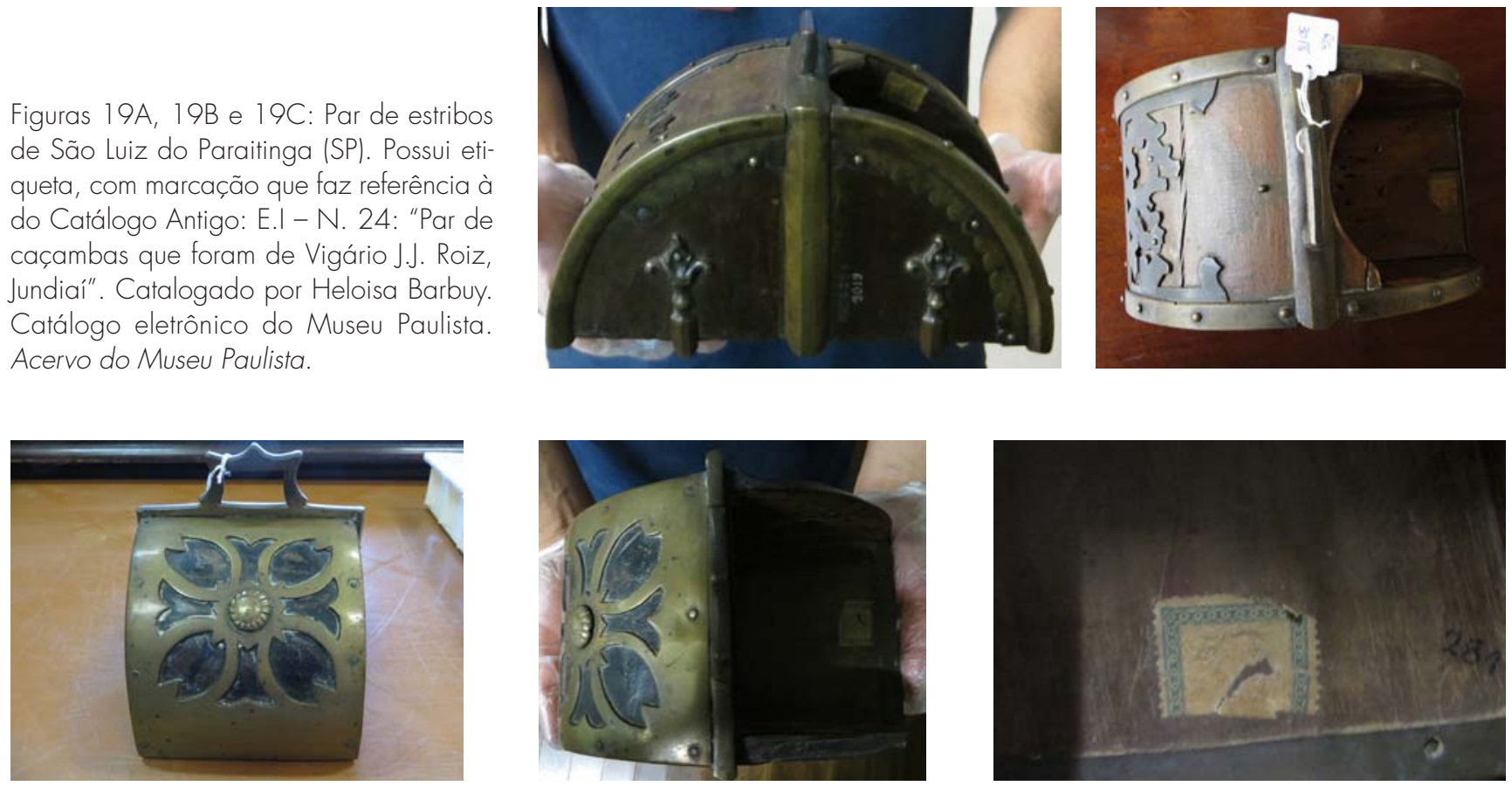

Figuras 20A, 20B e 20C: Par de estribos de São Luiz do Paraitinga (SP). Possui etiqueta, no entanto, a referência à marcação do Catálogo Antigo está ilegível, contudo poderia ser: E.I - N. 23 ou 25: "Par de caçambas que foram de Vigário J.J. Roiz, Jundiaí". Na ficha catalográfica consta que o doador foi o "Coronel J.J. Raposo". Algumas das peças pertencentes à coleção Sertório apresentam nos registros do Museu Paulista nomes de doadores distintos de Francisco Paula Maryink, como é o caso desses estribos. Isso não significa que não teriam feito parte do Museu Sertório, uma vez que poderiam ter passado ao Museu Paulista como doação de quem cedeu originalmente o objeto para o Coronel Sertório. Nesse caso, J.J. Raposo teria sido o doador do par de estribos ao Museu Sertório, sendo que esse registro teria passado ao Museu Paulista; além disso, Raposo era cunhado de Joaquim Sertório, pois era casado com Maria do Carmo Sertório Raposo, irmã do coronel. Esse mesmo raciocínio serve para as outras peças que constam nessa listagem e que têm registrado J.J. Raposo como seu doador (caso das figuras 41, 42, 43, 45, 46 e 47). Catalogado por Heloisa Barbuy. Catálogo eletrônico do Museu Paulista. Acervo do Museu Paulista/USP, São Paulo.
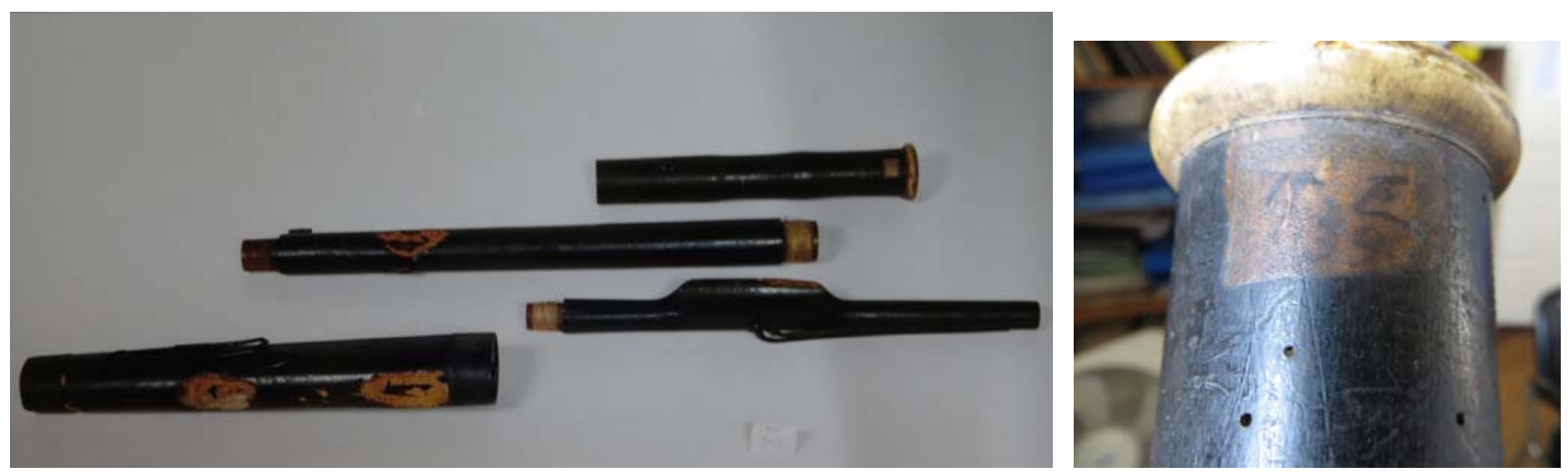

Figuras 21A e 21B: Fagote, instrumento de sopro, feito com quatro peças encaixáveis de madeira em cor escura. Possui etiqueta com marcação que faz referência à do Catálogo Antigo: E.I - N. 39: "Instrumento musical antigo (fagote)". Catálogo eletrônico do Museu Paulista. Acervo do Museu Paulista/USP, São Paulo. 


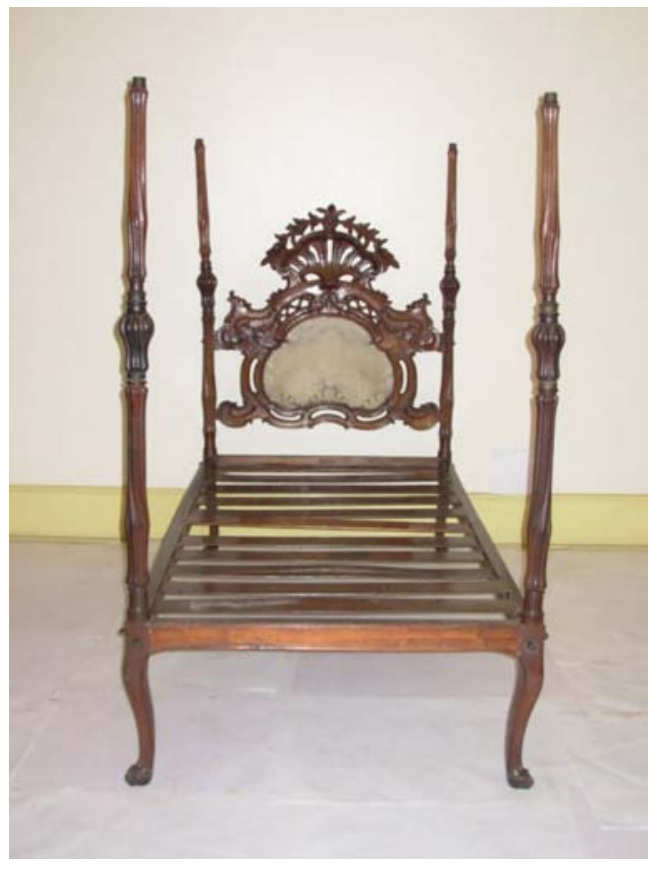

Figura 22: Cama de solteiro, no estilo D. Maria I. Leito que pertenceu ao Padre Diogo Antonio Feijó e onde faleceu o estadista. Não possui etiqueta, mas pode se referir à marcação do Catálogo Antigo: E.I - N. 26: "Cama antiga que foi do Padre Diego Antonio Feiió". Esse objeto pode ser a cama referida na seguinte notícia de $O$ Paiz 127 set. 1886, p. 1): "Sabe-se em S. Paulo por telegrama do Sr. Motta Junior, transmitido de Jundiaí, que aquele senhor acaba de obter para o Museu Sertório, do qual é colecionador viajante, a cama do padre Feijó e três cadeiras do padre Galvão" (grifos meus). Catalogada por Heloisa Barbuy. Catálogo eletrônico do Museu Paulista. Acervo do Museu Paulista/USP, São Paulo.
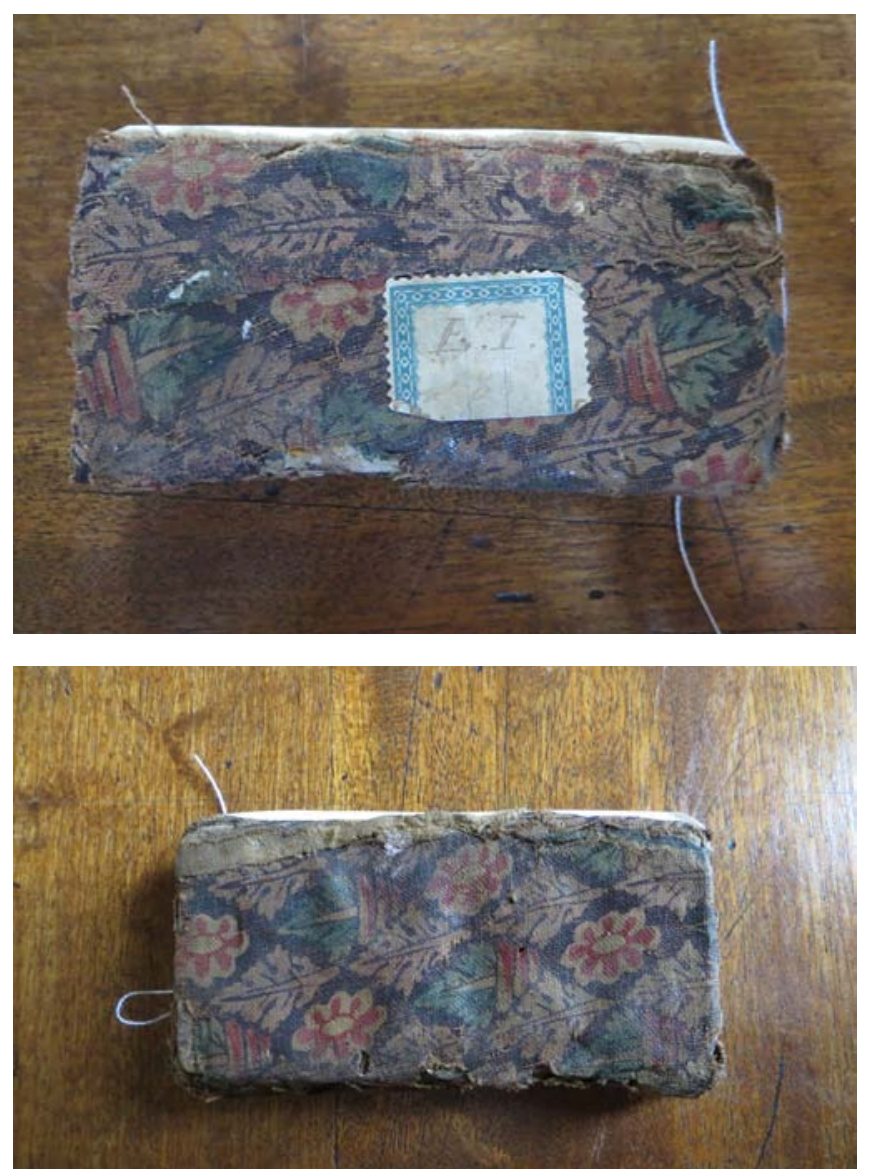

Figuras 23A e 23B: Livro de rezas de 234 páginas; faltam as 25 primeiras, não contando, assim, tífulo ou autor; com ilustrações. Pertenceu a Pascoal Barbosa. Possui etiqueta com marcação que faz referência à do Catálogo Antigo: E.I - N. 86: "Livro de rezas que foi de Pascoal Barbosa". Catalogado por Heloisa Barbuy. Catálogo eletrônico do Museu Paulista. Acervo do Museu Paulista/USP, São Paulo. 
Figura 24: Marco de origem seiscentista que durante mais de dois séculos esteve situado no centro de São Paulo, no largo da Sé, como centro de demarcação do rocio da Vila e Cidade de São Paulo. Consta na ficha que "a palavra 'rocio' deriva do verbo 'roçar' e era o nome dado ao terreno roçado e usufruído por uma coletividade. Tudo isso indica que essa denominação tenha surgido para designar as áreas destinadas à exploração agrícola à volta de certas igrejas, constituindo, assim, o 'patrimônio' de seus santos oragos. / Essa expressão estendeu-se ao território sob a jurisdição das câmaras antigas de vilas e seria aplicável hoje ao que chamamos de 'perímetro urbano' dos municípios. Além dos limites do rocio, havia a zona rural. A concessão de áreas situadas dentro do perímetro urbanizado era dada pela Câmara, que poderia cobrar aforamento e os terrenos externos seriam devolutos e cedidos somente pelo donatário da Capitania, Martim Afonso, e seus descendentes, no caso paulistano". Porta (2004, p. 155). Não contém etiqueta, mas consta que pertenceu à coleção Sertório. Catalogado por Heloisa Barbuy. Acervo do Museu Paulista/USP, São Paulo.

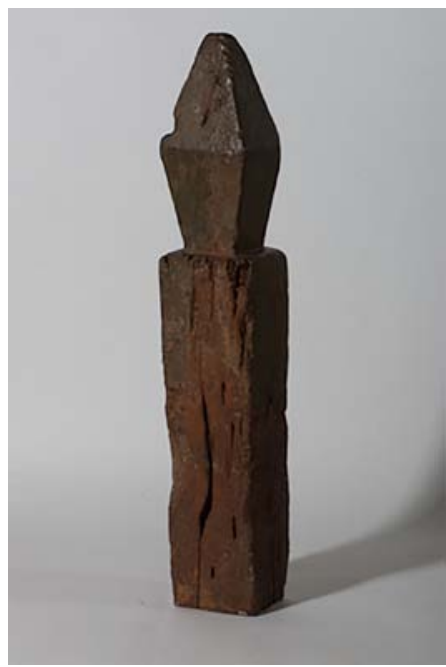

Figuras 25A e 25B: Par de caçambas de madeira de São Luiz do Paraitinga. Em um dos estribos, consta na etiqueta rasgada: "... do capitão-m.../ ... S. Luis do Pa.../...(o)fferecidas p.../ ...Guimarães..."; essa marcação faz referência à do Catálogo Antigo: E.I - N. 22: "Par de caçambas que foram dum guarda-mór". Catalogado por Heloisa Barbuy. Catálogo eletrônico do Museu. Acervo do Museu Paulista/USP, São Paulo.
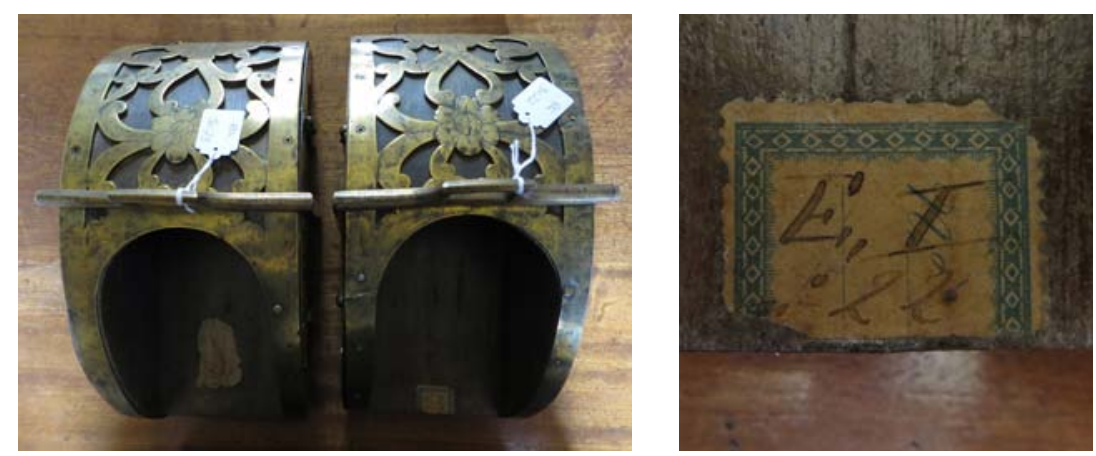

Figuras 26A e 26B: Pedra de dominó. Consta que pertenceu a Solano López, presidente paraguaio quando da Guerra do Paraguai. Consta um pequeno pedaço da etiqueta na peça. A ficha catalográfica faz referência à marcação do Catálogo Antigo: E.I N. 180: "Pedra de dominó que foi do Ditador Solano López". A ficha catalográfica ainda contém essa observação: "Entregue pelo Dr. Taunay em 30/1 1/1945". Catalogada por Heloisa Barbuy. Catálogo eletrônico do Museu Paulista. Acervo do Museu Paulista.
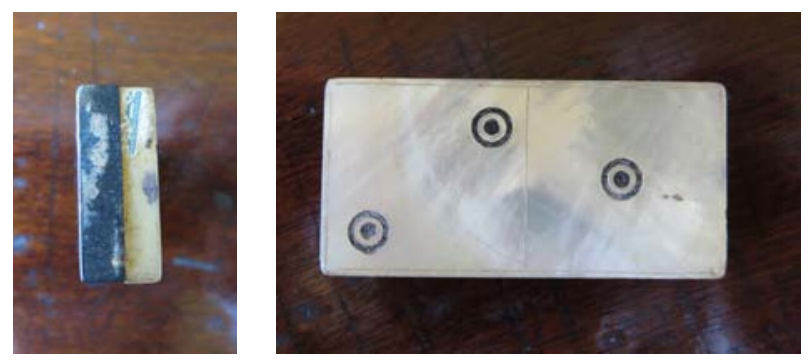

Figura 27: Pires de porcelana branca. Não possui etiqueta, mas a ficha catalográfica faz referência à marcação do Catálogo Antigo: E.II.III - N. 55: "Pires (2) desemparelhados". Catalogado por Heloisa Barbuy. Catálogo eletrônico do Museu Paulista. Acervo do Museu Paulista/USP, São Paulo.

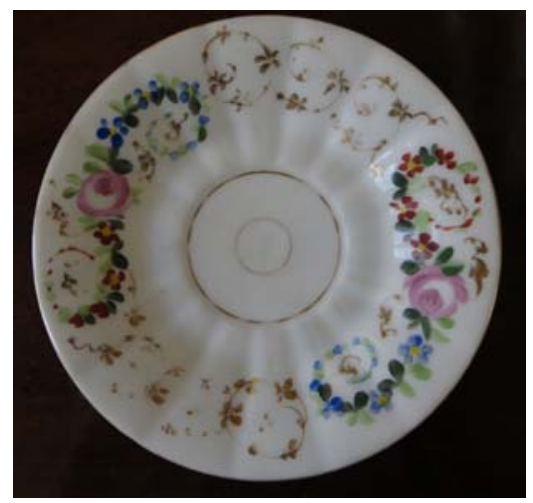




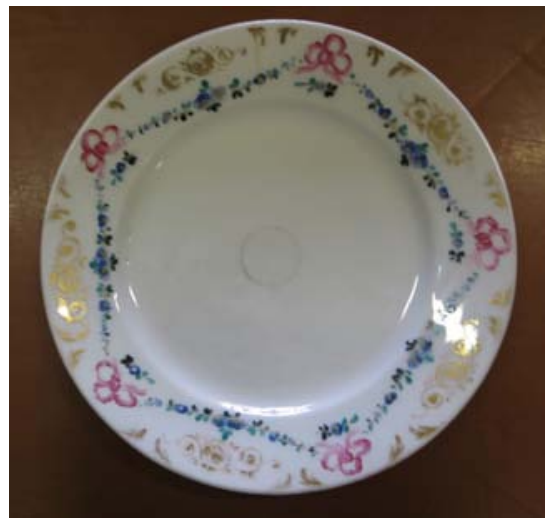

Figura 28: Prato pequeno sem marca. Não possui etiqueta, mas a ficha catalográfica faz referência à marcação do Catálogo Antigo: E.II.III - N. 41 : "Prato japonês". Catalogado por Suzana Fernandes. Catálogo eletrônico do Museu Paulista. Acervo do Museu Paulista/USP, São Paulo.

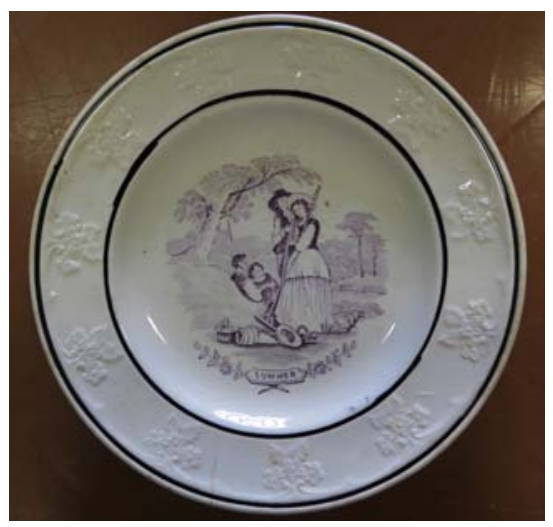

Figura 29: Prato pequeno sem marca. Não possui etiqueta, mas a ficha catalográfica faz referência à marcação do Catálogo Antigo: E.II.III - N. 39: "Prato travessa". Catalogado por Suzana Fernandes. Catálogo eletrônico do Museu Paulista. Acervo do Museu Paulista.
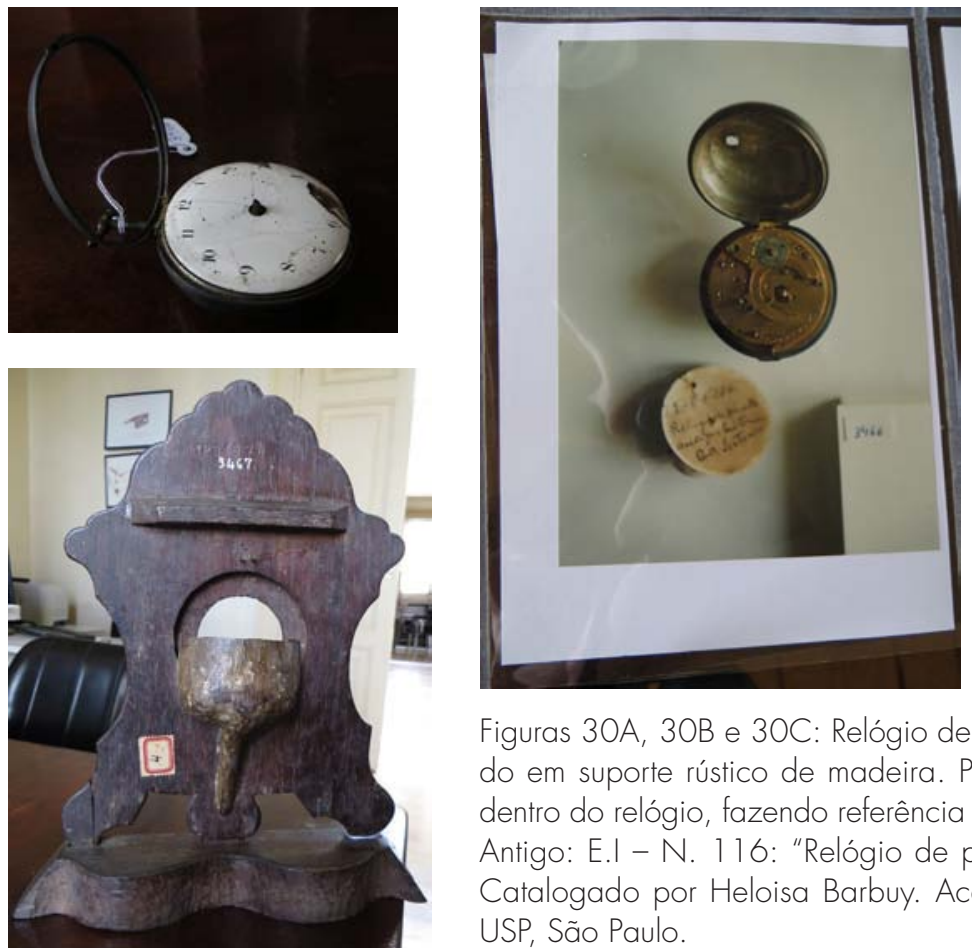

Figuras 30A, 30B e 30C: Relógio de prata, tipo de bolso, usado em suporte rústico de madeira. Possuía etiqueta - situada dentro do relógio, fazendo referência à marcação do Catálogo Antigo: E.I - N. 1 16: "Relógio de prata, antigo e histórico". Catalogado por Heloisa Barbuy. Acervo do Museu Paulista/ USP, São Paulo. 

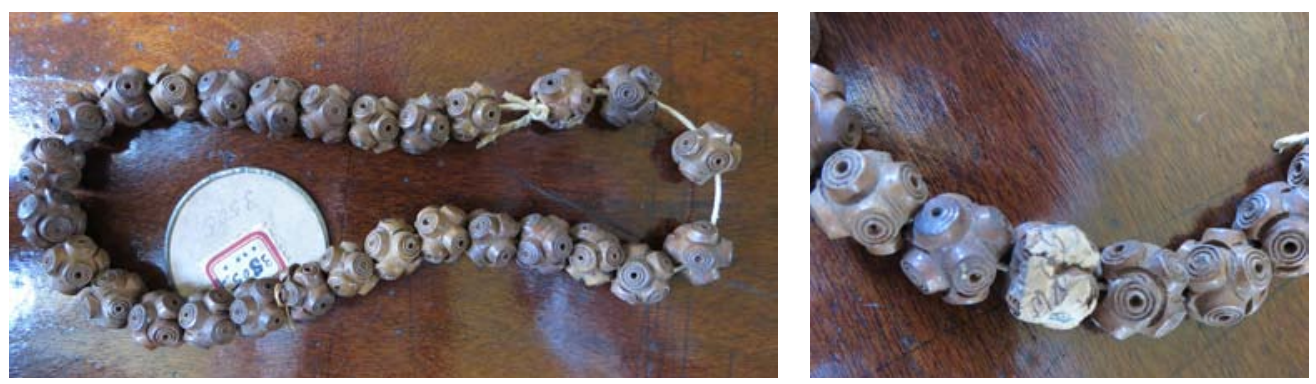

Figuras 31 A e 3 1B: Rosário da região de Lourdes (França), com barbante com 28 contas. Possui etiqueta rasgada; a ficha catalográfica faz referência à marcação do Catálogo Antigo: E.I - N. 145: "Rosário". É possível que esse objeto seja o referido nesta notícia do Correio Paulistano (05 dez. 1891, p. 1): "O sr. Aureliano Coutinho, de última hora, arrependeu-se de haver tomado a resolução de entrar para um convento. $\bigcirc$ hábito que S.S. já havia comprado teve outro destino. O rosário, esse foi destinado ao Museu Sertório para figurar ali como relíquia de retratação por S.S., apresentada ao Congresso Paulista" (grifos meus). É importante comentar que esse objeto deve ter ido parar na coleção no momento em que o Museu Sertório já havia sido doado para o governo estadual devido à data da notícia. Catalogado por Heloisa Barbuy. Catálogo eletrônico do Museu Paulista. Acervo do Museu Paulista/USP, São Paulo.

Figura 32: Serpentão feito de cobre, couro e metal. Instrumento musical de sopro lespécie de trombone antigo). Não possui etiqueta; consta na ficha catalográfica uma possível referência a essa peça no Catálogo Antigo: E.I - N. 38: "Instrumento musical antigo". Esse objeto pode ser o que aparece nesta notícia do Correio Paulistano (27 set. 1882, p. 2): "Naquelas coleções [de Sertório] há de tudo, raridades, curiosidades e monstruosidades de toda sorte: um serpentão antiquíssimo, instrumento de música, feito de sola, de feitio singularíssimo" (grifos meus). Catálogo eletrônico do Museu Paulista. Acervo do Museu Paulista/USP, São Paulo.

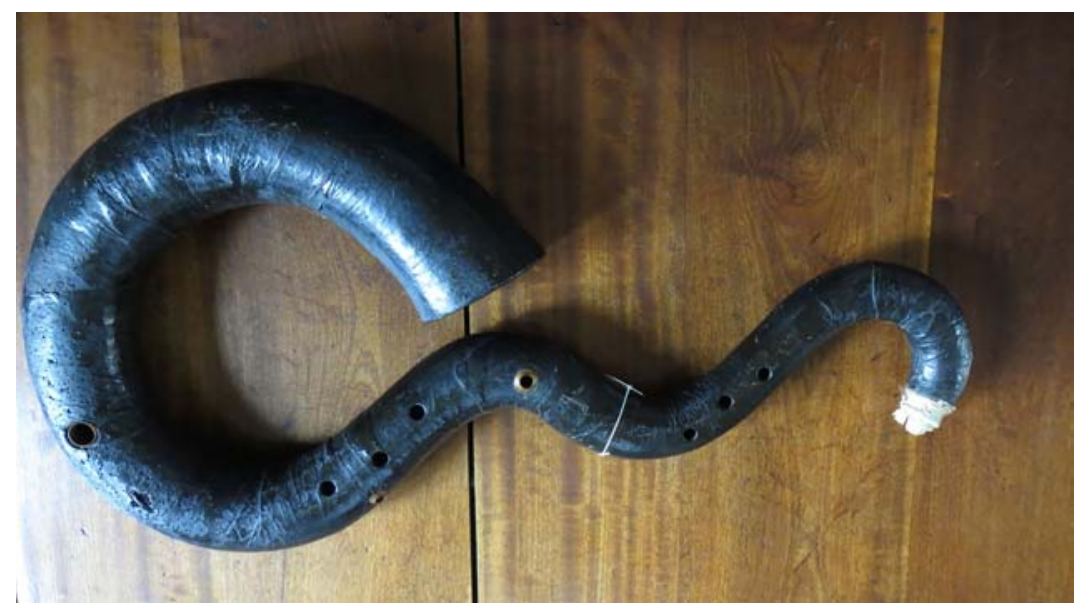

Figuras 33A e 33B: Tampa de sopeira de porcelana branca. Possuía etiqueta, localizada na parte inferior da tampa, fazendo referência à marcação do Catálogo Antigo: E.II.III - N. 25: "Sopeira com tampa Isó existe a tampa)". Catalogada por Suzana Fernandes. Catálogo eletrônico do Museu Paulista. Acervo do Museu Paulista/ USP, São Paulo.
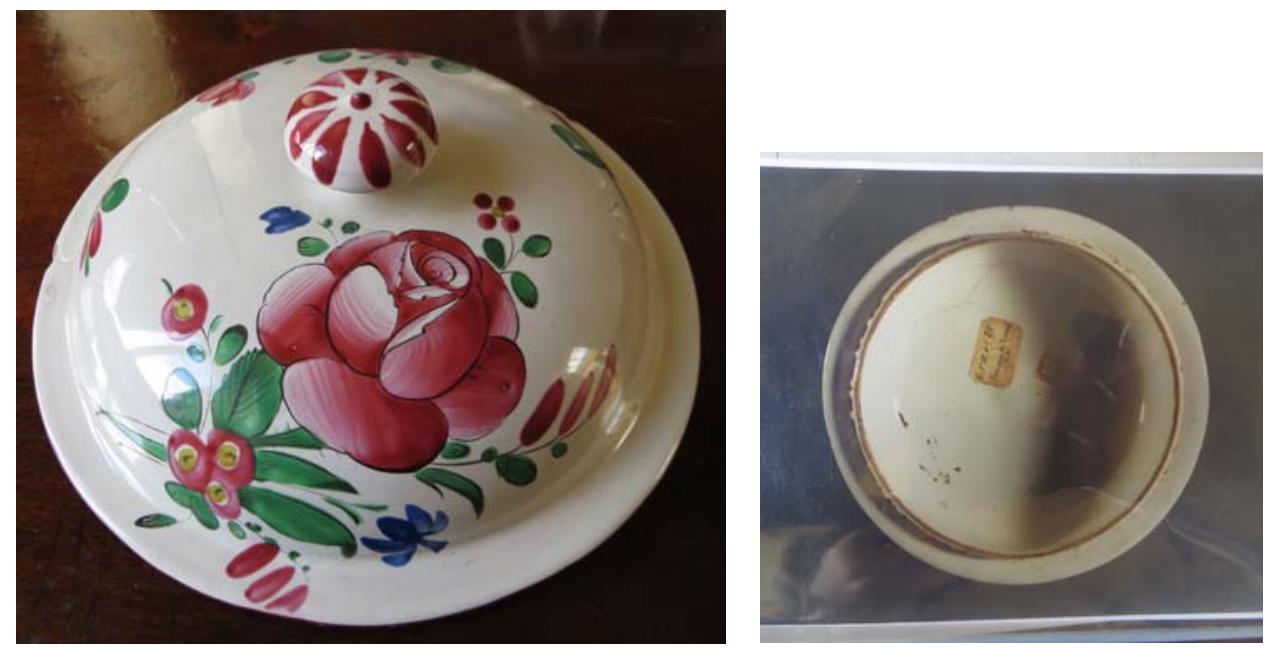

Anais do Museu Paulista. v. 22. n.2. Jul.-Dez. 2014. 

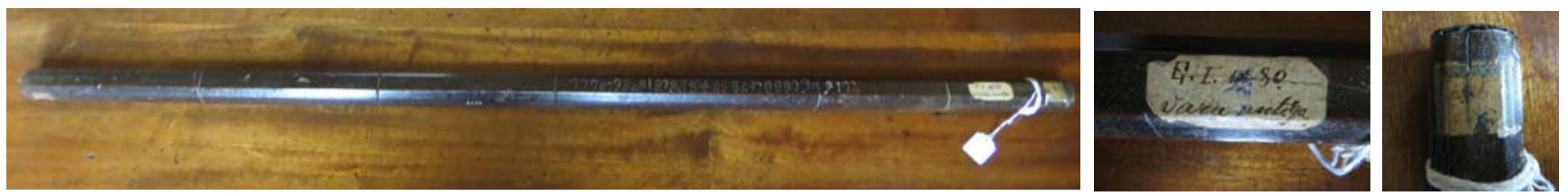

Figuras 34A, 34B e 34C: Vara de aferição, supostamente de 1850. Inscrição: "52 | 53 | 54 | 57 | 666 | 7 | 68 | 69 | 70 | 72

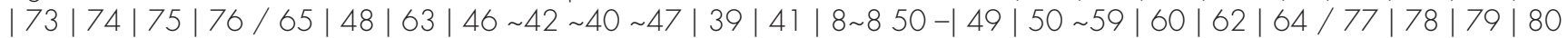
| 81 | 82 | 83 | 84 | 85 | 86 | 87 | 88 | 89 | 90 | 91 | 92". Possui etiqueta fazendo referência à marcação do Catálogo Antigo: E.I - N. 80: "Vara antiga". Outra etiqueta rasgada traz as seguintes palavras: "... numa aferição foi em 16.../ ...rio do Ano do Barão de I...". Essa vara pode ser o objeto mencionado em Raffard (1977, p. 89, 1.ed. 1890): "(..) uma vara de medida que foi do Barão de ltapetininga com aferições antiquíssimas, sendo a primeira de 1666 (...)" (grifos meus). Catalogada por Adilson José de Almeida e Heloisa Barbuy. Catálogo eletrônico do Museu Paulista. Acervo do Museu Paulista/USP, São Paulo.
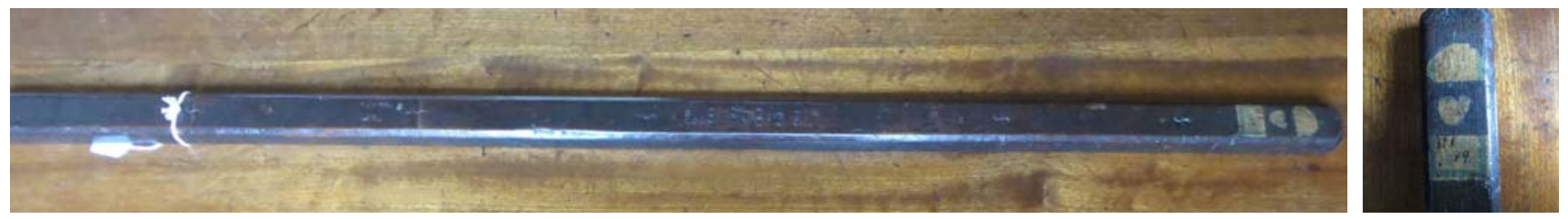

Figuras 35A e 35B: Vara de aferição, cuja primeira aferição é de 1800, e a última, de 1817. Inscrição: "800 | 811 | 812 | 813 | 817". Possui etiqueta fazendo referência à marcação do Catálogo Antigo: E.I - N. 79: "Vara antiga". Catalogada por Adilson José de Almeida. Catálogo eletrônico do Museu Paulista. Acervo do Museu Paulista/USP, São Paulo.

Além dessas duas varas que constam como coleção Sertório, existem mais três varas de aferição no acervo do Museu Paulista.
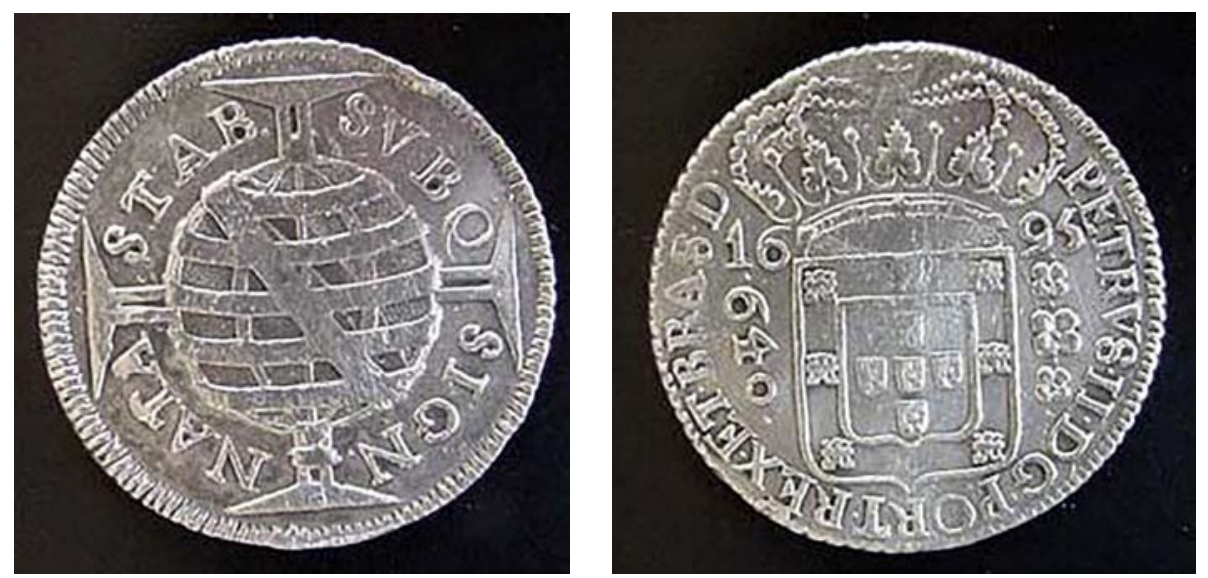

Figuras 36A e 36B: Moeda de prata 640 réis, do século XVII. Fabricante consta como Casa da Moeda da Bahia e desenhista/ gravador, Domingos Ferreira Zambuja. Inscrição na Orla: "Petrvs II. D. G. Port. Eł Bras. D."; no campo, escudo encimado por coroa média, ladeada pela data: "16-95"; à esquerda do escudo, o valor "640" e, à direita, três florões; do outro lado, na Orla: "Subq sign nata stab"; no campo, esfera armilar sobre Cruz da Ordem de Cristo. Na ficha catalográfica, aparece que a data de aquisição da peça foi em 1895, o que contraria a informação de que fazia parte da coleção Sertório. Consta ser uma das peças furtadas do Museu Paulista, em agosto de 2007. Catalogada por Ângela Ribeiro. Catálogo eletrônico do Museu Paulista. Acervo do Museu Paulista/USP, São Paulo.

Annals of Museu Paulista. v. 22. n.2. Jul.-Dec. 2014. 
Não tem figura: Caixa de prata de selo de 1836. No Catálogo Antigo há a marcação: E.I - N. 127: "Caixinha de prata com marca G.J.R.S". As iniciais do objeto podem se referir a Gabriel José Rodrigues dos Santos, uma vez que consta no Catálogo Antigo a presença de bustos com esse nome. Apesar de as iniciais não constarem na ordem G.J.R.S., esse objeto poderia ser o referenciado em Raffard (1977, p. 89, 1.ed. 1890): "(...) caixa do selo da carta do Dr. José Rodrigues Gabriel dos Santos, dada pela Academia de S. Paulo em 1836 (...)". Foi uma das peças furtadas do Museu Paulista, em agosto de 2007. Acervo do Museu Paulista/USP, São Paulo.

Foram ainda encontrados outros 34 objetos que podem ter integrado a coleção Sertório, apesar de não constarem como dela pertencentes no catálogo eletrônico do Museu Paulista. Algumas dessas peças possuem etiquetas - ou restos delas - que fazem referência à numeração do Catálogo Antigo; outras não possuem etiquetas, mas suas descrições correspondem às do Catálogo Antigo ou às encontradas em fontes impressas diversas. A partir desses indícios, é possível inferir que esses outros objetos presentes no acervo do Museu Paulista tenham pertencido à coleção Sertório.

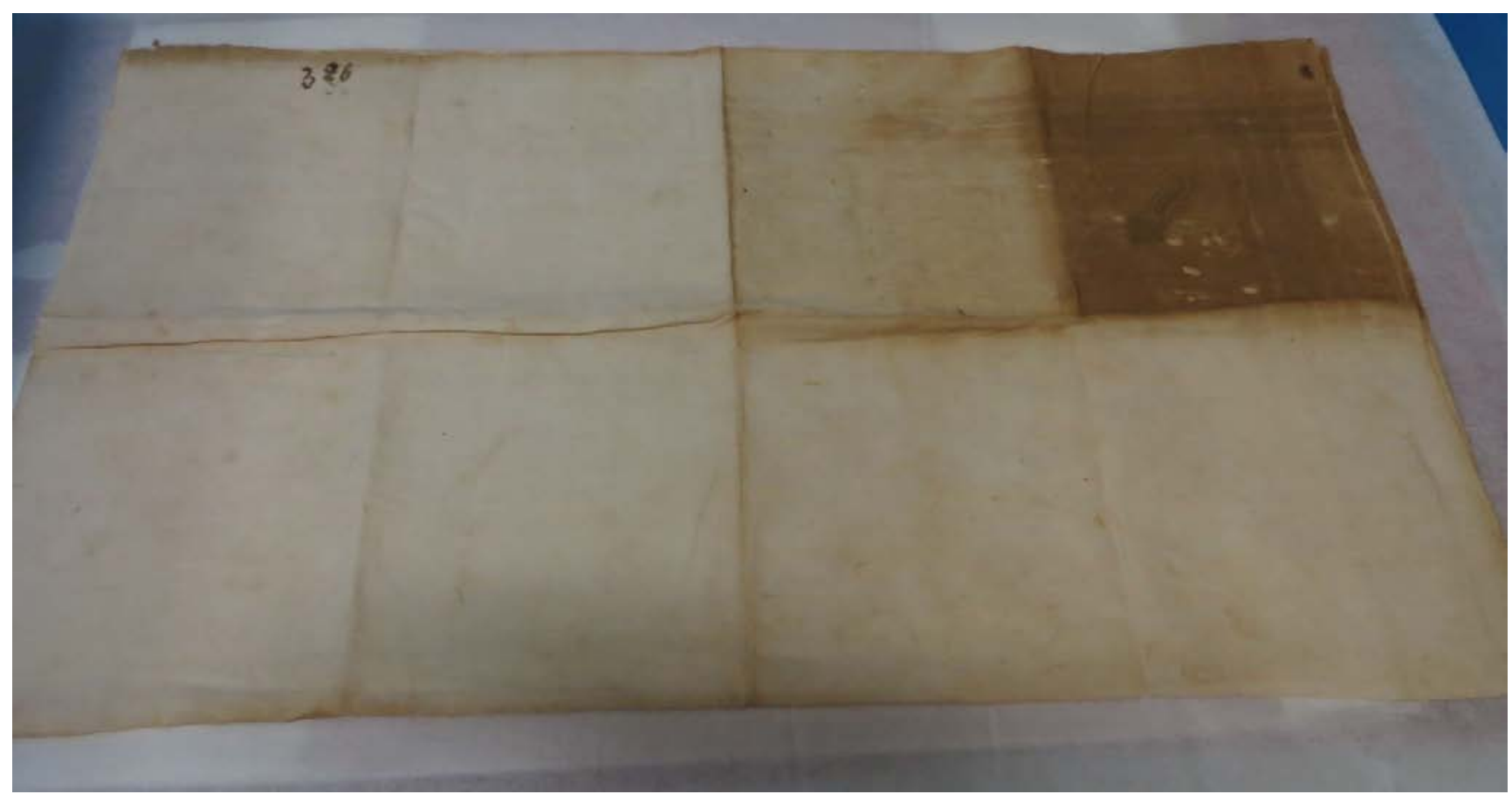

Figura 37: Lenço com "P" bordado encimado pela coroa imperial. Pertenceu a D. Pedro II. Foi deixado por ele na estação de seu nome (hoje Estação Central) em 1886. Há resquícios de etiqueta, e consta no Catálogo Antigo: E.I. - N. 191: "Lenço que foi de D. Pedro II". Raffard (1977, p. 89, 1. ed. 1890) faz menção à peça nesta passagem: "(...) um lenço que S. M. o Imperador deixou na estação D. Pedro II, no dia 5 de novembro de 1886 (este lenço é de linho branco, tem num canto um grande P gótico por baixo da coroa imperial) (...)". Catalogado por Marisa Basso. Catálogo eletrônico do Museu Paulista. Acervo do Museu Paulista/USP, São Paulo. 


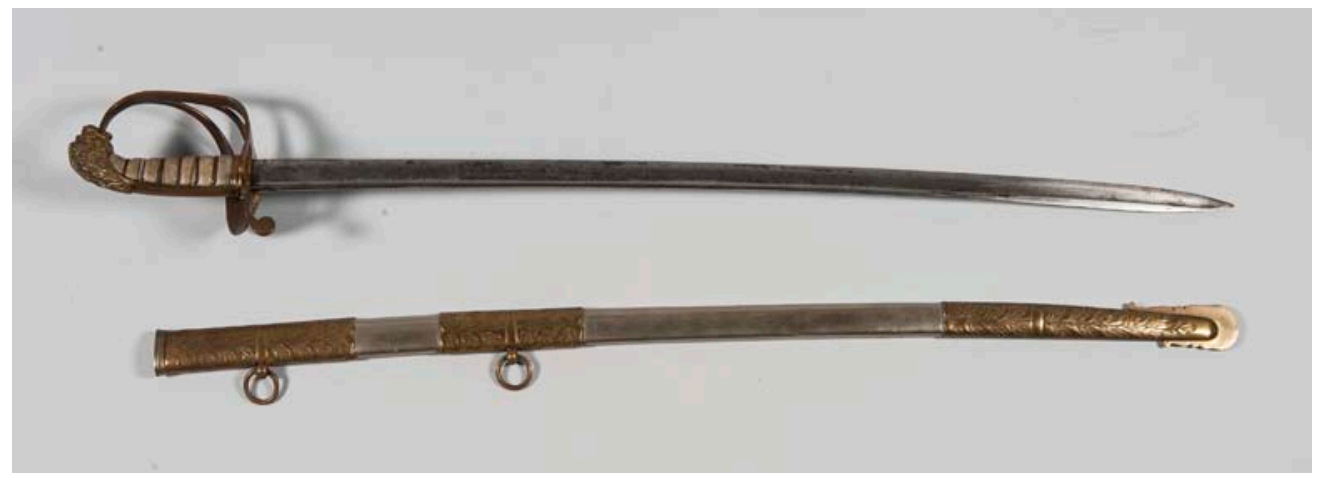

Figura 38: Espada de metal e couro, do século XIX, com cabo com cabeça de leão dourado e brasão do Império. Pertenceu ao Brigadeiro Rafael Tobias de Aguiar. Não possui etiqueta, nem referência no Catálogo Antigo, mas outras fontes apontam a presença desse objeto na coleção Sertório. É possível que a menção de Koseritz (1980, p. 266, 1.ed. 1883) refira-se a essa peça: "(...) a espada ornada de ouro do general Tobias (...)". Raffard também menciona duas espadas que pertenceram ao Brigadeiro Rafael Tobias. Catalogada por Adilson José de Almeida e Heloisa Barbuy. Catálogo eletrônico do Museu Paulista. Acervo do Museu Paulista/USP, São Paulo.
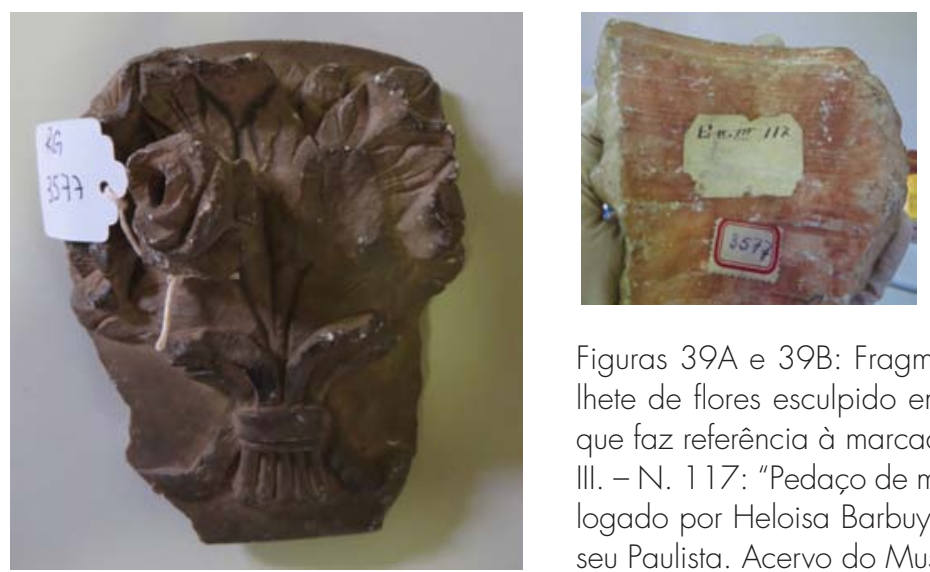

Figuras 39A e 39B: Fragmento de mármore com ramathete de flores esculpido em alto relevo. Possui etiqueta que faz referência à marcação do Catálogo Antigo: E.ll. III. - N. 117: "Pedaço de mármore com escultura". Catalogado por Heloisa Barbuy. Catálogo eletrônico do Museu Paulista. Acervo do Museu Paulista/USP, São Paulo.

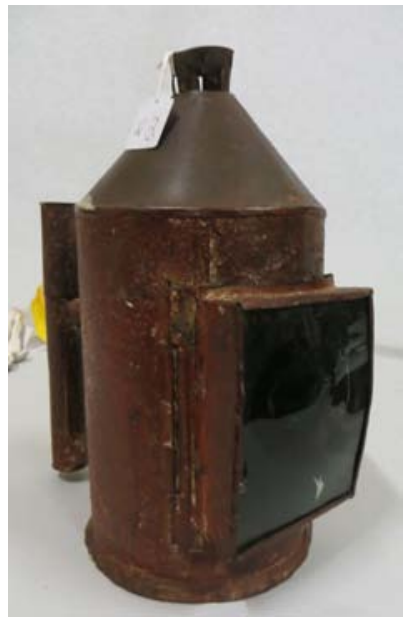

Figura 40: Lanterna no formato de cilindro de metal pintado de vermelho. Pertenceu à lgreja de Santa Rita, Itu. Não possui etiqueta, mas coincide com a marcação do Catálogo Antigo: E.I. - N. 37: "'Lanterna' que foi do primeiro vigário de ltu". Catalogada por Heloisa Barbuy. Catálogo eletrônico do Museu Paulista. Acervo do Museu Paulista/USP, São Paulo. 


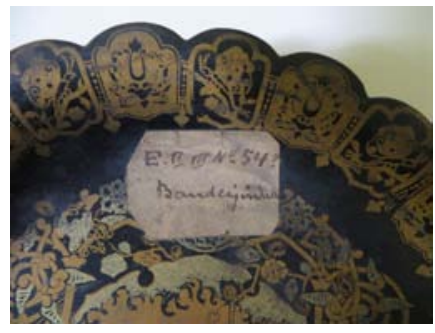

Figuras 41A e 41B: Bandeja pequena de charão. Possui etiqueta que faz referência à marcação do Catálogo Antigo: E.ll. III. - N. 54: "Bandeijinha de charão" - mas na etiqueta o número 54 é seguido por um ponto de interrogação. Na ficha catalográfica consta que o doador foi o Coronel J.J. Raposo Imas consta em ficha anterior 'Oferta - Sr. Attílio Mancini 185-1937')". Catalogada por Joana Biava. Catálogo eletrônico do Museu Paulista. Acervo do Museu Paulista/USP, São Paulo.
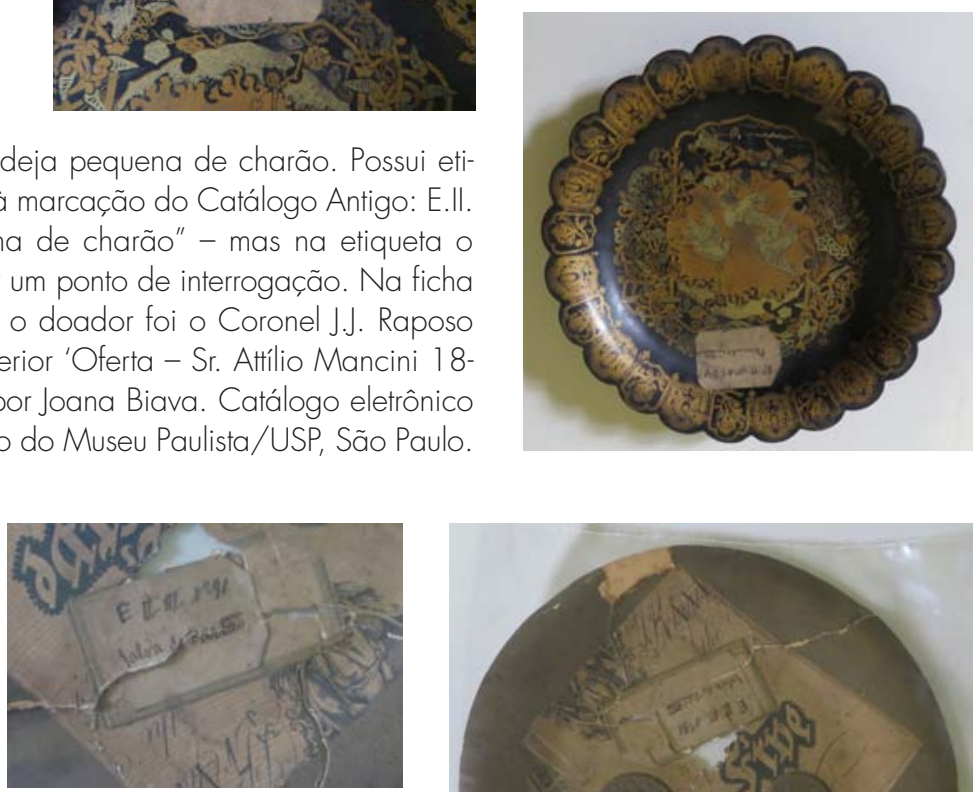

Figuras 42A e 42B: Bandeja de papelão pequena. Possui etiqueta que faz referência à marcação do Catálogo Antigo: E.II.III - N. .91: "Salva de cartão". Na ficha catalográfica consta que o doador foi o Coronel J.J. Raposo. Catalogada por Joana Biava. Catálogo eletrônico do Museu Paulista. Acervo do Museu Paulista/USP, São Paulo.

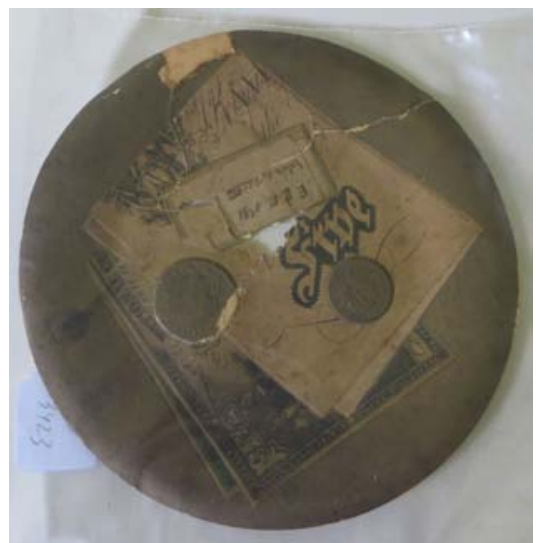

Figura 43: Manteigueira de cerâmica em formato de cesta com tampa com peixes em policromia. Original de Caldas da Rainha, Portugal, possuindo a marca "M. Mafra/ Caldas/ Portugal", com uma âncora, em relevo - Mafra foi uma manufatura de porcelanas criada em 1853, por Manuel Cypriano Gomes Mafra, em Caldas da Rainha, Portugal. Não possui etiqueta, mas a ficha catalográfica faz referência à marcação do Catálogo Antigo: E.II.III. N: 79: "Manteigueira com peixes na tampa". Consta na ficha que o doador foi J.J. Raposo. Catalogada por Joana Biava. Catálogo eletrônico do Museu Paulista. Acervo do Museu Paulista/USP, São Paulo.

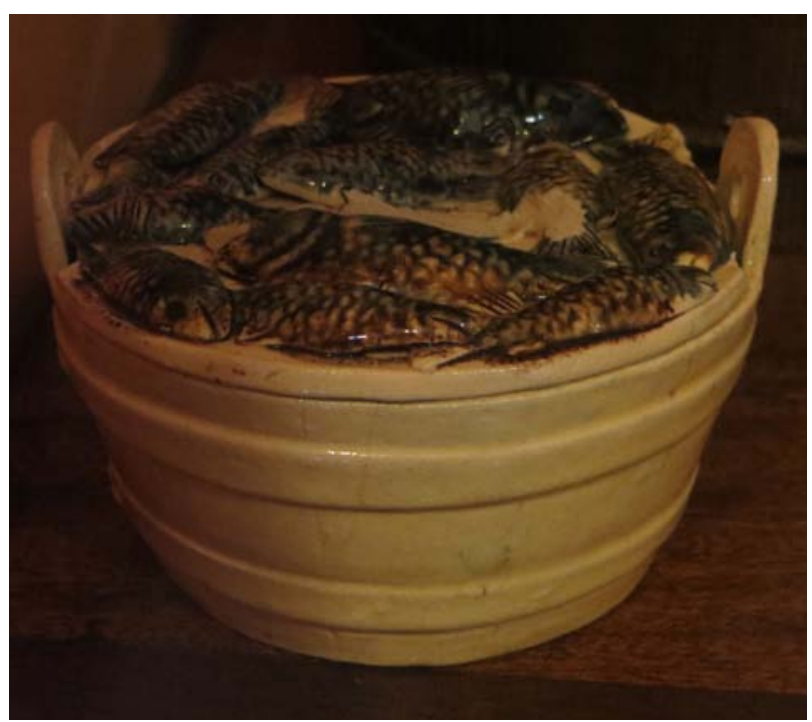




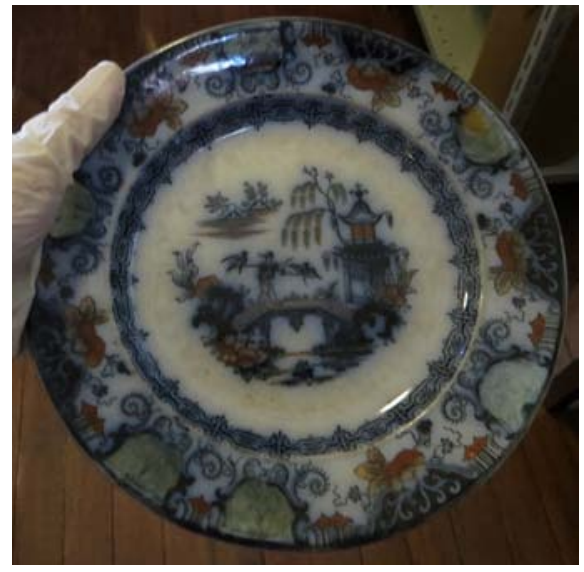

Figura 44: Prato raso de faiança inglesa. Sob o prato, a marca "Kin-shan"; aba com motivos geométricos e florais em azul; ao centro, cena de jovem atravessando uma ponte. Não possui etiqueta, mas consta na ficha catalográfica referência à marcação do Catálogo Antigo: E.II.III. - N. 44: "Prato japonês". Catálogo eletrônico do Museu Paulista. Acervo do Museu Paulista/USP, São Paulo.

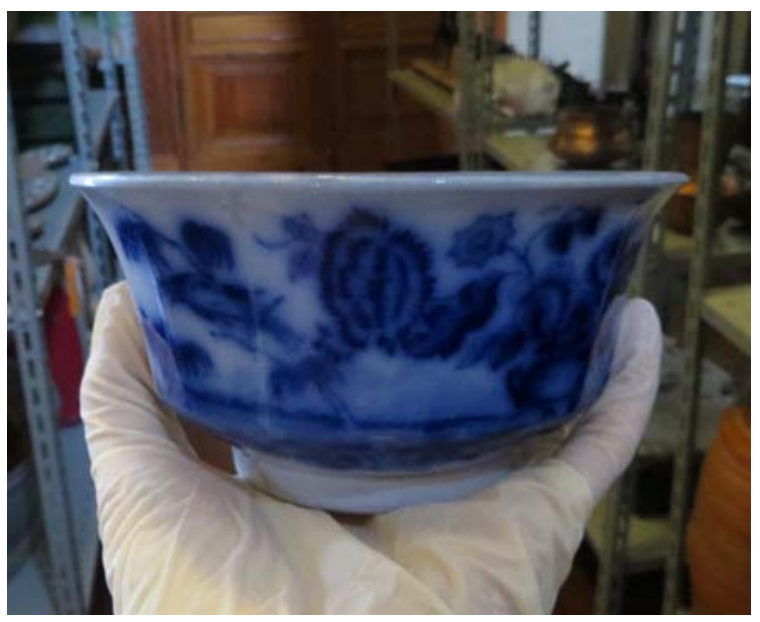

Figura 45: Tigela redonda em porcelana inglesa azul e branca, de origem inglesa, com a marca "Copeland Late Spode" "25" (o fabricante era a Manufatura W.T. Copeland). Não possui etiqueta, mas consta na ficha catalográfica referência à marcação do Catálogo Antigo: E.II.III. - N. 33: "Tijela azul". Consta na ficha que o doador foi J.J. Raposo. Catalogada por Heloisa Barbuy. Catálogo eletrônico do Museu Paulista. Acervo do Museu Paulista/ USP, São Paulo.
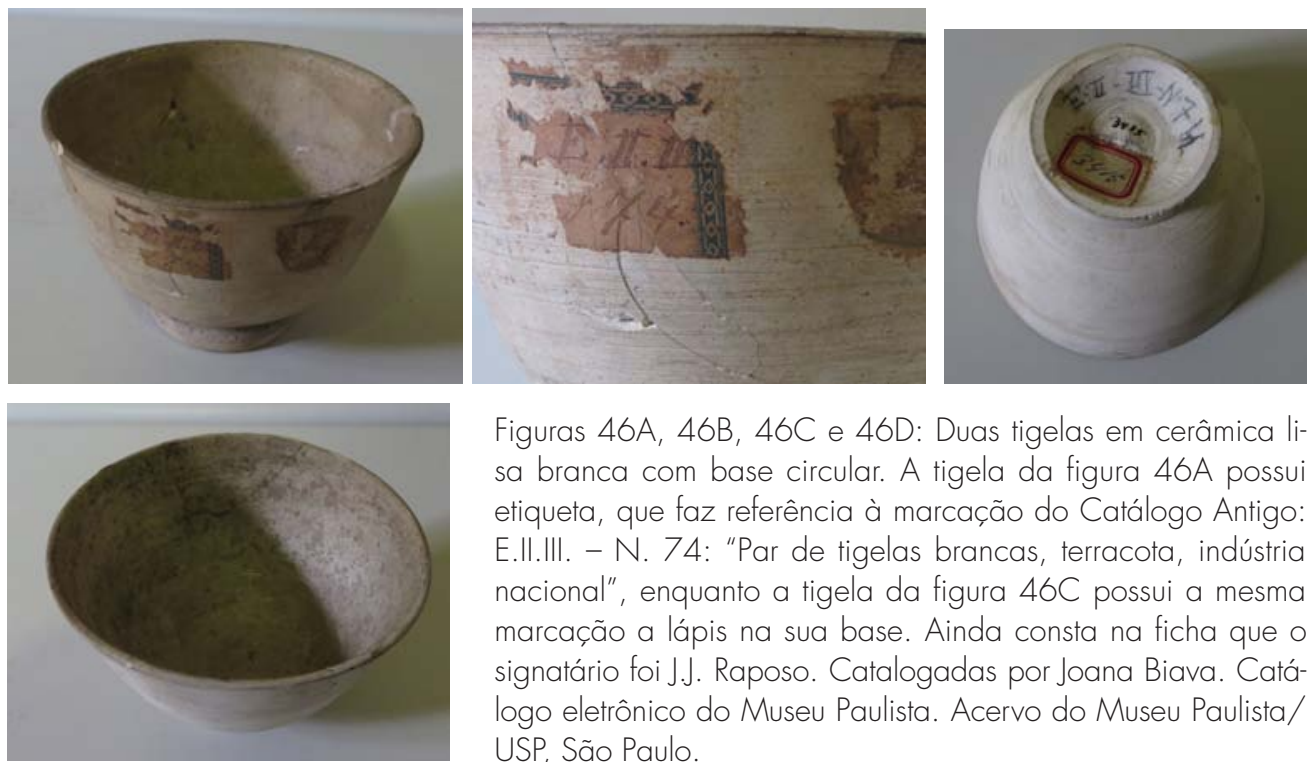

Figuras 46A, 46B, 46C e 46D: Duas tigelas em cerâmica lisa branca com base circular. A tigela da figura $46 \mathrm{~A}$ possui etiqueta, que faz referência à marcação do Catálogo Antigo: E.II.III. - N. 74: "Par de tigelas brancas, terracota, indústria nacional", enquanto a tigela da figura $46 \mathrm{C}$ possui a mesma marcação a lápis na sua base. Ainda consta na ficha que o signatário foi J.J. Raposo. Catalogadas por Joana Biava. Catálogo eletrônico do Museu Paulista. Acervo do Museu Paulista/ USP, São Paulo. 
Figuras 47A e 47B: Tigela em cerâmica lisa rósea com base circular. Possui etiqueta que faz referência à marcação do Catálogo Antigo: E.II. III. - N. 75: "Tigelas (4) avermelhadas, terracota, indústria nacional". Ainda consta na ficha que $\circ$ signatário foi J.J. Raposo. Catalogada por Joana Biava. Catálogo eletrônico do Museu Paulista. Acervo do Museu Paulista/USP, São Paulo.

Figura 48: Xícara e pires de cerâmica. Há parte faltante da asa e grande parte faltante do pires. Não possui etiqueta, mas consta na ficha catalográfica a marcação do Catálogo Antigo: E.ll. III. - N. 61: "Par de xícaras com paisagem". No Museu Paulista, só consta apenas uma xícara. Catalogada por Heloisa Barbuy. Catálogo eletrônico do Museu Paulista. Acervo do Museu Paulista/USP, São Paulo.
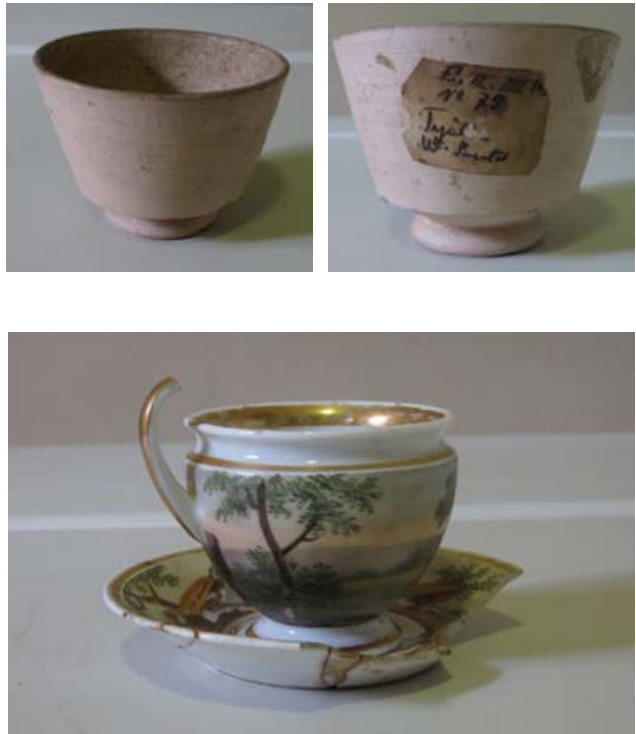

Figura 49: Casaco de veludo marrom; inscrição: "Barão de Tietê". Pertenceu ao Barão do Tietê, José Manuel da Silva (São Paulo, 1793; São Paulo, 27/03/1877). Consta na ficha catalográfica referência à marcação do Catálogo Antigo: E.I. - N. 55: "Casaca que foi do Barão do Tietê". Catalogado por Marisa Basso. Catálogo eletrônico do Museu Paulista. Acervo do Museu Paulista/USP, São Paulo.
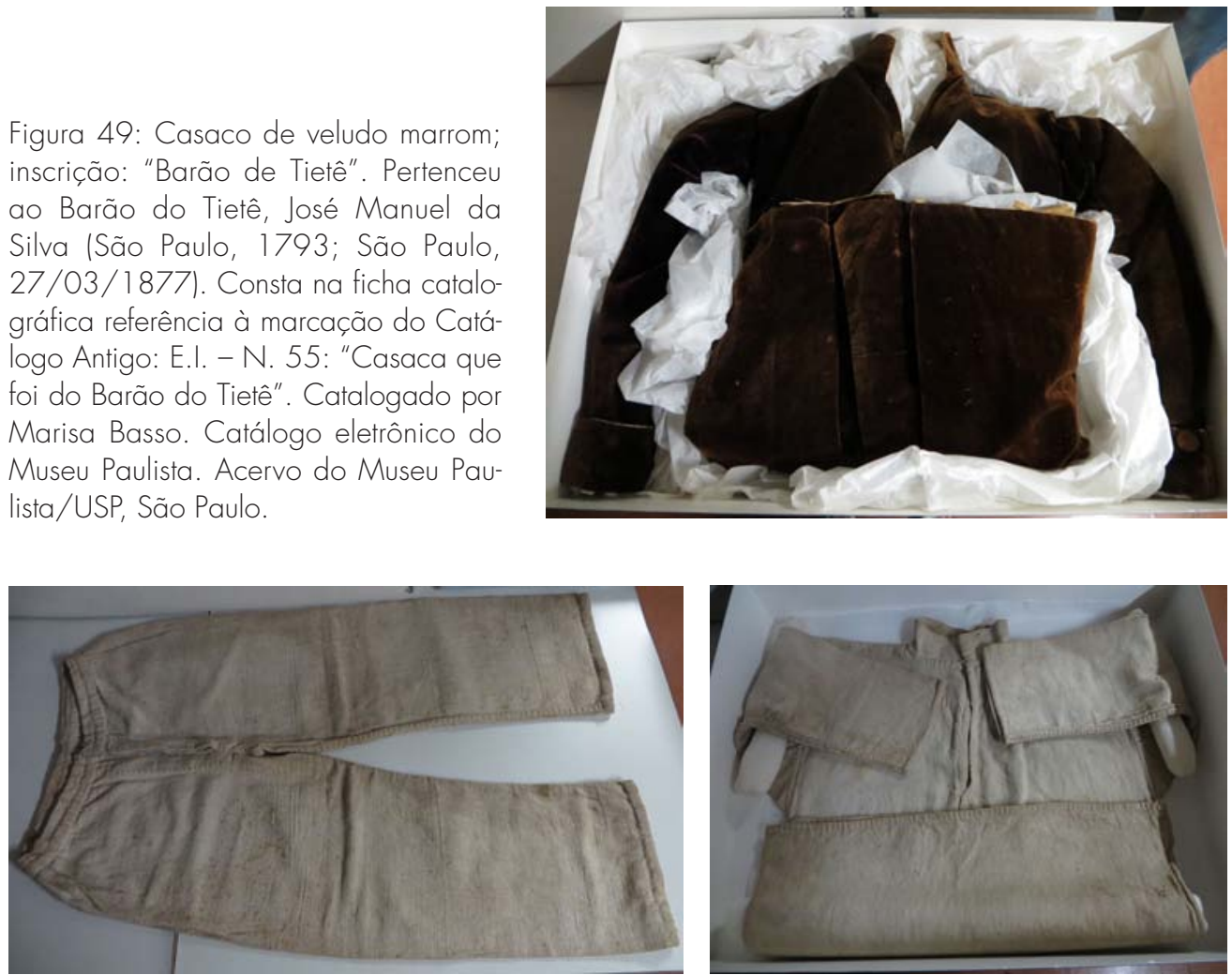

Figuras 50A e 50B: Roupa de escravo, formada por calça e paletó/túnica. Não possui etiqueta, mas é possível que faça referência à seguinte marcação do Catálogo Antigo: E.I. - N. 56: "Jaqueta e calça branca (usado pelo escravo?)". Catálogo eletrônico do Museu Paulista. Acervo do Museu Paulista/USP, São Paulo. 

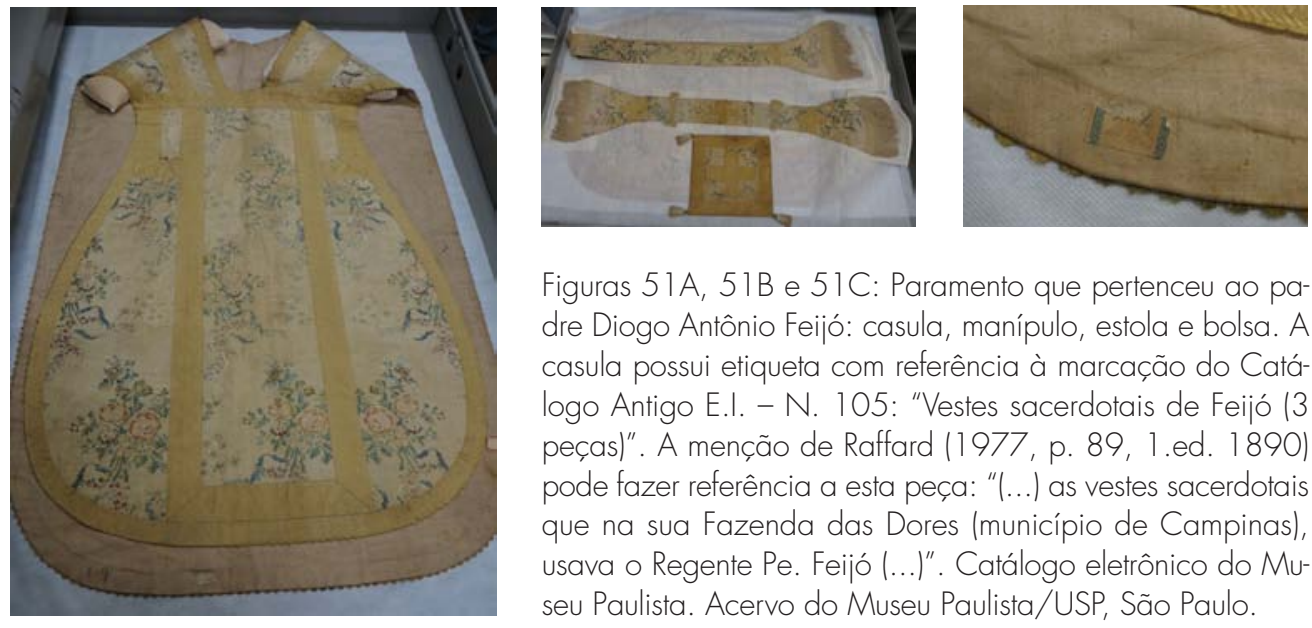

Figuras 51A, 51B e 51C: Paramento que pertenceu ao padre Diogo Antônio Feijó: casula, manípulo, estola e bolsa. A casula possui etiqueta com referência à marcação do Catálogo Antigo E.I. - N. 105: "Vestes sacerdotais de Feijó (3 peças)". A menção de Raffard (1977, p. 89, 1.ed. 1890) pode fazer referência a esta peça: "(...) as vestes sacerdotais que na sua Fazenda das Dores (município de Campinas), usava o Regente Pe. Feijó (...)". Catálogo eletrônico do Museu Paulista. Acervo do Museu Paulista/USP, São Paulo.

Figura 52: Conjunto formado por balança, pesos e caixa de aferição que guarda a balança e conjunto de pesos. Inscrições: (na tampa) "1863/064 / 1859 / $1860 / 1861 / 1857 / 1858 / 54 /$ 1849 / $1850 / 1851 / 52 / 1862 / 8653 /$ $1855 "$ (na lateral) "1848" (na frente) "1856/ $18(2) 7 / 1840 / 1841 / 18(2) 2 / 1843$ / 1847 / 1846 / 1845 / 1844". Pertenceu ao Sr. João Fernandes. Não possui etiqueta, mas descrição e histórico correspondem à marcação do Catálogo Antigo: E.I. -N. 85: "Balança que foi de João Fernandes (Santos)". Catalogada por Heloisa Barbuy. Catálogo eletrônico do Museu Paulista. Acervo do Museu Paulista/USP, São Paulo.

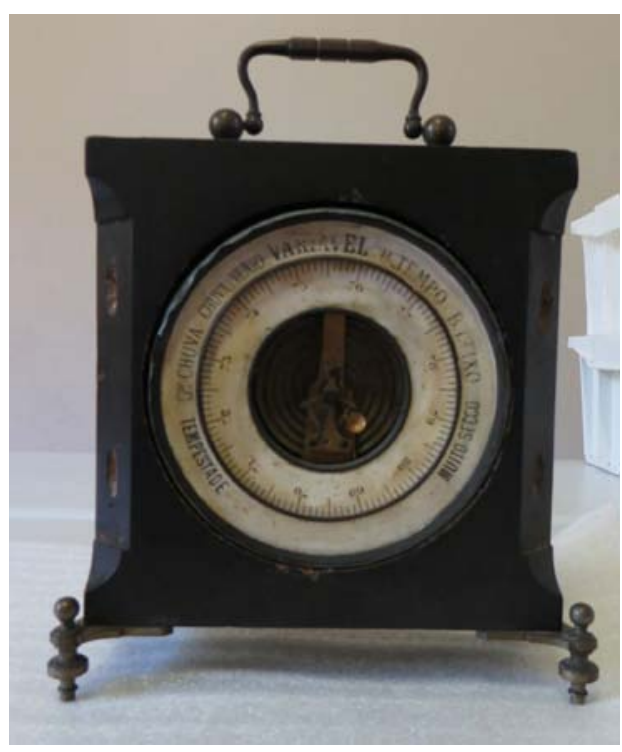

Figura 53: Barômetro aneroide. Caixa quadrada de madeira, com alça e quatro pés de metal. Mostrador redondo. Internamente, caixa redonda com mostrador contendo os mecanismos em metal amarelo. Inscrições: "Tempestade Gde Chuva Chuva e Vento Variável B. Tempo Muito Seco". Não contém etiqueta, mas a descrição corresponde à do Catálogo Antigo: E.II.III N. 267: "Barômetro aneroide". Catalogado por Heloisa Barbuy. Catálogo eletrônico do Museu Paulista. Acervo do Museu Paulista/USP, São Paulo. 
Figura 54: Instrumento de autopenitência de metal e ferro. Não possui etiqueta, mas descrição corresponde às do Catálogo Antigo: E.I. - N. 206: "Flagelário dos jesuítas (disciplina)", e N. 207: "Flagelário dos jesuítas (disciplina)". Koseritz (1980, p. 266, 1.ed. 1883) menciona estas peças: "(...) Ali estão as disciplinas (instrumentos de flagelação) dos velhos conventos de São Paulo (...)". Catálogo eletrônico do Museu Paulista. Acervo do Museu Paulista/USP, São Paulo.
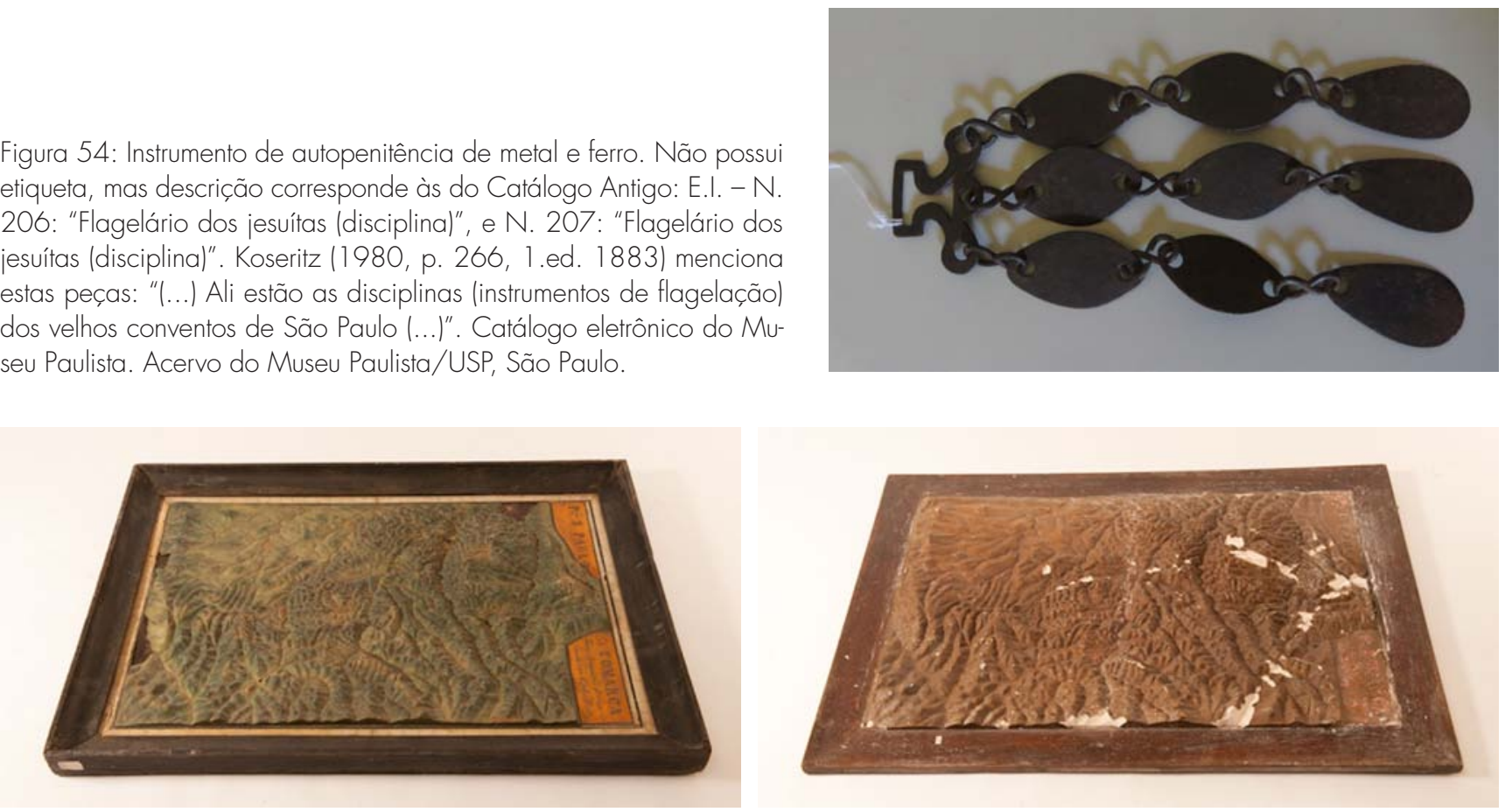

Figuras 55A e 55B: Modelos topográficos. A figura 55A, à esquerda, constitui relevo em gesso sobre base de metal e moldura de madeira; inscrições: "PCIA S. PAULO $5^{\circ}$ COMARCA TERMO BRAGANÇA E ATHIBAIA ETC LEGENDADO POR CARLOS RATH". A figura 55B, à direita, consiste em relevo em gesso sobre base de cimento e moldura de madeira; inscrições: "PCIA S. PAULO $2^{a}$ COMARCA (...)". Não possuem etiquetas, mas descrições correspondem às marcações do Catálogo Antigo: E.I. - N. 100: "Quadro 'orográfico' da comarca de Bragança pelo Dr. Ratto" e N. 10 1: "Quadro 'orográfico' da comarca de Bragança pelo Dr. Ratto". Segundo informações coletadas no acervo de Carl Rath, no Instituto Martius Staden, Rath desenhou um mapa em relevo da região de Bragança e Atibaia em 1853. Ele ainda possuía uma coleção de pedras e minérios recolhidos em expedições por São Paulo. Inicialmente, ele a teria guardado na sua própria casa, mas depois a doou para o Museu Sertório. (Disponível em: <http://crossmedia.tv/crossmedia/carlrath/menu.swf>. Acesso em: 11 fev. 2014). Raffard (1977, p. 89, 1.ed. 1890) menciona estas peças na seguinte passagem: "(...) uma planta em relevo do terreno de Bragança e Atibaia, trabalho de Carlos Rath (...)". Catalogados por Heloisa Barbuy. Catálogo eletrônico do Museu Paulista. Acervo do Museu Paulista/USP, São Paulo.

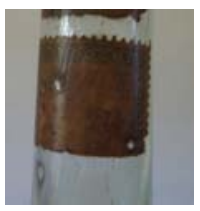

Figura 56: Garrafa com figuras de osso, sendo possivelmente um objeto devocional. No interior há estrutura em formato de pináculo ou torre; base em madeira, com duas traves entrecruzadas de cujo centro parte o pináculo esculpido em osso, com suporte cruciforme, a meia-altura, e em cujas extremidades estão encaixadas, de modo alternado, figurinhas e cálices. Na base, encaixam-se quatro coruchéus também de osso. A garrafa traz no corpo, em relevo, a inscrição "Água de Flori/Murray y Lanman/ Droguistas/ New York". Possui etiqueta com inscrição: "E.II.III 20[...]", podendo fazer referência à marcação do Catálogo Antigo: E.II.III. - N. 208: "Garrafa (duas) com cruz dentro". Catalogada por Heloisa Barbuy. Catálogo eletrônico do Museu Paulista. Acervo do Museu Paulista/USP, São Paulo.

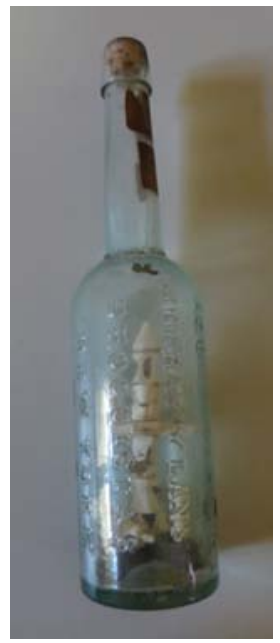



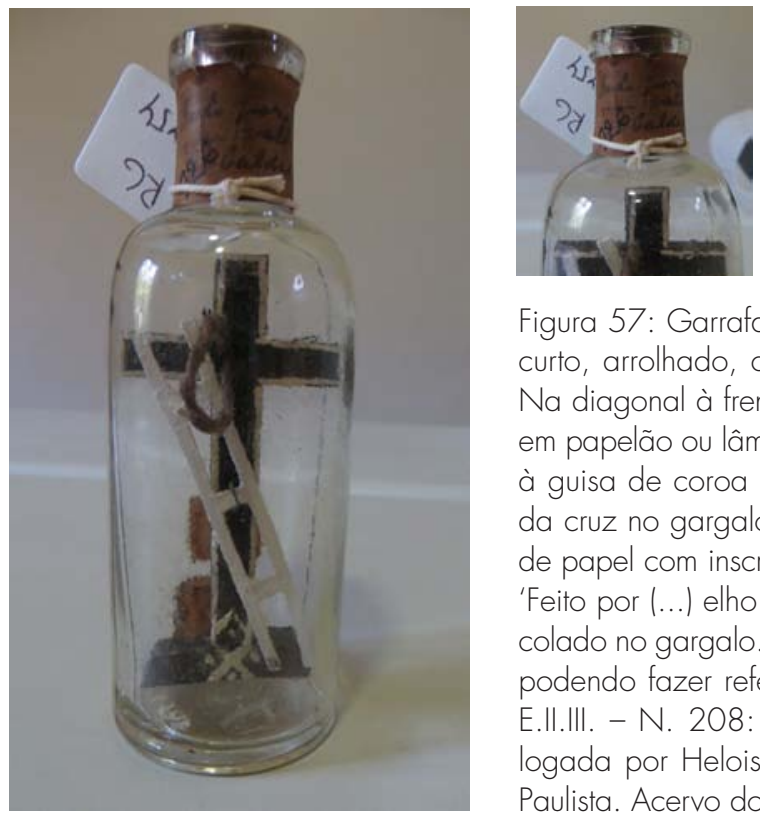

Figura 57: Garrafa de vidro branco, cilíndrica, com gargalo curto, arrolhado, contendo no interior crucifixo de madeira. Na diagonal à frente da cruz, uma escada branca recortada em papelão ou lâmina de madeira. Um aro torcido em papel, à guisa de coroa de espinhos, pende da junção das traves da cruz no gargalo, externamente, está colado um retângulo de papel com inscrição manuscrita (v. Inscrições) / Inscrições: 'Feito por (...) elho (...) Caldas 926', manuscrito sobre papel colado no gargalo. Possui etiqueta com inscrição: "E.II. III [...]", podendo fazer referência à marcação do Catálogo Antigo: E.II.III. - N. 208: "Garrafa (duas) com cruz dentro". Catalogada por Heloisa Barbuy. Catálogo eletrônico do Museu Paulista. Acervo do Museu Paulista/USP, São Paulo.
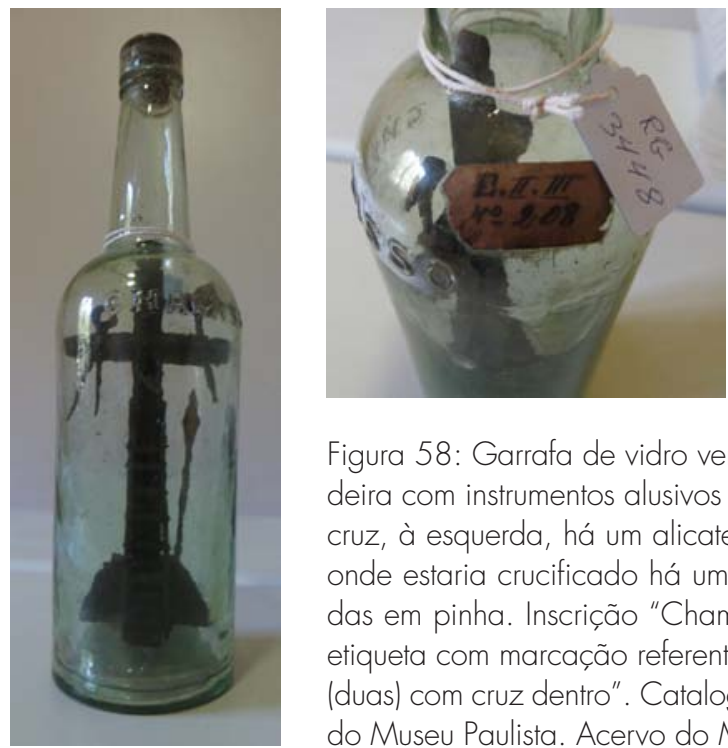

Figura 58: Garrafa de vidro verde-claro contendo no interior crucifixo de madeira com instrumentos alusivos à crucificação de Cristo. Na face anterior da cruz, à esquerda, há um alicate ou tenaz e na direita um martelo. No ponto onde estaria crucificado há um grampo de metal. Ponteiras da cruz recortadas em pinha. Inscrição "Chamisso" em relevo no corpo da garrafa. Possui etiqueta com marcação referente à do Catálogo Antigo E.II.III.208. "Garrafa (duas) com cruz dentro". Catalogada por Heloisa Barbuy. Catálogo eletrônico do Museu Paulista. Acervo do Museu Paulista/USP, São Paulo.

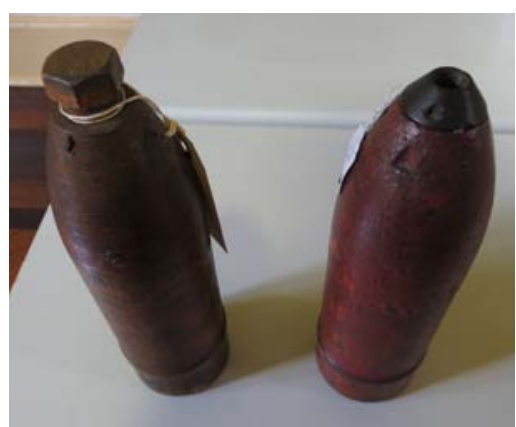

Figura 59: Munição: projéteis para artilharia. $\bigcirc$ projétil à esquerda foi pintado com zarcão e contém inscrição "O". O outro foi pintado de vermelho e contém a inscrição: "5". Não possuem etiqueta, mas podem corresponder à referência do Catálogo Antigo: E.I. - N.36: "Coleção de 20 projéteis da Fortaleza de Santos". Catálogo eletrônico do Museu Paulista. Acervo do Museu Paulista/USP, São Paulo. 


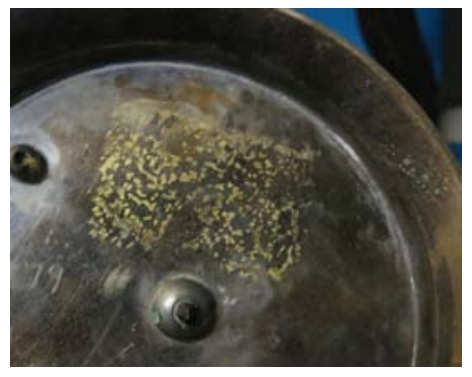

Figura 60: Castiçal em formato de duas bengalas cruzadas e uma cartola. Possui traços de etiqueta, mas não é possível identificar à qual marcação se refere. Catálogo eletrônico do Museu Paulista. Acervo do Museu Paulista/USP, São Paulo.

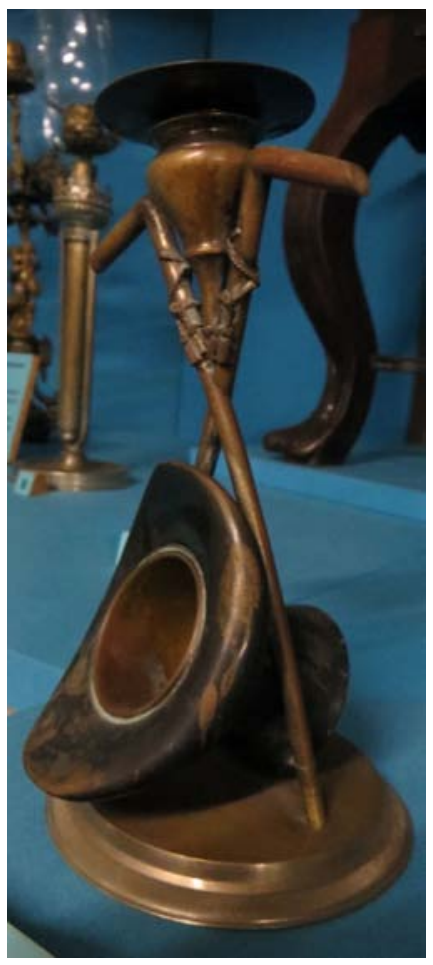

Figura 61: Palmatória de madeira do século XIX. Não possui etiqueta, mas pode se referir à marcação do Catálogo Antigo: E.I. - N. 77: "Palmatória de fazenda". Catálogo eletrônico do Museu Paulista. Acervo do Museu Paulista/USP, São Paulo.

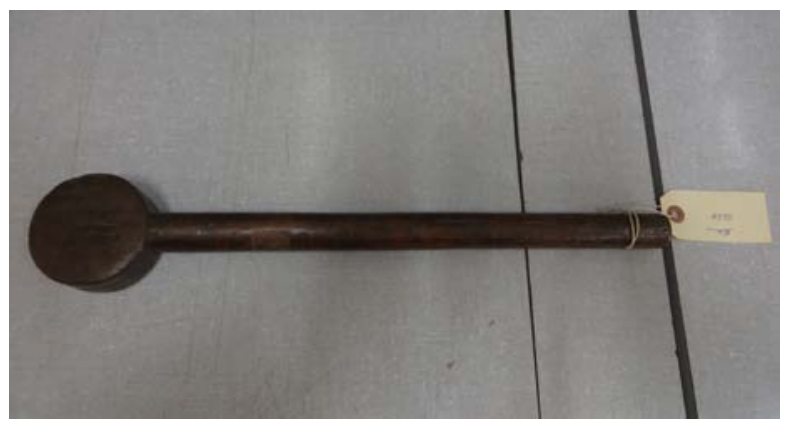

Não tem figura: Tigela redonda em porcelana azul e branca, de origem inglesa, com a inscrição "Copeland Late Spode" "25" (o fabricante era a Manufatura W.T. Copeland). Consta na ficha catalográfica que essa peça não foi localizada desde 1991. A ficha faz referência à marcação do Catálogo Antigo: E.II.III. - N. 58; no entanto, essa notação não está correta uma vez que o objeto E.II.III. - N.58 corresponde a "Xícara e pires antigos dourados". Consta doação de J.J. Raposo. Catalogada por Joana Biava. Catálogo eletrônico do Museu Paulista. Acervo do Museu Paulista/USP, São Paulo.

Os dois objetos abaixo, apesar de provavelmente não terem feito parte da coleção Sertório, foram adquiridos quando o acervo já fazia parte do Museu do Estado e antes da inauguração do Museu Paulista. 

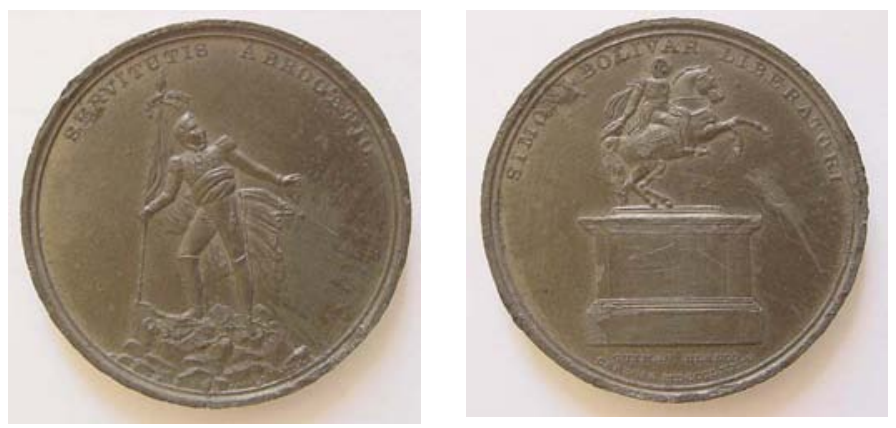

Figuras 62A e 62B: Medalha Inauguração da Estátua de Simón Bolívar. Medalha feita de estanho. ANV/Na Orla superior: "Simon Bolivar Libertatori" no campo: Monumento ao General em Caracas. No exergo a legenda: "Caracas MDCCCLXXIV". Acima da legenda, em linha horizontal: "Guzman Blanco". Moldura larga. REV/ Na orla superior: "Servitus Abrogatio" no campo: Sobre um rochedo, Simon Bolívar com bandeira na mão direita, olhando à direita. É possível que a seguinte notícia de jornal faça menção à peça: "Museu do Estado/O ilustre paulista dr. Manoel Martins Bonilha ofereceu ao nosso museu quatro mimos muito interessantes e curiosos (...)/ Uma medalha representando em uma face o general Bolívar subindo a cordilheira dos Andes e na outra a sua estátua que se acha colocada na praça principal da cidade de Caracas, capital federal dos Estados Unidos da Venezuela. (...)". O Estado de S. Paulo $(07$ ago. 1891 , p. 2). Catalogada por Ângela Ribeiro. Catálogo eletrônico do Museu Paulista. Acervo do Museu Paulista/USP, São Paulo.

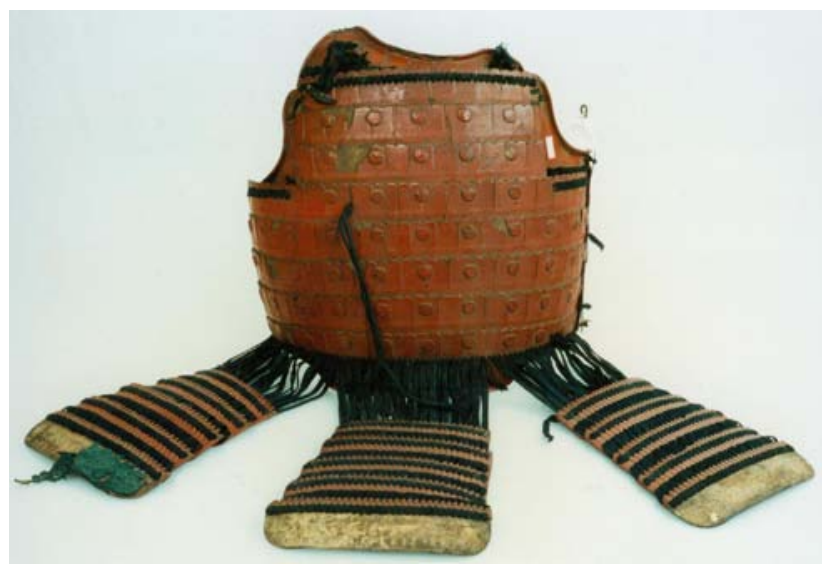

Figura 63: Traje samurai de seda, feltro, tecido celulósico, algodão e linho, metal. É provável que a esta notícia de $O$ Estado de S. Paulo (02 ago. 1891, p. 2) faça referência à peça: "Museu do Estado - $O$ sr. Jacques Hesselring ofereceu ao Museu do Estado uma interessante e completa armadura de guerreiro japonês, que consta de couraça, capacete, máscara de ferro e outras peças". Catálogo eletrônico do Museu Paulista. Acervo do Museu Paulista/USP, São Paulo.

Muitos dos 76 objetos encontrados ainda hoje no acervo do Museu Paulista pertenceram a alguma personalidade histórica importante, ou tomaram parte de algum evento ou cenário relevante para a história não só de São Paulo, mas também do Brasil. É o caso, por exemplo, da "pedra de dominó do ditador paraguaio Solano López", "o lenço de D. Pedro II", "lanterna que pertenceu à Igreja de Santa Rita, Itu", entre outros. O próprio Sertório procurou recolher objetos que fizessem parte da "História Pátria". Esse aspecto também fazia parte do projeto para o Museu Paulista que teve, sob a direção de Hermann von Ihering, suas origens baseadas no modelo de um museu de história naturalo4, como já comentado, incluindo a história nacional.

$64 \mathrm{O}$ artigo $3^{\circ}$ do regulamento do Museu Paulista afirma que "Além das coleções de ciências naturais, haverá no Museu uma seção destinada a História Nacional e especialmente dedicada a colecionar e arquivar documentos relativos ao período de nossa independência política". Apud Fábio Rodrigo Moraes (2008). O artigo de Moraes mostra, inclusive, como as coleções de história foram incrementadas durante a gestão de Ihering, embora fossem secundárias em relação às coleções de ciências naturais. 
65. Cf. Ulpiano Bezerra de Meneses (1994, p. 18).

66. Cf. Ulpiano Bezerra de Meneses (1994, p. 19).
Essas peças se inserem na categoria sociológica de objeto histórico. Segundo Ulpiano Bezerra de Meneses, é o tipo de item que prevalece em muitos museus, e que se caracteriza não por aspectos inerentes a ele, mas por um sentido adquirido pela

contaminação externa com alguma realidade transcendental (...) São objetos singulares e auráticos, na expressão benjaminiana ou, mais precisamente, não-fungíveis. Não poderiam ser substituídos por cópias ou por objetos de atributos equivalentes. São excluídos de circulação e não só têm seu valor de uso drenado, como trazem para qualquer uso prático eventual a pecha do sacrilégio ${ }^{65}$.

Tendo isso em mente, é um tanto intrigante se deparar com uma diversidade de peças "comuns", entre pires, tijelas, pratos, bandejas, cadeiras e garrafas de vidro ornamentadas, que, aparentemente, não possuem nenhuma ligação com alguma figura, algum evento ou local tidos como relevantes na história, nem detêm algo de "notável" à primeira vista. Essa, talvez, seja a característica mais marcante de algumas das peças que restaram da coleção Sertório no Museu Paulista: seu caráter comum, de uso cotidiano. Qual seria a razão para tais objetos estarem na coleção?

Como Sertório não deixou nenhum escrito conhecido sobre suas escolhas ao coletar essas peças, só é possível especular sobre a questão. Talvez ele simplesmente tenha achado beleza em algum objeto e, por isso, resolvera guardálo; alguém pode ter doado alguma peça que the parecia digna de ser preservada e exposta num museu e Sertório aquiesceu; ou o próprio objeto poderia ter algum significado para o colecionador que para nós é desconhecido - essas hipóteses podem parecer, a princípio, por demais simples, mas não devem ser descartadas pela aparente banalidade, pois são plausíveis, ainda mais quando se tenta discernir as intenções por trás das escolhas de um colecionador. Outra ideia é que Sertório procurou conservar peças apenas porque eram "antigas", e essa antiguidade em si já seria um valor aos seus olhos, como a marca de um tempo passado que, de forma ambígua, se "materializa" no presente. Como explica Meneses:

objeto antigo, obviamente, foi fabricado e manipulado em tempo anterior ao nosso, atendendo às contingências sociais, econômicas, tecnológicas, culturais, etc. etc. desse tempo. Nessa medida, deveria ter vários usos e funções, utilitários ou simbólicos. No entanto, imerso na nossa contemporaneidade, decorando ambientes, integrando coleções ou institucionalizado no museu, o objeto antigo tem todos os seus significados, usos e funções anteriores drenados e se recicla, aqui e agora, essencialmente, como objeto-portador-de-sentido. Assim, por exemplo, todo eventual valor de uso subsistente converte-se em valor cognitivo o que, por sua vez, pode alimentar outros valores que o passado acentua ou legitima. Longe, pois, de representar a sobrevivência, ainda que fragmentada, de uma certa ordem tradicional, é do presente, indica Jean Baudrillard, que ele tira sua existência. E é do presente que deriva sua ambiguidade 66 . 
É importante observar que, para este artigo, esses objetos fazem parte da própria história do Museu Paulista. A partir desse ponto, é possível examinar a importância que o Museu Sertório teve na sua época, quando ainda não existiam museus "oficiais" em São Paulo. Como documentos, os objetos encontrados no acervo do Museu Paulista vislumbram o que era a coleção Sertório. Nesse sentido, citando Meneses:

O que faz de um objeto documento não é, pois, uma carga latente, definida, de informação que ele encerre, pronta para ser extraída, como o sumo de um limão. $\bigcirc$ documento não tem em si sua própria identidade, provisoriamente indisponível, até que o ósculo metodológico do historiador resgate a Bela Adormecida de seu sono programático. É, pois, a questão de conhecimento que cria o sistema documental. O historiador não faz o documento falar: é o historiador quem fala e a explicitação de seus critérios e procedimentos é fundamental para definir o alcance de sua fala. Toda operação com documentos, portanto, é de natureza retórica ${ }^{67}$.

Com isso, não surpreende que esses objetos tenham permanecido no Museu Paulista, instituição que, ao longo da sua trajetória, foi tomando uma conformação de museu histórico. As peças mostradas são alguns dos objetos históricos que faziam parte da coleção de História Pátria do Museu Sertório, ainda que a coleção histórica do museu do coronel fosse maior. Contudo, foram esses itens que sobreviveram ao longo do tempo e puderam ser recuperados. É bem possível que ainda existam outros objetos do Museu Sertório ainda não identificados como tais no Museu Paulista. Algumas peças podem não ter sobrevivido aos efeitos do tempo, enquanto outras podem ter sido transferidas para outros museus, já que - Museu Paulista deu origem a outras instituições museológicas a partir do desmembramento das suas coleções, como o Museu Zoologia e o Museu de Arqueologia e Etnologia da Universidade de São Paulo. É bastante provável, portanto, que alguns dos objetos da coleção Sertório, classificados sob tipologias baseadas nas ciências naturais e na antropologia, possam fazer parte do acervo desses outros estabelecimentos.

coronel Joaquim Sertório era uma figura proeminente na sociedade paulista, mantendo vínculos com homens importantes do período. Inicialmente, fez carreira na Guarda Nacional para depois se lançar na vida política, entre 1869 e 1882. $\bigcirc$ coronel foi casado com Maria Ribas Sertório, com quem não teve filhos. Homem rico e de posses - sendo proprietário, inclusive, de muitos imóveis -, comerciante, Sertório tinha os meios materiais para acumular uma coleção de objetos. Após deixar a política, parece se dedicar quase integralmente ao seu museu, ganhando dinheiro através de transações imobiliárias ${ }^{68}$ e da formação de uma casa de comissões de café e outros gêneros em sociedade com a firma Valencio Leomil \& C. e dr. Francisco de Assis Peixoto Gomide69. Em 1890 vendeu suas coleções para o conselheiro Francisco de Paula Mayrink, vindo a falecer em 05 de dezembro de 190570 .
67. Idem, p. 21.

68. Informações sobre registros de vendas imobiliárias e quitações de hipoteca se encontram em Correio Paulistano, 10 fev. 1888, p. 2; 14 fev. 1903, p. 2; 21 mar. 1903 , p. 3; 20 maio 1903 , p 3; 02 out. 1903 , p. 1 ; $1^{\circ}$ Cartório de Notas da Capital Livro de Outorgas, n. 101, pp. 8-9; $2^{\circ}$ Cartório de Notas da Capital, Livro de Outorgas $\mathrm{n}^{\circ} 82$.

69. A Provincia de S. Paulo, 19 set. 1884. É interessante destacar que Peixoto Gomide era cunhado de Sertório, que era casado com Maria Ribas Sertório, irmã de Gomide.

70. Outras informações sobre a biografia do Coronel Sertório serão abordadas em futuro artigo. 
71. Cf. Correio Paulistano (27 set. 1884, p. 1).

72. O Museu Nacional também recebia uma série de doações, que era incentivada "por meio dos constantes pedidos oficiais às províncias; da publicação dos nomes dos doadores nos relatórios do museu e nos jornais da Corte; e mesmo mediante materiais específicos de que necessitavam os diretores para seus estudos", cf. Maria Margaret Lopes (1997, p. 165)

73. Cf. Correio Paulistano (07 nov. 1886, p. 1).

74. Cf. A Provincia de $S$. Paulo (04 maio 1886, p. 2).
Sobre a formação do Museu Sertório, ainda não está totalmente claro como o coronel reuniu uma coleção tão variada, nem quais eram os critérios de escolha das peças. No entanto, a partir das notícias publicadas na imprensa durante as décadas de 1880 e 1890, é possível compreender algumas das formas pelas quais ele coletava os objetos para o seu museu.

Em 1884, Sertório enviou a vários órgãos da imprensa e a "diversos cavalheiros" da Província de São Paulo a seguinte circular:

IIIm. Sr. - Tendo em vista franquear o meu museu ao público e querendo completar o mais possível as minhas coleçães de objetos da História Pátria e História Natural desta província, dirijo-me a v.s. pedindo que me auxilie nesta tarefa, cujo fim especial é a instrução, oferecendo à vista de todos, as nossas riquezas naturais.

Todos os objetos de História Natural, como sejam animais, pássaros, plantas, frutas e pedras, assim como também artefatos, ossos e crânios das tribos indígenas, inclusive qualquer outro objeto de antiguidade concernente à história de nosso país, será sempre aceito com o maior prazer e reconhecimento.

Ponderando a v.s. que as despesas de transporte e condução serão satisfeitas por mim, tenho a honra de desde já agradecer a v.s. subscrevendo-me.

Drv.s.

Att. ${ }^{\circ}$ ven. ${ }^{\circ}$ e obr. ${ }^{\circ}$

JOAQUIM SERTÓRIOI.

Portanto, Sertório pediu auxílio na empreitada de completar as suas coleções através de doações, no que foi amplamente atendido, conforme reportado pela imprensa. Era comum que algumas doações fossem noticiadas ${ }^{72}$, como itens de caráter antropológico:

sr. dr. Braulio Urioste, mandando proceder a uma escavação em terrenos sitos à rua do Senador Florêncio de Abreu, nesta capital, encontrou um interessante colar feito de dentes de mico (jacchus argentatus?) [sic] dispostos com certa arte em tecido de fibras de tucum.

Este adereço indígena, apesar de permanecer enterrado por tantos anos, como é de presumir-se, acha-se em perfeito estado de conservação.

sr. dr. Urioste ofereceu-o ao sr. Motta Junior que, por sua vez, enviou ao Museu Sertório onde se acha exposto ${ }^{73}$.

Fósseis também foram oferecidos ao museu:

"Fóssil - Ao Museu Sertório ofereceu o sr. Motta Junior, redator do Rio Branco de Pirassununga, entre outros espécimes curiosos um fóssil que apresenta a configuração de um lagarto, de tamanho descomunal ${ }^{74}$.

Foi, inclusive, durante uma visita de D. Pedro ll ao Museu Sertório, que um homem ofereceu um gavião para fazer parte da coleção: 
Na ocasião da visita [do Imperador D. Pedro II] apresentou-se o sr. José Leite da Costa Sobrinho, oferecendo ao museu enorme gavião (falco nisus), de plumagem cinzenta e branca com pinturas pretas e variadas em todo o corpo.

O sr. José Leite matou esta ave de rapina, a tiro, na serra da Cantareira e disse que ela era conhecida na província pelo nome de águia real.

Esta denominação parece imprópria, porquanto a águia real não habita as regiões do nosso hemisfério.

Pode-se conhecê-la facilmente por três grandes escamas que lhe cobrem a última falange de cada dedo.

É de cor muito escura, maior e diversa do gavião morto na Cantareira ${ }^{75}$.

Peças consideradas de valor "histórico" também eram visadas, como uma bala que feriu Francisco Solano López, presidente do Paraguai, durante a guerra travada com o Brasil76. Era comum que objetos curiosos fossem parar nas coleções do coronel, tanto do reino vegetal luma casca de jacarandá que apresentava "notável" similaridade com um rosto humano deformado por enfermidades e que foi colorido)77; quanto "monstruosidades" do reino animal, como uma galinha de quatro pernas vinda de Sorocaba e um frango de quatro pernas "armadas de unhas e esporas" de Brotas e que só andava com as pernas dianteiras ${ }^{78}$; além de curiosidade postal (um carta com carimbos de vários lugares do Brasil|79.

É interessante notar que Alberto Loefgren enviou circular aos jornais fazendo pedido semelhante ao que Sertório realizou anteriormente, quando se tornou diretor interino do Museu do Estado em 1891, em que apelava a todos os "que se interessavam pelas ciências e história paulistas" que enviassem objetos de "nossos indígenas ou nossa história" para serem expostos junto às coleções do antigo Museu Sertório, e servir de "instrução para a mocidade estudantil e admiração dos estrangeiros que nos visitam" ${ }^{\prime \prime}$.

Com isso, o Museu continuou a ser procurado por interessados em conceder objetos para fazerem parte do acervo do estabelecimento, inclusive os de origem internacional, como uma armadura de guerreiro japonês ${ }^{81}$, um ídolo dos antigos índios quito, uma medalha em celebração a Simon Bolívar, 11 pedras negras (silicoses) pertencentes a um mosaico da llha de Titicaca, na Bolívia, fragmentos de uma das pedras que acompanham o muro de um templo de São Domingos, na cidade de Cuzco, Peru ${ }^{82}$, cinta feita de incum com sementes e pequenas conchas provenientes do Grão-Chaco ${ }^{83}$

As compras ficaram cada vez mais ambiciosas, ainda na época de Sertório, que investia em objetos custosos:

Museu Sertório - Este incansável cavalheiro que já nas suas salas reuniu o que esta província possui dos reinos mineral e vegetal e animal, quer reunir ainda mais riquezas de outra procedência e pode-se com verdadeiro prazer notar como cada dia suas coleções aumentam graças à insaciável vontade de completá-las, não hesitando diante
75. Cf. Correio Paulistano

(19 nov. 1886, p. 2).

76. Cf. A Provincia de $S$ Paulo (24 jun. 1886, p. 2).

77. Cf. A Provincia de $S$ Paulo (15 ago. 1888, p. 1).

78. Cf. Correio Paulistano (11 abr. 1888, p. 2)

79. Ver O Estado de S. Paulo (22 maio 1890 , p. 1)

80. Cf. O Estado de S. Paulo (14 abr. 1891, p. 2).

81. Ver O Estado de S. Paulo (02 ago. 1891, p. 2).

82. Ver O Estado de S. Paulo (07 ago. 1891, p. 2).

83. Ver O Estado de S. Paulo (22 dez. 1891, p. 2). 
84. Cf. A Provincia de $S$. Paulo (10 jun. 1884, p. 1).

85. Ver O Estado de S. Paulo (05 fev. 1892, p. 1).

86. Cf. A Provincia de $S$. Paulo (08 jul. 1884, p. 1).

87. Ainda não se sabe como J. P. da Motta Junior entrou em contato com o Coronel Sertório, e como este foi contratado para ser naturalista viajante do Museu. No entanto, o que se sabe é que J. P. da Motta Junior era redator do Rio Branco de Pirassununga, sendo ele mesmo um colecionador, como demonstrou a notícia de A Provincia de S. Paulo (04 mai. 1886), em que Motta Junior oferece ao Museu Sertório "entre outros espécimes curiosos um fóssil". Analisando a cronologia das notícias, é possível perceber que ele passou a trabalhar assiduamente para o Museu a partir da segunda metade de 1886 , provavelmente após fazer a doação supracitada. No Primeiro Relatório do Museu do Estado, Hummel, ao descrever a série de Madeiras e Cipós indica que "Infelizmente honrosa exceção feita da coleção Motta Junior, a maior parte [das peças que compõem a sériel vem com nomes lanhamente estropiadas e quase ilegíveis (...)", grifos meus.

88. Cf. Correio Paulistano (05 out. 1886, p. 1).

89. Cf. O Paiz (27 set. 1886 , p. 1).

90. Cf. Correio Paulistano (07 nov. 1886, p. 1). das fadigas das viagens, despesas e, sentimos dizê-lo, diante do pouco apreço dos seus concidadãos que não compreendem o que há de generoso neste modo de empregar uma vida e fortuna em prol da ciência e sem o mínimo interesse ou recompensa.

Ainda no sábado, recebeu este cavalheiro, vindos da Europa, a fim de serem expostos no museu, 5 grandes caixões, contendo: girafa, camelo, leão e muitos outros animais cheios, da Europa, da África, da Ásia e da Austrália; vários esqueletos de quadrúpedes, pássaros, anfíbios, cobras e até peixes - trabalhos admiráveis pela sua extrema delicadeza e alto valor científico; linda coleção de minerais e outra de fósseis para comparação e estudo dos fósseis brasileiros; e o mais perfeito, o mais interessante, um completo cadáver humano de 'papier maché' com as suas cores naturais e composto de maneira a se poder tirar e colocar outra vez todos os músculos e todos os órgãos interiores, tanto do peito como do ventre, sendo só o cérebro composto de 4 partes e até o crânio cortado longitudinalmente para poder-se estudar à vontade $(. . .)^{84}$.

Loefgren, como diretor interino do Museu do Estado, também não deixou de adquirir peças de alto valor, como um esqueleto de baleia ${ }^{85}$

$\bigcirc$ coronel realizava ainda expedições pela província a fim de coletar peças importantes, como os sambaquis:

"Expedição científica - Por estes dias, o coronel Joaquim Sertório, o infatigável proprietário do museu do mesmo nome, parte para S. Vicente para explorar uns Sambaquis, de que há pouco teve notícia e que, segundo afirmam os informantes, devem ser ainda intactos $(\ldots)^{86}$

Museu Sertório chegou a contratar um naturalista viajante, J. P. da Motta Junior ${ }^{87}$, que realizava viagens pelo país, com o intuito de coletar objetos raros para serem expostos. As suas andanças pelo país apareciam, às vezes, nos jornais: "Parte hoje para a corte o sr. J.P. da Motta Junior, naturalista viajante do Museu Sertório"88; o mesmo acontecia com suas descobertas e aquisições, que eram das mais variadas:

Sabe-se em S. Paulo por telegrama do Sr. Motta Junior, transmitido de Jundiaí, que aquele senhor acaba de obter para o Museu Sertório, do qual é colecionador viajante, a cama do padre Feijó e três cadeiras do padre Galvão ${ }^{89}$.

Chegaram ontem ao Museu Sertório três enormes xilólitos, que provavelmente pertencem à família das coníferas, encontrados e enviados pelo naturalista sr. Motta Junior em sua última excursão feita ao sul da província90.

Para o museu Sertório, de S. Paulo, foi enviada do Tietê pelo cidadão Motta Junior, uma rocha de espécie muito rara e curiosíssima.

Esta rocha, que pesa a bagatela de 1.170 quilos [sic] (78 arrobas), é um interessante conglomerado de nódulos de diversas formas e cores vivas, embutidos numa argamassa argilosa e pálida, o que the dá o magnífico aspecto de um primoroso mosaico. 
Os nódulos, que são de natureza diversa e de variadas cores, correndo a escala desde o cristal branco (quartzo), a pedra de fogo preta (sílex), se acham dispostos com tal simetria que o conglomerado parece mais ser obra feita pela mão do homem que um produto da magna natureza. Referindo-se a esse espécime, diz o sr. Motta Junior o seguinte: "Percorrendo quase toda a província, visitando e examinando suas principais pedreiras, só no vale do Tietê me foi permitido deparar com essa interessante rocha, que constitui um dos mais belos espécimes da coleção geológica do Museu Sertório.

Posso garantir que não é conhecido em toda a província lugar que se possa encontrar rocha de natureza e aspecto idênticos ao da amostra que para aí envio"91.

Em sua última excursão ao interior da província, o sr. J. P. da Motta Junior, naturalista viajante do museu Sertório, encontrou nas matas e campos do município de Jaboticabal duas espécies interessantes da nossa riquíssima flora, uma da família das euforbiáceas, que produz leite da consistência e análoga à borracha da seringueira (syphoniaelastica) e outra da família da frascinelas (gênero dictamus albus), que segrega uma resina nos meses de Julho a Setembro, muito semelhante na cor, no gosto e nas propriedades terapêuticas ao maná que importamos do estrangeiro e principalmente da ltália92.

\section{TESOURO}

O sr. Motta Junior, naturalista viajante do Museu Sertório, enviou-nos ontem, do Tietê, o seguinte telegrama:

"Descobri tesouro em Pinheiros.

Obtive concessão do proprietário para fazer a respectiva exploração"93.

Motta Junior servia também como intermediário entre doadores e o Coronel Sertório: "(...) o sr. Aureliano de Souza e Oliveira oferece ao sr. Motta Junior diversos objetos interessantes para o Museu Sertório (...)"94.

Sertório, portanto, formou sua coleção adquirindo ele mesmo as peças, realizando expedições para coletar outros itens de interesse científico - chegou até a ter um profissional especializado em fazer esse tipo de viagem - e recebendo ofertas de indivíduos em geral.

Quanto à localização do Museu Sertório, constatou-se que possuiu dois endereços diferentes. $\bigcirc$ primeiro situava-o na rua do Imperador, próximo ao largo Municipal (atual praça João Mendes) ${ }^{95}$, como informa Lomonaco ${ }^{96}$. Esse endereço é confirmado na imprensa: "O estimável paulista fez o que se obrigara: lá se acham no seu museu à rua do Imperador esses espécimes. (...)"97. Com a Proclamação da República, essa rua passou a se chamar Marechal Deodoro ${ }^{98}$.

Raffard visitou as coleções em um espaço diferente, localizado no largo Municipal, ou largo da Assembleia, n. 27 (no que hoje seria a praça João Mendes ${ }^{99}$. Em 17 de maio de 1889, A Provincia de S. Paulo reportou que "devese inaugurar no próximo mês de junho" o Museu Sertório, indicando que o estabelecimento ficou fechado por um tempo até abrir em uma nova sede ${ }^{100}$. Outras notícias também confirmaram o novo endereço: "A quermesse se realizará no vasto
91. Cf. O Paiz (09 dez. 1886, p. 1).

92. Cf. Correio Paulistano (11 jan. 1887, p. 2).

93. Cf. Correio Paulistano (12 mar. 1887, p. 2).

94. Cf. A Provincia de $S$. Paulo (24 jun. 1886, p. 2), grifos meus.

95. "Estava este museu instalado no antigo largo $\mathrm{Mu}$ nicipal, boje praça João Mendes, naquela Capital, no prédio atualmente ocupado pela Biblioteca Pública do Estado" (grifos meus), Cf. Francisco de Paula Mayrink Lessa (1975, p. 184).

96. Ver Alfonso Lomonaco (1889, p. 121).

97. Cf. A Provincia de $S$ Paulo (13 nov. 1884, p. 1) grifos meus.

98. No início do século XX, essa rua deixou de existir, assim como a rua Esperança, para ampliar a praça da Sé, durante a gestão do $\mathrm{Ba}$ rão de Duprat.

99. Ver Henrique Raffard (1977 [1890], p. 86).

100. Cf. A Provincia de $S$. Paulo (17 maio 1889, p. 1). 
101. Cf. O Estado de S. Paulo (05 dez. 1891, p. 2), grifos meus.

102. Cf. O Estado de S. Paulo (01 jan. 1891, p. 1), grifos meus.

103. Cf. Alfonso Lomonaco (1889, p. 121).

104. Cf. Henrique Raffard (1977, p. 87).

105. Arquivo do Estado de São Paulo (Livro de Outorgas $\mathrm{n}^{\circ} 82,1890, \mathrm{E} 12137$, p. 189).

106. Idem (p. 190). Essa quantia não significa necessariamente que as coleções realmente valessem mais que o edifício. Poderia ser, na verdade, uma forma de o comprador pagar uma tarifa menor no ato da aquisição, uma vez que o imposto sobre o registro do imóvel constava ser de $6 \%$ sobre o valor pago para adquirir o imóvel, enquanto que o valor de registro do Museu era de $5 \%$. Ou seja, é possível que vendedor e comprador tenham fechado um valor total pelas duas compras, que foi dividido de forma a se pagar o menor valor de expensas cartoriais. Nesse caso, era mais econômico registrar um custo mais elevado para o museu em relação ao edifício.

107. Cf. O Estado de S. Paulo (18 jul. 1890, p. 1; 19 jul. 1890, p. 1; 01 ago. 1890, p. 1) e Correio Paulistano $(02$ ago. 1890 , p. 2). salão do antigo Museu Sertório, largo Municipal, n 27 (...)"101; "Por não ter podido aproveitar o salão da Pauliceia, (...) o pintor Antonio Parreiras expôs ontem no pavimento térreo da casa onde foi o Museu Sertório, largo Municipal n ${ }^{\circ} 27$ $(\ldots)^{\prime \prime} 102$.

É interessante notar como a descrição do prédio em que se encontravam as coleções é distinta entre os visitantes. Lomonaco, que empreendeu sua visita em 1886, explicou que a coleção se encontrava no andar térreo de uma residência particular, "muito restrito para as coleções que abriga" e, por isso, defendia que elas seriam mais bem apreciadas em "lugar mais amplo e melhor iluminado"103. Raffard, que visitou o museu em 1890, embora fizesse queixas sobre o estado dos objetos, mostrou-se satisfeito com o local onde estavam expostas as peças: "o vasto local tem contudo excelente aspecto, sendo bem claro e arejado, com novas vitrinas fechadas onde se nota assaz boa ordem"104. Essas comparações são outro indício de que o Museu Sertório havia mudado de edifício.

Foi o prédio visitado por Raffard que foi comprado - junto com a coleção Sertório - pelo conselheiro Francisco de Paula Mayrink. Essa compra foi realizada oficialmente em 29 de outubro de 1890, no $2^{\circ}$ Cartório de Notas da Capital. O imóvel estava no nome do coronel Joaquim Sertório e no de sua mulher, Maria Ribas Sertório, e o conselheiro, domiciliado no Rio de Janeiro, foi representado por seu procurador, o comendador Manuel Teixeira Silva Cotta; a propriedade foi vendida por 100 contos de réis. $\bigcirc$ documento confirmou o endereço do edifício como largo Municipal, n. 27,

(...) junto à Igreja de Nossa Senhora dos Remédios, freguesia de Nossa Senhora d'Assunção da Sé, município e comarca da Capital, Estado de São Paulo; dividido por um lado com a lgreja de Nossa Senhora dos Remédios, por outro com o prédio do Mosteiro de São Bento, e pelos fundos com a rua do Quartel (...) $)^{105}$.

A compra do acervo do Museu Sertório, realizada no mesmo dia 29 de outubro de 1890, também consta na documentação do $2^{\circ}$ Cartório da Capital. Os "objetos de zoologia, mineralogia, arqueologia, os que fazem parte da coleção conhecida pelo nome de - Museu Sertório" tinham o Coronel Sertório como único proprietário, e foram vendidos ao conselheiro sob a representação do mesmo procurador. É curioso notar que a coleção foi vendida a um preço mais alto que o imóvel, 150 contos de réis ${ }^{100}$. Mayrink dispendeu, portanto, no total, 250 contos de réis na aquisição do prédio e da coleção.

Os acontecimentos que antecederam a compra, em 1890, giravam em torno de notícias que informavam que a coleção Sertório, logo depois de ser reaberta em novo endereço, seria "alienada para o estrangeiro". O museu seria vendido a José Teixeira Braga Junior, capitalista brasileiro, residente na cidade do Porto, tendo como intermediário Antonio Pereira de Mello ${ }^{107}$. A imprensa, perplexa diante da notícia, defendia que o Museu Sertório permanecesse em São Paulo, devendo "ser propriedade do estado, para instrução do público e documento de 
progresso, que possa ser mostrado, com orgulho, aos estrangeiros que nos visitem"108. Ou seja, o governo deveria adquirir o museu.

Em resposta, Joaquim Sertório escreveu que

(...) estimaria bastante que o governo do Estado, a cuja frente se acha um paulista tão ilustre como patriota [o governador nomeado Prudente de Moraes], fizesse dele aquisição.

Estou pronto a dar essa notável coleção de preciosidades pelo preço que me tem custado sem lucro absolutamente algum, o que só parece ser alguma generosidade de minha parte ${ }^{109}$.

Para alívio geral, de acordo com os jornais, o conselheiro Francisco de Paula Mayrink adquiriu por "250 contos de réis" o Museu Sertório, junto com o prédio em que se encontrava instalado, a fim de oferecê-lo ao governo paulista ${ }^{110}$.

Mayrink também pediu à Comissão do lpiranga que o museu fosse transferido para o Monumento do lpiranga ${ }^{11}$. A oferta de doação da coleção ao governo estadual foi realizada por Mayrink por meio de um ofício, explicitando a sua vontade de que o Museu Sertório fosse abrigado no edifício do lpiranga ${ }^{112}$. Foi em dezembro de 1890 que o Museu Sertório passou oficialmente ao governo, que ainda considerava comprar o prédio ${ }^{13}$ em que se encontrava a coleção e que foi adquirido por Mayrink ${ }^{114}$.

As motivações da doação de Mayrink ainda não estão claras. Em Vida e obra do Conselheiro Mayrink, escrito pelo neto do conselheiro, Francisco de Paula Mayrink Lessa descreveu a aquisição do Museu Sertório, começando com a compra da coleção Pessanha ${ }^{15}$. Para ele, seu avô doou o Museu Sertório ao Governo de São Paulo para "engrandecer" a cidade com um museu oficial, algo que toda grande metrópole deveria possuir. E mesmo não sendo paulista de nascimento - e sim fluminense -, ele era brasileiro. $\bigcirc$ autor ainda lamentou a falta de reconhecimento de Mayrink como fundador do Museu Paulista. Para consertar essa falha, sugeriu que a estátua equestre do conselheiro fosse colocada no Salão de Honra do Museu, como homenagem tardia ao "precursor" da instituição ${ }^{116}$.

Após a doação, segundo contou Orville Derby, o presidente da Comissão Geográfica e Geológica no período em que o Museu Sertório passou ao governo, a casa com as coleções ficou fechada por alguns meses "devido à indecisão por parte do governo sobre qual destino dar ao prédio e ao acervo" 117. $\bigcirc$ destino do Museu só seria decidido em abril, quando foi nomeado Alberto Loefgren como diretor interino ${ }^{118}$. De acordo com ato publicado no Correio Paulistano, uma lista com os objetos do Museu Sertório chegou às mãos do Governo Estadual, que a enviou a Loefgren ${ }^{119}$. A trajetória subsequente foi narrada pelo então presidente da Comissão Geográfica e Geológica, Orville Derby:

Na lei de orçamento votada em 1892 para o exercício de 1893 o Museu foi anexado à Comissão Geográfica e Geológica, e em Janeiro deste último ano cessou a sua
108. Cf. O Estado de S. Paulo (19 jul. 1890, p. 1).

109. Cf. O Estado de S. Paulo (17 ago. 1890 , p. 2).

110. Cf. O Estado de S. Paulo (25 set. 1890 , p. 1$)$.

111. Ver O Estado de S. Paulo (22 out. 1890, p. 1) e Correio Paulistano (22 out. 1890, p. 1).

112. Ofício de Francisco Mayrink ao Governador do Estado de São Paulo em Arquivo do Estado de S. Paulo (01/11/1890, Série Ofícios Diversos). Nesse documento, há uma anotação escrita na parte superior esquerda que parece ser um lembrete para responder à oferta: "Para agradecer - Respondeu-se agradecendo a 2112-90", cf. O Correio Paulistano (03 jan. 1891, p. 2) divulgou que "o dr. governador dirigiu um ofício ao conselheiro Mayrink declarando aceitar e agradecendo a valiosa oferta que fez ao Estado da coleção de objetos de história natural existentes no antigo Museu Sertório".

113. Uma informação retirada do livro Vida e obra do Conselbeiro Mayrink de Francisco P. M. Lessa (1975, p. 184), lança pistas sobre o destino do prédio, mostrando que o governo o teria adquirido em algum momento, tendo sediado a Biblioteca Pública do Estado de São Paulo: "Existia em São Paulo uma coleção particular de visita pública e gratuita a que se dava o nome de 'Museu Sertório'. Pertencia ao antiquário coronel Joaquim Sertório. / Estava este museu instalado no antigo largo Municipal, hoje praça João Mendes, naquela Capital, no prédio atualmente ocupado pela Biblioteca Pública do Estado" (grifos meus).

114. Ver O Estado de S. Paulo (25 dez. 1890, p. 1). 
115. Ainda não existem informações precisas sobre a coleção Pessanha, mas pela documentação pesquisada foi possível descobrir que era um acervo menor que o do Museu Sertório, e do qual constava um herbário. É possível que o proprietário fosse Antonio Lobo Peçanha, que foi um dos diretores da Sociedade Auxiliadora do Progresso, fundadora do Museu Provincial, em 1877.

116. Cf. Francisco P. M. Lessa (1975, p. 184-186).

117. Ofício de Orville Derby ao cidadão Dr. Hermann von Ihering, Revista do $\mathrm{Mu}$ seu Paulista, 1895, p. 13. Esse trecho do documento deixou a entender que Mayrink teria doado o prédio ao governo do Estado de São Paulo.

118. Ver O Estado de S. Paulo (08 abr. 1891, p. 1) e Correio Paulistano (08 abr. 1891, p. 2).

119. Ver Correio Paulistano (08 abr. 1891, p. 2).

120. Cf. Ofício de Orville Derby ao cidadão Dr. Hermann von Ihering, Revista do Museu Paulista, 1895, pp. 13-14. administração provisória, ficando seu pessoal incorporado com o da Comissão Geográfica e Geológica.

No entanto tinha o Governo procurado entender-se com o proprietário do prédio ocupado pelo Museu a fim de alugá-lo por conta do Estado, sem sequer obter resposta; instado, pelo contrário, os representantes do proprietário nesta Cidade para a desocupação imediata do prédio. Não se encontrando na ocasião outro prédio para alugar que pudesse servir para a instalação do Museu, as coleções foram em princípios de Dezembro de 1892 removidas para uma casa no largo do Palácio, o qual o Governo desapropriara para ser demolida. A final de Março de 1893 encontrou o Governo e alugou à Rua da Consolação n. 91, um prédio em condições de servir para o duplo fim de escritório da Comissão e para o Museu: e assim as coleções foram instaladas no referido prédio.

Tendo aceitado a responsabilidade do Museu com grande relutância e em obediência à lei que fora votada sem eu ser consultado e sem fazer provisão para o desenvolvimento conveniente do Museu, esbocei um plano para coordenar e desenvolver modestamente à sombra da Comissão Geográfica e Geológica, que tinha a seu cargo diversos serviços que podiam contribuir para várias seções de um Museu de História Natural, notadamente as de Geologia, Mineralogia e Botânica. Sendo-me oferecida a cooperação de um zoologista de grande nome, aproveitei o ensejo para completar o programa de um verdadeiro museu propondo ao governo a criação de uma seção zoológica nesta Comissão - proposta que foi aceita, sendo-vos confiada a direção da nova seção que foi iniciada em Maio de 1893

Logo depois o Congresso do Estado determinou criar no monumento do Ypiranga um museu independente, e no princípio do exercício de 1894 cessou a ligação provisória do Museu com a Comissão Geográfica e Geológica, passando para o novo estabelecimento o pessoal da seção zoológica desta. Saúde e fraternidade.

Ao cidadão Dr. Hermann von Ihering, M. D. Diretor do "Museu Paulista".

Orville Derby ${ }^{120}$.

Em suma, o presente artigo apresentou elementos novos sobre o Museu Sertório, tanto com relação aos objetos que compunham a coleção quanto sobre a sua formação e sua localização na cidade de São Paulo. Esta pesquisa possibilitou, assim, perceber suas similaridades com o modelo do gabinete de curiosidades moderno europeu, demonstrando certas continuidades no campo do colecionismo entre a Europa moderna e a São Paulo do século XIX, momento em que os museus nacionais do Novo Mundo estavam sendo organizados. 
ALVES, Ana Maria de Alencar. O Ipiranga apropriado: ciência, política e poder (o Museu Paulista, 1893-1922). São Paulo: História Social USP/ Humanitas, 2001. (Série Teses).

BREFE, Ana Claudia Fonseca. O Museu Paulista: Affonso de Taunay e a memória nacional. São Paulo: Editora UNESP/ Museu Paulista, 2005.

BURKE, Peter. Qualche riflessione sull'antropologia storica del collezionismo. In: AIKEMA, Bernard; LAUBER, Rosella; SEIDEL, Max (org.). Il collezionismo a Venezia e nel Veneto ai tempi della Serenissima. Venezia: Marsilio Editori, 2005. p. 51-54.

ELIAS, Maria José. Museu Paulista: Memória e história. 1996. 2v. Tese (Doutorado em História) - Departamento de História da Faculdade de Filosofia, Letras e Ciências Humanas, Universidade de São Paulo, São Paulo, 1996.

FRANÇOZO, Mariana. O Museu Paulista e a história da antropologia no Brasil entre 1946 e 1956. Revista de Antropologia, São Paulo, p. 586-612, 2005.

GROLA, Diego Amorim. Coleções de História Natural no Museu Paulista, 1894-1916. Dissertação (mestrado) - Faculdade de Filosofia, Letras e Ciências Humanas, São Paulo, 2014.

KENSETH, Joy. The age of the marvelous: an introduction. In: KENSETH, Joy (ed.). The age of the marvelous. Hanover (NH): Dartmouth College/ Hood Museum of Art, 1991. [Catálogo de exposição].

KOSERITZ, Carl von. Imagens do Brasil. Belo Horizonte: Itatiaia; São Paulo: EDUSP, 1980. (Reconquista do Brasil; nova série; v. 22). [1ª ed. 1883].

LESSA, Francisco de Paula Mayrink. Vida e obra do Conselheiro Mayrink (completada por uma genealogia da família). Rio de Janeiro: Pongetti, 1975.

LOMONACO, Alfonso. Al Brasile. Milano: Dott Leonardo Villardi Edit, 1889.

LOPES, Maria Margaret. O Brasil descobre a pesquisa científica: os museus e as ciências naturais no século XIX. São Paulo: Hucitec, 1997.

LOPES, Maria Margaret; FIGUEIRÔA, Silvia Fernanda de Mendonça. A criação do Museu Paulista na correspondência de Hermann von Ihering (1850-1930). Anais do Museu Paulista: História e Cultura Material, São Paulo, v. 10-11, n. 1, p. 23-35, 2003.

MAKINO, Miyoko. Cronologia do Museu Paulista/USP. Diário Oficial do Estado de São Paulo, São Paulo, v. 107, n. 220, 15 nov. 1997.

MENESES, Ulpiano T. Bezerra de. Do teatro da memória ao laboratório da História: a exposição museológica e o conhecimento histórico. Anais do Museu Paulista: História e Cultura Material, São Paulo, v. 2, n. 1, p. 9-42, 1994. 
MORAES, Fábio Rodrigo. Uma coleção de história em um museu de ciências naturais: o Museu Paulista de Hermann von Ihering. Anais do Museu Paulista: História e Cultura Material, São Paulo, v. 16, n.1, p. 203-233, jan.-jun. 2008.

MOURA, Carlos Eugênio Marcondes de (org.). Vida cotidiana em São Paulo no século XX. São Paulo: Ateliê Editorial/ Fundação Editora da Unesp/ Imprensa Oficial do Estado/ Secretaria de Estado da Cultura, 1998.

RAFFARD, Henrique. Alguns dias na Pauliceia. São Paulo: Academia Paulista de Letras, 1977. (Biblioteca Academia Paulista de Letras, 4). [1 ${ }^{\mathrm{a}}$ ed. 1890].

SCHNAPPER, Antoine. Le géant, la licorne, la tulipe: collections et collectionneurs dans la France du XVIIe siècle. Paris: Flammarion, 1988.

SCHWARCZ, Lilia Moritz. O espetáculo das raças: cientistas, instituições e questão racial no Brasil, 1870-1930. São Paulo: Companhia das Letras, 2007. [1 $1^{\mathrm{a}}$ ed. 1993].

SEVCENKO, Nicolau. Museu Paulista: História, Mito, Critica. In: Às margens do Ipiranga: 1890-1990. São Paulo: Museu Paulista/USP, 1990.

SILVA, Tathianni Cristini da. Homem de Letras, homem de História: Mário Neme, um intelectual de transição. Dissertação (mestrado) - Faculdade de Filosofia, Letras e Ciências Humanas, São Paulo, 2011. 